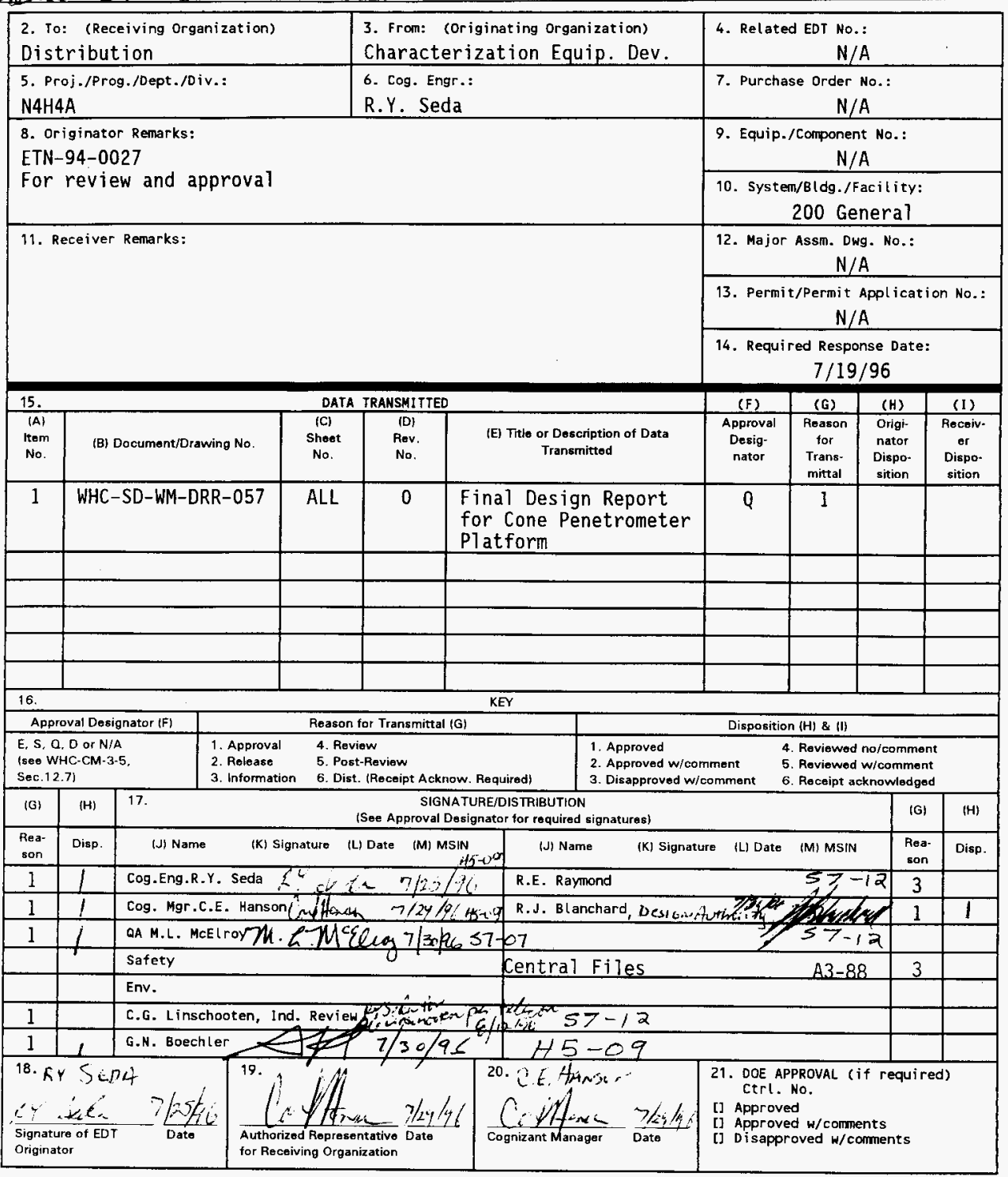

BD-7400-172-2(04/94) GEF097 


\section{Final Design Report for Cone Penetrometer Platform}

\section{R. Y. Seda}

WHC, Richland, WA 99352

U.S. Department of Energy Contract DE-ACO6-87RL10930

$\begin{array}{lll}\text { EDT } / \text { ECN: } & 140822 & \text { UC: } 2070 \\ \text { Org Code: } & 75250 & \text { Charge Code: N4H4A } \\ \text { B\&R Code: } & \text { EW3120074 } & \text { Total Pages: } 84\end{array}$

Key Words: Cone Penetrometer Platform, Final Design Report

Abstract: The final design report documents the completion of the design review meetings for acceptance of the cone penetrometer from the vendor. All design comments have been dispositioned and closed. Open items dealt with completion of the safety assessment, operational procedures, operational testing and readiness review.

TRADEMARK DISCLAIMER. Reference herein to any specific commercial product, process, or service by trade name, trademark, manufacturer, or otherwise, does not necessarily constitute or imply its endorsement, recommendation, or favoring by the United States Government or any agency thereof or $i$ ts contractors or subcontractors.

Printed in the United States of America. To obtain copies of this document, contact: WHC/BCS Document Control Services, P.O. Box 1970, Mailstop H6-08, Richland WA 99352, Phone (509) 372-2420; Fax (509) 376-4989.
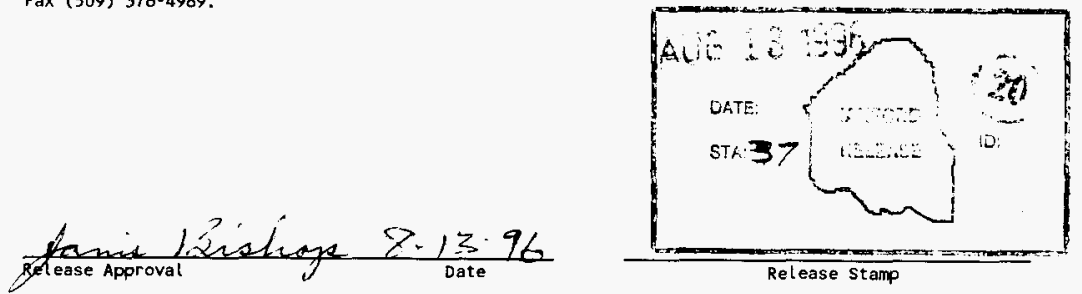

\section{Approved for Public Release}




\section{FINAL DESIGN REPORT}

FOR

\section{CONE PENETROMETER PLATFORM}

Issued by:

R.Y. Seda

Tank Waste Remediation System Characterization Project 
WHC-SD-WM-DRR-057

Rev 0

Page 2 of 10

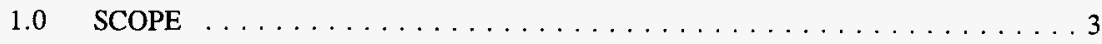

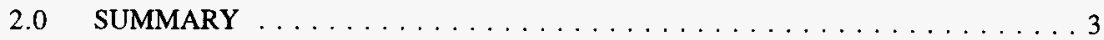

3.0 GENERAL DESIGN DESCRIPTION $\ldots \ldots \ldots \ldots \ldots \ldots \ldots$

$4.0 \quad$ REVIEW DOCUMENTS $\ldots \ldots \ldots \ldots \ldots \ldots \ldots \ldots \ldots \ldots \ldots$

5.0 REVIEW COMMENTS RECORDS $\ldots \ldots \ldots \ldots \ldots \ldots \ldots$

6.0 CONCLUSIONS AND OPEN ITEMS $\ldots \ldots \ldots \ldots \ldots \ldots \ldots$

7.0 DOCUMENTATION $\ldots \ldots \ldots \ldots \ldots \ldots \ldots \ldots \ldots \ldots \ldots \ldots \ldots \ldots$

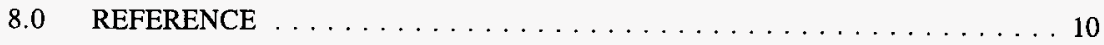

Appendix A: $100 \%$ Design Review $\ldots \ldots \ldots \ldots \ldots \ldots \ldots \ldots \ldots$ A

Appendix B: $60 \%$ Design Review $\ldots \ldots \ldots \ldots \ldots \ldots \ldots \ldots$

Appendix C: $30 \%$ Design Review $\ldots \ldots \ldots \ldots \ldots \ldots \ldots \ldots \ldots \ldots$ 
WHC-SD-WM-DRR-057

Rev 0

Page 3 of 10

\section{$1.0 \quad$ SCOPE}

The design review strategy for the Cone Penetrometer Program, is to utilize the independent review form of the design verification, per WHC-CM-6-1, Standard Engineering Practices (EP 4.1 Design Verification). Several design review sessions were held at approximately the $30 \%, 60 \%$ and $100 \%$ phases of the cone penetrometer design, to brief the independent reviewers, and to solicit their comments. A system design review will be performed once the safety assessment is complete. Attached are the meeting minutes and RCR's from the reviews, which show the acceptability of the design from the cone penetrometer vendor (reference Purchase Requisition 357153).

The object of these reviews is to provide design verification to insure equipment function, personnel safety, and compliance with WHC-CM-6-1, Standard Engineering Practice and Performance Specification WHC-S-0241.

\subsection{SUMMARY}

An independent design review committee was selected in accordance with EP 4.1. A design review was performed at $30 \%, 60 \%$ and $100 \%$ levels. The final design review was held on June 5, 1996.

Due to schedule and budget constraints, design and fabrication were completed concurrently. The reviews were scheduled to accommodate the parallel work schedule. For example, the $30 \%$ design review, the overall system was examined with an in-depth review of the substructure which was the first item fabricated. All fabricated equipment had to be approved by WHC. The vendor design approval packages were included in the design reviews.

The final review examined the penetrometer platform design, hardware integration of the Raman spectroscopy system, and hardware and software integration of the moisture probe to the platform. The standard sensor package, bottom detection sensor, Raman probe, consoles, support trailer, guide tube, push rods, hydraulics, safety logic, operational ergonomics and all other vendor supplied equipment was included in the final review. All design comments, relating to WHC-S-0241, have been dispositioned and closed. Most open items dealt with completion of the safety assessment or the operational readiness review. The moisture probe meets the requirements in functional design criteria, WHC-SD-WM-FDC-047, as indicated in WHC-SD-WM-ATR-145. Based on these reviews, the vendor design has been accepted. 


\subsection{GENERAL DESIGN DESCRIPTION}

The cone penetrometer is a hydraulically driven instrumented rod which is pushed into the waste and measures chemical and physical properties in situ. The rod is supported by a guide tube which provides structural support to the rod. The rod is assembled by screwing rod sections into a instrumented tip as the rod is pushed into the waste.

The following properties are measured:

\section{Physical Properties:}

Yield Strength

Shear Strength

Compressive Strength

Stratigraphy

\section{Chemical Properties:}

Species Identification

Relative Concentration

\author{
Surface Moisture \\ Full Moisture Content Profile \\ Temperature Profile \\ Water Level
}

A detailed design description of the cone penetrometer platform and the moisture probe are located in WHC-SD-WM-SDD-062 and WHC-SD-WM-SDD-063.

\subsection{REVIEW DOCUMENTS}

Vendor (ARA) drawings were reviewed. The major assemblies examined included:

$\begin{array}{ll}\text { HO53-1A } & \text { Platform Top Assembly } \\ \text { HO00-4A } & \text { Push System Assembly } \\ \text { HO52-2A } & \text { Platform Subframe Assembly } \\ \text { HO43-5A } & \text { Cone Assembly, 2.00 Piezo } \\ \text { HO59-3A } & \text { Skid Electrical Distribution Panel } \\ \text { HO61-3A } & \text { Body Van } \\ \text { HO77-6A } & \text { Trailer Assembly }\end{array}$

\subsection{REVIEW COMMENTS RECORDS}

The following table is a listing of reviewers for the $30 \%, 60 \%$ and $100 \%$ design reviews. All generated RCR's were dispositioned and signed off as closed, except for sections which were left as open items. A copy of each dispositioned RCR and opened RCR are 
WHC-SD-WM-DRR-057

included as attachments of this report.

Reviewer

L.S. Krogsrud

D.J. Foust

M.E. Nolen

J.E. Kane

J.K. Bajwa

G.R. Bloom

R.L. Hand

P.W. Gibbon

F.M. Jones

J.H. Bussell

J.M. Silko

P.R. Hernandez

F.A. Jensen

P.R. Diechelbohrer

C.G. Linschooten

G.N. Boechler

C.E. Hanson

R.Y. Seda

R.E. Raymond

M.L. McElroy

L.D. Draper

F.G. Abatt

J.P. Strehlow

R.L. Butler

T.R. Thomas

\section{Discipline}

Safety

Safety/Radiation Control

Safety

Safety/Radiation Control

Safety Assessment

Retrieval

Retrieval

Retrieval

Electrical Equipment

NEC Compliance

DOE-RL

DOE-RL

MacTec

Characterization Equipment Design

Characterization Equipment Design

Characterization Equipment Development

Characterization Equipment Development

Characterization Equipment Development

Characterization Equipment

Quality Assurance

Operations

Stress Analysis

Stress Analysis

Procurement

INEL

\subsection{CONCLUSIONS AND OPEN ITEMS}

The following open items were noted during the design review but were outside the scope of the performance specification. These items shall be addressed and closed when funds are available. When funds become available, the Safety Assessment, Operational Procedures, Operational Test Procedure and Readiness Review efforts will be initiated. The activities will close all the outstanding unclosed issues from the operations design reviews. The responsible person to close the open issues is noted in the attached table.

All open RCR items are either related to operating procedures or possible changes due to the Safety Assessment. None of the open items were related to the design adequacy of 
meeting the performance specification.

OPEN ISSUES:

Final Design

\begin{tabular}{|l|l|l|l|}
\hline & Reviewer & Description & $\begin{array}{l}\text { Responsible } \\
\text { Person }\end{array}$ \\
\hline 1 & F. Johansen & $\begin{array}{l}\text { Testing of the Raman optical array for thermal } \\
\text { stability of the optical elements at tank operating } \\
\text { temperatures is needed. }\end{array}$ & K. Kyle \\
\hline 2 & $\begin{array}{l}\text { M.L. McElroy } \\
\text { D.J. Foust } \\
\text { C.G. Linschooten }\end{array}$ & $\begin{array}{l}\text { Wood deck and rails on support trailer are a } \\
\text { radiological control problem. The wood should } \\
\text { be replaced with a non-porous material }\end{array}$ & R.Y. Seda \\
\hline 3 & C.G. Linschooten & $\begin{array}{l}\text { Operating procedures requiring a camera to be } \\
\text { installed in the tank, to prevent overflow at the } \\
\text { washer station, in case of a lollypop on the } \\
\text { penetrometer or guide tube, are needed. }\end{array}$ & R.Y. Seda \\
\hline 4 & C.G. Linschooten & $\begin{array}{l}\text { Step-by-step sequencing of clamping operations } \\
\text { procedure are needed. }\end{array}$ & R.Y. Seda \\
\hline 5 & G.R. Bloom & $\begin{array}{l}\text { The safety assessment needs to be completed as } \\
\text { well as any modifications required by the } \\
\text { assessment. }\end{array}$ & R.Y. Seda \\
\hline 6 & $\begin{array}{l}\text { G.R. Bloom } \\
\text { M.E. Nolen }\end{array}$ & $\begin{array}{l}\text { Operating procedures need to be completed to } \\
\text { assure operability of the design. Procedures } \\
\text { should include tying down the 3000 psi hydraulic } \\
\text { line from the trailer to the platform. }\end{array}$ & R.Y. Seda \\
\hline 7 & $\begin{array}{l}\text { M.M. Silko } \\
\text { J.H. Bloom } \\
\text { to adiation design analysis needs to be completed } \\
\text { operators. }\end{array}$ & $\begin{array}{l}\text { The guide tube shoe anchor could benefit from } \\
\text { the addition of a second wiper, so that a wiper } \\
\text { sandwiches the guide tube. }\end{array}$ & R.Y. Seda \\
\hline
\end{tabular}


WHC-SD-WM-DRR-057

Rev 0

Page 7 of 10

\begin{tabular}{|l|l|l|l|}
\hline & Reviewer & Description & $\begin{array}{l}\text { Responsible } \\
\text { Person }\end{array}$ \\
\hline 9 & M.E. Nolen & $\begin{array}{l}\text { An industrial hygienist needs to examine the } \\
\text { operation of the cone penetrometer to } \\
\text { determine the frequency and location of } \\
\text { atmospheric checks. }\end{array}$ & R.Y. Seda \\
\hline 10 & M.E. Nolen & Seats need to be provided for the operators & R.Y. Seda \\
\hline 11 & J.H. Bussell & $\begin{array}{l}\text { Standard dosimeter will indicate a higher neutron } \\
\text { dose than Hanford Neutron Combo dosimeters. } \\
\text { Equipping personnel around skid with Hanford } \\
\text { Combo Neutron dosimeters is suggested. }\end{array}$ & R.Y. Seda \\
\hline 12 & J.H. Bussell & $\begin{array}{l}\text { Need radiation monitors at washer for gamma } \\
\text { and beta. }\end{array}$ & R.Y. Seda \\
\hline 13 & M.L. McElroy & $\begin{array}{l}\text { Administrative controls are required to keep the } \\
\text { ingress/egress doors to control the work } \\
\text { atmosphere and accessibility of pest. }\end{array}$ & R.Y. Seda \\
\hline 14 & M.L. McElroy & $\begin{array}{l}\text { The transport and storage, both onsite and } \\
\text { offsite, of the neutron source must be thought out } \\
\text { completely, i.e. special handling tools, } \\
\text { procedures, permanent storage, custodial } \\
\text { obligations, etc. }\end{array}$ & R.Y. Seda \\
\hline 16 & M.E. Nolen & $\begin{array}{l}\text { Drip/catch pans maybe required for leakage of } \\
\text { hydraulic fluids on tanks that petroleum base } \\
\text { products are not allowed. }\end{array}$ & R.Y. Seda \\
\hline 17 & C.G. Linschooten & $\begin{array}{l}\text { The drawings do not indicate the ballast filler } \\
\text { material nor weight. }\end{array}$ & R.Y. Seda \\
\hline 15 & M.L. McElroy & $\begin{array}{l}\text { All items to be carried or picked need the weight } \\
\text { to be indicated on the part. }\end{array}$ & R.Y. Seda \\
\hline Cinschooten & $\begin{array}{l}\text { Assembly and subassembly and dimensions of } \\
\text { drawings need to be improved }\end{array}$ & R.Y. Seda \\
\hline 19 & C.G. Linschooten & R.Y. Seda \\
\hline
\end{tabular}




\begin{tabular}{|l|l|l|l|}
\hline & Reviewer & Description & $\begin{array}{l}\text { Responsible } \\
\text { Person }\end{array}$ \\
\hline 20 & G.R. Bloom & $\begin{array}{l}\text { The ATP needs to confirm shear strength } \\
\text { accuracy mets specifications needs be completed } \\
\text { before cone penetrometer delivery. }\end{array}$ & G.N. Boechler \\
\hline 21 & M.E. Nolen & $\begin{array}{l}\text { Need all specifications on the winch and trolley } \\
\text { system. Label trolley for load allowed and load } \\
\text { test it. }\end{array}$ & R.Y. Seda \\
\hline 22 & M.E. Nolen & $\begin{array}{l}\text { Need the height and location of the computer } \\
\text { display monitors for ergonomic concerns. }\end{array}$ & R.Y. Seda \\
\hline 23 & F.M. Jones & $\begin{array}{l}\text { The single line diagram need to show overload } \\
\text { device, output protective device size, cable and } \\
\text { connector size, cable strain relief and seismic } \\
\text { support, grounding detail, DP main breaker and } \\
\text { how heater, pumps and DP heater will operate. }\end{array}$ & R.Y. Seda \\
\hline 24 & F.M. Jones & $\begin{array}{l}\text { Electrical distribution panel needs to identify } \\
\text { fuses. Electrical drawings need to show } 24 \text { V } \\
\text { and 12V power supplies. }\end{array}$ & R.Y. Seda \\
\hline 25 & C.G. Linschooten & $\begin{array}{l}\text { Electrical hookups need to be compatible with } \\
\text { new tank farm hook ups requirements }\end{array}$ & R.Y. Seda \\
\hline 26 & M.L. McElroy & $\begin{array}{l}\text { ATR, when issued, needs all sensor calibration } \\
\text { curves. }\end{array}$ & G.N. Boechler \\
\hline 27 & C.G. Linschooten & \begin{tabular}{l} 
Contractual operations need to be finalized. \\
\hline
\end{tabular} & G.A. Barnes \\
\hline
\end{tabular}

\section{0\% Design}

\begin{tabular}{|l|l|l|l|}
\hline & Reviewer & Description & $\begin{array}{l}\text { Responsible } \\
\text { Person }\end{array}$ \\
\hline 1 & R.E. Raymond & A mission analysis needs to be completed. & R.Y. Seda \\
\hline 2 & C.E. Hanson & Need to plug into TCRs. & R.Y. Seda \\
\hline 3 & C.G. Linschooten & Operational contract issues need to be resolved & R.Y. Seda \\
\hline
\end{tabular}


WHC-SD-WM-DRR-057

Rev 0

Page 9 of 10

\begin{tabular}{|l|l|l|l|}
\hline & Reviewer & Description & $\begin{array}{l}\text { Responsible } \\
\text { Person }\end{array}$ \\
\hline 4 & C.E. Hanson & $\begin{array}{l}\text { Operational procedures need to be developed } \\
\text { which include bagging and rigging procedures. }\end{array}$ & R.Y. Seda \\
\hline 5 & C.E. Hanson & $\begin{array}{l}\text { Dome loading analysis for the cone penetrometer } \\
\text { need to be finalized.. }\end{array}$ & R.Y. Seda \\
\hline 6 & P.R. Diechelbohrer & $\begin{array}{l}\text { QA approval is needed for Raman spectroscopy } \\
\text { neutral network. }\end{array}$ & R.Y. Seda \\
\hline
\end{tabular}

30\% Design

\begin{tabular}{|l|l|l|l|}
\hline & Reviewer & Description & $\begin{array}{l}\text { Responsible } \\
\text { Person }\end{array}$ \\
\hline 1 & $\begin{array}{l}\text { L.S. Krogsrud } \\
\text { P.R. Hernandez }\end{array}$ & Operational procedures are needed. & R.Y. Seda \\
\hline 2 & $\begin{array}{l}\text { J.K. Bajwa } \\
\text { J.E. Kane }\end{array}$ & $\begin{array}{l}\text { Shielding of the hands during installation needs } \\
\text { to be investigated. }\end{array}$ & R.Y. Seda \\
\hline 3 & C.G. Linschooten & $\begin{array}{l}\text { Use of anti spark materials needs to be } \\
\text { investigated. }\end{array}$ & R.Y. Seda \\
\hline 4 & R.L. Hand & Operational contract issues need to be resolved. & G.A. Barnes \\
\hline
\end{tabular}

\subsection{DOCUMENTATION}

The following items are provided as attachments to this report:

1. RCR copies

2. Meeting Minutes

Review copies of drawings provided to the review member are available in the vendor files. All released documentation referenced in the report will be available using vendor files or controlled document numbers located in the text where the document is cited. 
WHC-SD-WM-DRR-057

Rev 0

Page 10 of 10

\subsection{REFERENCE}

WHC-S-0241, Rev 2, "Specification for Enhanced Cone Penetrometer System"

WHC-SD-WM-SDD-062, Rev 0, "Cone Penetrometer Moisture Probe System Design Description"

WHC-SD-WM-SDD-063, Rev 0, "System Design Description Cone Penetrometer Systern"

WHC-SD-WM-ATR-145, Rev 0, "Cone Penetrometer Moisture Probe Acceptance Test Report"

WHC-SD-WM-FDC-047, Rev 1, "Functional Design Criteria Cone Penetrometer Moisture Probe" 
WHC-SD-WM-DRR-057

Rev 0

Page A-i

Appendix A: 100\% Design Review 
Department-0perationTWRS Component

Area Shift Date of Meeting $6 / 5 / 96$
Number

Attending

19

\section{Distribution:}

Attenders:

$\begin{array}{lll}\text { David J. Foust } & \text { WHC } & \text { ES\&Q (Radiation Control) } \\ \text { Mat E. Nolen } & \text { WHC } & \text { ES\&Q (Industrial Safety) } \\ \text { L. (Steve) Krogsrud } & \text { WHC } & \text { ES\&Q } \\ \text { Mike L. McElroy } & \text { WHC } & \text { Quality Assurance } \\ \text { G. (Jerry) R. Bloom } & \text { WHC } & \text { Disposal Engineering } \\ \text { Ron L. Butler } & \text { WHC Contracts Administration } \\ \text { Lonnie D. Draper } & \text { WHC } \text { Operations } \\ \text { Rosa Y. Seda } & \text { WHC Char. Equipment Development } \\ \text { Geoff A. Barnes } & \text { WHC Char. Equipment Development } \\ \text { Carl E. Hanson } & \text { WHC Char. Equipment Development } \\ \text { G. (Nick) Boechler } & \text { WHC Char. Equipment Development } \\ \text { Fred M. Jones } & \text { WHC } & \text { TWRS Engineering (Electrical) } \\ \text { Jim H. Bussell } & \text { WHC } & \text { TWRS Engineering (NEC Compl.) } \\ \text { Chris G. Linschooten } & \text { WHC } & \text { Char. Equipment Design } \\ \text { Paul R. Deichelbohrer WHC } & \text { Char. Equipment Design } \\ \text { John M. Silko } & \text { DOE } & \\ \text { Kevin Kyle } & \text { LLNL } & \\ \text { Wes Bratton } & \text { ARA } & \\ \text { Fred Johansen } & \text { SAIC } & \end{array}$

Other: J.S. Schofield, WHC

J.S. Lee, WHC

T.R. Farris, WHC

Rick E. Raymond, WHC

Dennis W. Hamilton, WHC

These are the meeting minutes documenting the final design presentation and meeting. The purpose of the meeting was to present the final design of the cone penetrometer system for tank waste. A vendor drawing package was distributed to the attenders of this meeting for independent review. Review Comment Record (RCR) will be generated and resolved after the meeting. This final design covers the design up to date. Changes associated with completion of the safety assessment will be covered at a later date.

This design covers the design of the cone penetrometer (CP) platform, which includes the support trailer and skid. The skid and support trailer were built by Applied Research Associates (ARA). Two other packages have been added to ARA's system. These include the Raman spectroscopy package, developed by Lawrence Livermore National 
Laboratory and the moisture probe package, developed by SAIC. The Raman spectroscopy system uses its own computer and the moisture probe shares the same computer with the rest of the CP system.

The $C P$ instrument package includes the physical properties sensors, Raman spectroscopy sensor, moisture sensor probe and tank safety sensors. The physical properties package includes sensors which will measure physical parameters. The physical sensor package includes tip pressure, pore pressure and sleeve friction. Load cells at the tip ( $t$ ip pressure) measure resistance of the material ahead of the tip while side load cells (friction sleeve) measure the friction as the cone pushes into the waste. Hydrostatic pressure (pore pressure) is measured by a sensing device also located within the tip. Safety related sensor include an inclinometer, redundant bottom detection system and side and tip thermistors. The inclinometer measures inclination to avoid rod buckling. The bottom detector measures if the tip is in proximity to the metal tank bottom. Temperature gauges alarm and shut down at a predetermined temperature. The CP sensor package cables are disconnected after a run with a 30 pin LEMO connector. The moisture probe is then lowered into the push rod interior. The moisture probe measures moisture content and tank temperature through two B-10 lined sensors and a thermistor. This package has undergone final design and acceptance testing.

The CP tip instrument package has been design to NFPA Class 1 Division 1 requirements. The sensor package is intrinsically safe by use of barriers and special conduits. A sealing flange and potting material exists between the sensor package and the explosion proof rods. The rods will be tested to 500 lbs to qualify for an explosion proof housing, per calculations on maximum peak pressure. The moisture probe is contained in the CP explosion proof housing, so that the system can be used in a Class 1 Division 1 environment.

The Raman spectroscopy sensor will perform chemical speciation. The sensor is insensitive to water and operates in the near infrared area. The detection level is $0.1 \%$ in solids and 1 iquids. It consists of a laser, monochromator, fiber optics, optics and housing with a metal brazed sapphire window. The window was chosen for its strength and chemical resistance and protrudes outward between 0 to $5 / 1000$ inches to prevent material from clogging on the window. A 2 inch adaptor connects the Raman housing to the 1.75 inch OD rod. The sensor is potted on the top. Seals used were viton o-rings. The laser and computer are rack mounted. The 250 feet radiation hardened fiber optics will be removed at the end of a run. The fiber optic cables are fairly flexible. The optics have a 4 inch bend radius while the other sensor cables have a 6 inch bend radius. The Raman spectroscopy sensor has been pressure tested and load tested. A neural network will be incorporated with the computer software at a later date. The fiber optic cable are aligned with a SMA connector (7) to the monochromator for slit alignment. The laser works with a $758 \mathrm{~nm}$ laser at $300 \mathrm{mV}$ laser output. There was some concern regarding the inner section of the raman spectroscopy housing which was made of aluminum. This section is located in the interior of the body and is not in contact with the waste.

The CP is powered by the support trailer. The trailer contains the generator, hydraulic pump, decontamination system and hydraulic reservoir. A diesel engine (John Deere) drives the hydraulic pump ( 300 psi, $30 \mathrm{mpm})$ and generator ( $800 \mathrm{kWatt})$. The hydraulic reservoir contains up to 700 galions. The hydraulics and decontamination hoses are unique as well as the 2 electrical cables. These are 50 feet long. 
The engine can run approximately 3 days due to the 36 gallon tank capacity. The support trailer contains a wood decking which needs to be changed, for decontamination purposes. Other concerns were regarding the cables and hoses not being marked. These hoses and cables are design such that they are not interchangeable.

The skid weight 20 tons and can be fully ballasted to 43 tons and jacked up $4 \mathrm{l} / 2$ feet high minimum to accommodate the riser adaptor and decontamination units. The skid is divided into two sections. The computer is contained in an environmentally controlled room with the Raman spectroscopy computer, laser, moisture probe calibration block and a workbench. The hydraulics are contained in the open section of the skid. A communication system exists between these two sections as well as a clear plexiglass door. Several safety features exist on the skid. These include skid tilt, emergency stop (palm button) and leveling bubble. The legs have been seismically analyzed. These are acceptable up to a 42 inch leg extension. A trolley system exists for the $31 / 2$ inch and 6 inch guide tubes. The overhead winch has 500 lbs 1 ifting capability. The $x-y$ positioned has a total travel of 12 inches and clamps mechanically in the $x$ direction and hydraulically in the $y$ direction.

The computer system consists of monitor, computer, junction box, VXI D/A system, NIM BIN, UPS, printer, line conditioners and modem. These are contained in a 6 feet full height rack. The junction box contains the intrinsically safe barriers. The $D / A$ system contains 22 analog channels and 32 digital channels. A battery backup exists inside the control room. There is some concern on the possible effects of the battery backup on the operator. The number of ventilation room changes will be examined to determine if the battery design needs to be changed.

Several safety features exist for tank integrity. These include mechanical means as well as alarms. Safety legs, mechanical clamps and double hydraulic clamps exist to avoid dropping the skid on the tank and dropping the guide tube and push rod into the waste. A dome load alarm exist in which the user inputs the skid configuration (ballast, $1 / 2$ ballast and no ballast) and monitors the ram force as not to exceed the limit. Other tank safety systems include the redundant bottom detector, high tip force, depth alarms and high temperature alarm.

The basic operation of the cone penetrometer system as follow:

\section{RISER PREPARATION}

This activity will be performed prior to the installation of the cone penetrometer to verify riser availability and ensure that there are no obstructions. The inspection will provide the following information:

* Zip cord measurements to provide distance from top of the riser to waste surface and riser length measurements.

* Video camera footage to provide a view of the inside of the tank and in particular, the waste surface below the riser.

* For 4 inch risers, the riser will be measured for diameter, ovality and straightness of the riser. 
*

Install riser adapter and decontamination unit

* Place skid over riser using crane (legs fully extended)

* Ground all equipment

* Position support trailer (off the tank, when possible) and connect to skid. This includes decontamination water, hydraulic lines and electrical power.

* Level skid

* Position $X-Y$ to within \pm 0.25 inches of riser center

* Ballast as required

* Re-level, if needed

INSTALLATION OF GUIDE TUBES AND PUSH RODS

* Assemble Guide tube to length required to reach top of waste

* Lower Guide tube in place with crane. Secure guide tube with clamps.

* Lower push rod in one meter sections.

PHYSICAL PROPERTIES AND RAMAN TEST RUN

* Push cone penetrometer push rod into waste

* Data acquisition system collects data (Raman and physical properties) during push

* Data acquisition system monitors all safety conditions

* Reach end condition (tank bottom)

* Disconnect electrical and fiber optic cable from probe

MOISTURE PROBE TEST RUN

* Load moisture sensor source in probe housing

* Calibrate moisture probe in calibration block

* Position moisture sensor over push rod

* Lower moisture sensor in push rod and take moisture/temperature readings.

* Retract moisture sensor. Remove source and store moisture probe.

\section{EQUIPMENT REMOVAL}

* Start decontamination system

* Attach coupler - allow crane to lift both rod and guide tube at the same time. Decontaminate equipment.

* Cover with plastic containment sleeve and monitor radiation levels using standard tank farm techniques while removing from the riser. Guide tube an push rods will be broken down such that the push rod or guide tubes in contact with the waste are disposed.

* Seal riser.

* Remove trailer and skid, in reverse of installation.

\section{TEST COMPLETION:}

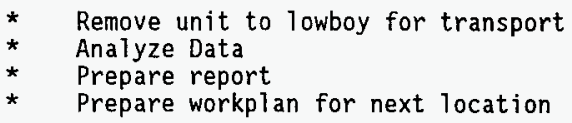

The deployment of the cone penetrometer in the field date is undetermined due to funding constraints. Attached are the slides used 
during the presentation. Drawings submitted during the final design WHC-SD-WM-DRR-057 review will be independently reviewed.

REV 0

Page A-5

A-3000-480 (10/94) GEF011 


\section{REVIEW COMMENT RECORD (RCR)}

$\begin{aligned} & \text { 1. Date } \\ & \text { June } 8,1996\end{aligned}$
3. Project No.

2. Review No.

3. Project No.

1 of 1

5. Document Number(s)/Title(s)

Cone Penetrometer Final Design Review

17. Comment Submittal Approval:

Organization Manager (Optional)

$\frac{6 / 5 / 96}{\text { Date }}$

6. Program/Project/

Clding Number

Cone

Penetrometer

10. Agreement with indicated comment disposition(s)

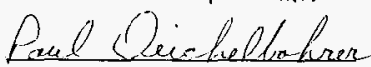
Reviewer/Point of contact

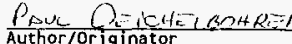

\section{Organization/Group \\ CHARACTEETZATIUN \\ EQU.PMENT}

11. CLOSED

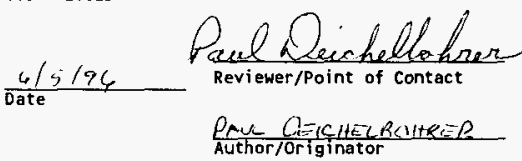

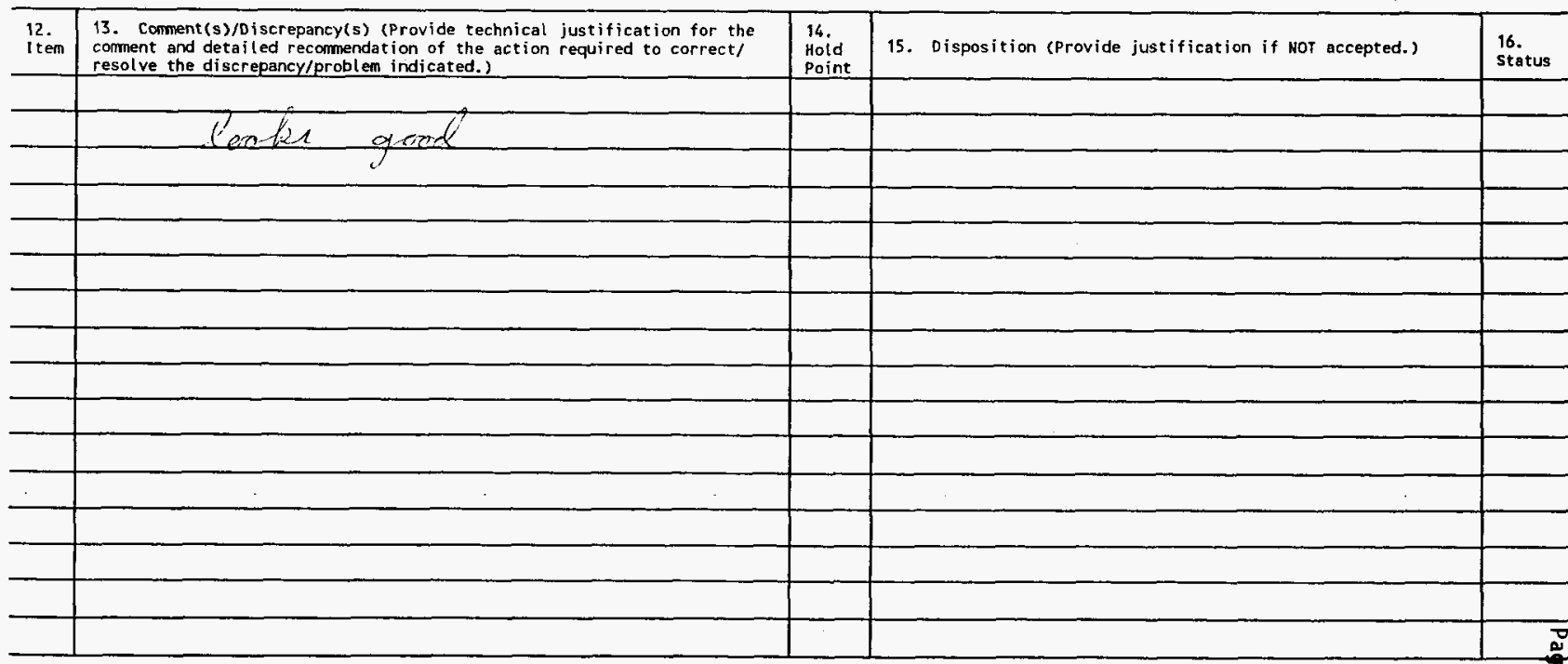

A-6400-090.1 (03/92) WEF011
9. Location/Phone

$3>3-2037$

$57-12$ 


\section{REVIEW COMMENT RECORD (RCR)}

\begin{tabular}{|l|l|}
\hline $\begin{array}{l}\text { 1. Date } \\
\text { June 8, 1996 }\end{array}$ & 2. Review No. \\
\hline 3. Project No. & 4. Page 1 of 1 \\
\hline
\end{tabular}

5. Document Number(s)/Title(s)

Cone Penetrometer Final Design Review

17. Comment Submittal Approval:

Organization Manager (Optional)
6. Program/Project/ Building Number

Cone

Penetrometer

10. Agreement with indicated coment disposition(s) Q.lW deck for S.krogsruel

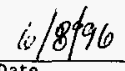
Reviewer/Pbint of Contact RY Sede
8. Organization/Group
9. Location/Phone

M0281/2-2302 per telee on

\section{\begin{tabular}{l|l}
\hline Steve Krogsrud & TWRS/TFP
\end{tabular}}

11. CLOSED

$6 / 19 / 96$

Date ey seda for 5 . Krogsrud per tolecen. Reviewer/Point of Contact

Author/Originator

\begin{tabular}{|c|c|c|c|c|}
\hline $\begin{array}{l}12 . \\
\text { I tem }\end{array}$ & $\begin{array}{l}\text { 13. Comment(s)/Discrepancy(s) (Provide technical justification for the } \\
\text { comment and detailed recommendation of the action required to correct/ } \\
\text { resolve the discrepancy/problem indicated.) }\end{array}$ & $\begin{array}{l}14 . \\
\text { Hoid } \\
\text { Point }\end{array}$ & 15. Disposition (Provide justification if NOT accepted.) & $\begin{array}{l}16 . \\
\text { Status }\end{array}$ \\
\hline & No comment & & & \\
\hline & & & & \\
\hline & & & & \\
\hline & & & - & \\
\hline & & & & \\
\hline & & & & \\
\hline & & & & \\
\hline & . & & & \\
\hline & & & & \\
\hline & & & & \\
\hline & & & & \\
\hline & & & & \\
\hline & & & & \\
\hline & & & & \\
\hline & & & & \\
\hline
\end{tabular}




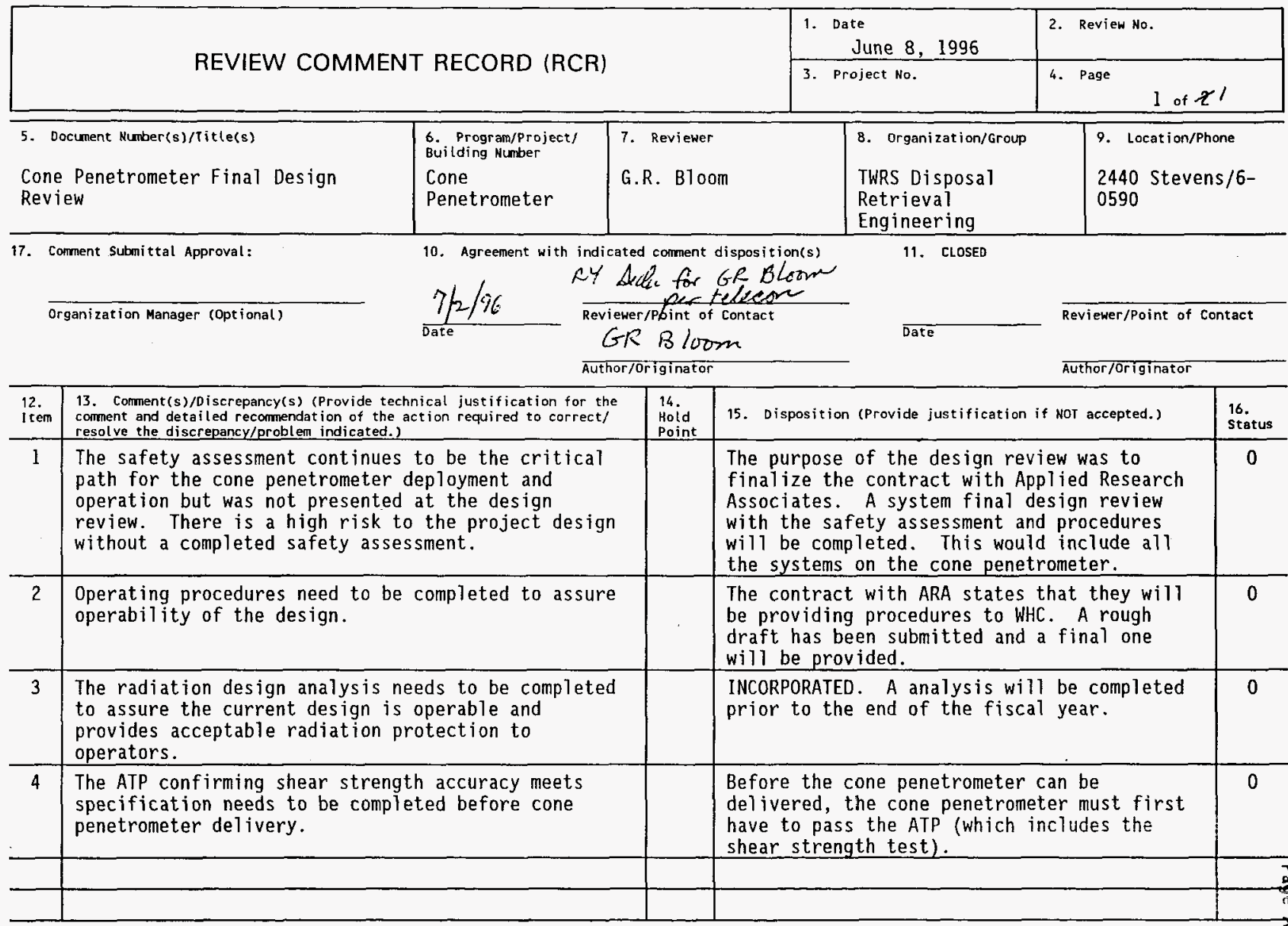

A-6400-090.1 (03/92) HEF011 


\begin{tabular}{|l|l|l|}
\hline \multirow{2}{*}{ REVIEW COMMENT RECORD (RCR) } & 1. Date & $6 / 14 / 96$ \\
\cline { 2 - 3 } & 3. Project No. Review No. & 4. Page \\
\hline
\end{tabular}

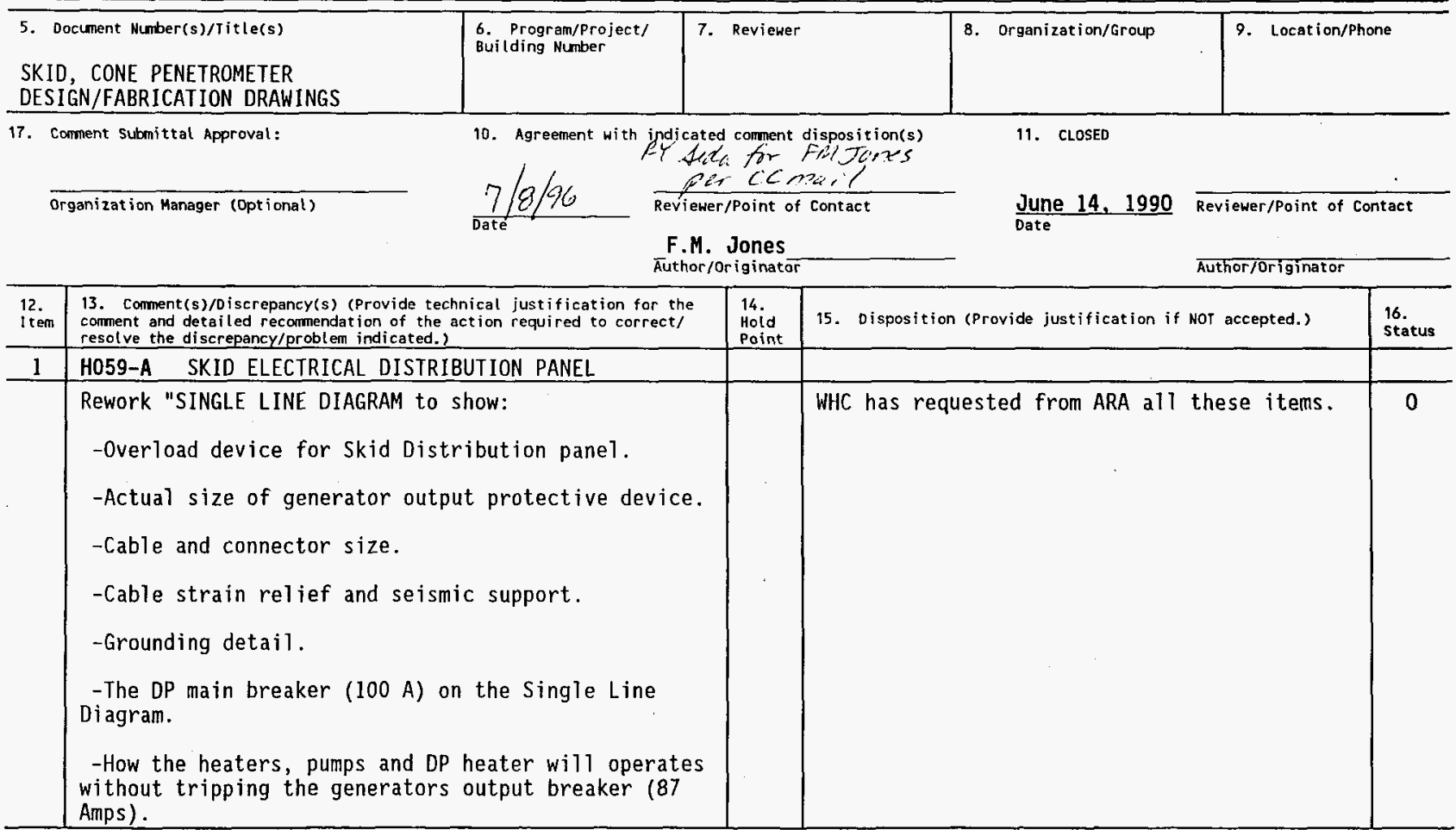

without tripping the generators output breaker ( 87 Amps). 


\begin{tabular}{|l|l|l|l|}
\hline \multirow{2}{*}{ REVIEW COMMENT RECORD (RCR) } & $\begin{array}{l}\text { 1. Date } \\
6 / 14 / 96\end{array}$ & Review No. \\
\cline { 2 - 4 } & 3. Project No. & 4. Page \\
\hline
\end{tabular}

\begin{tabular}{|c|c|c|c|c|}
\hline $\begin{array}{l}12 . \\
\text { Item }\end{array}$ & $\begin{array}{l}\text { 13. Comment(s)/Discrepancy(s) (Provide technical justification for the } \\
\text { conment and detailed recomendation of the action required to correct/ } \\
\text { resolve the discrepancy/problem indicated.) }\end{array}$ & $\begin{array}{l}14 . \\
\text { Hold } \\
\text { Point }\end{array}$ & 15. Disposition (Provide justification if NOT accepted.) & $\begin{array}{l}16 . \\
\text { status }\end{array}$ \\
\hline \multirow[t]{2}{*}{2} & H059-3A ELECTRICAL DISTRIBUTION PANEL & & & \\
\hline & $\begin{array}{l}\text {-Identify the fuses in the circuit controlled by } K- \\
18 . \\
\text {-Size the fuses in the circuit controlled by } K-18 \text {. }\end{array}$ & & $\begin{array}{l}\text { WHC has requested from ARA a } 11 \text { these items } \\
\text { and changes. }\end{array}$ & 0 \\
\hline \multirow[t]{2}{*}{3} & $\mathrm{H} 130-3 \mathrm{~A}$ & & & \\
\hline & $\begin{array}{l}\text {-The term } 120 \mathrm{~V} \text { AC "DIRTY" is not acceptable. } \\
\text {-If this is unfiltered or unregulated, say so. } \\
\text {-Show the } 24 \mathrm{~V} \text { and } 12 \mathrm{~V} \text { power supplies on one of } \\
\text { the drawings. }\end{array}$ & & $\begin{array}{l}\text { WHC has requested from ARA a11 these items } \\
\text { and changes. }\end{array}$ & 0 \\
\hline & & & & \\
\hline 4 & GENERAL & & & \\
\hline
\end{tabular}




\begin{tabular}{|l|l|l|}
\hline \multirow{2}{*}{ REVIEW COMMENT RECORD (RCR) } & 1. Date $6 / 14 / 96$ & Review No. \\
\cline { 2 - 4 } & 3. Praject No. & 4. Page \\
\hline
\end{tabular}

\begin{tabular}{|c|c|c|c|c|}
\hline $\begin{array}{l}12 . \\
\text { Item }\end{array}$ & $\begin{array}{l}\text { 13. Comment(s)/Discrepancy(s) (Provide technical justification for the } \\
\text { comment and detailed recomnendation of the action required to correct/ } \\
\text { resolve the discrepancy/problem indicated.) }\end{array}$ & $\begin{array}{l}14 . \\
\text { Hoid } \\
\text { Point }\end{array}$ & 15. Disposition (Provide justification if NOT arcepted.) & $\begin{array}{l}16 . \\
\text { Status }\end{array}$ \\
\hline & $\begin{array}{l}\text { - The drawings are not approved. } \\
\text { - Show seismic analysis that includes overhead } \\
\text { structures on the skid. } \\
\text {-Batteries (lead acid) shall be vented to outside } \\
\text { area. } \\
\text {-(ALARA) Isolation valve should be used on the } \\
\text { riser for personnel protection (Radiation shine) } \\
\text { during setup. }\end{array}$ & $\begin{array}{l}\text { HOLD } \\
\text { HOLD } \\
\text {. }\end{array}$ & $\begin{array}{l}\text {-WHC has requested from ARA to fix the } \\
\text { drawings. } \\
\text { - The seismic analysis is contained in ETS-W- } \\
96-849 \text {, "Cone Penetrometer Skid Seismic } \\
\text { Analysis". The model used for the cone } \\
\text { penetrometer is described in section } 2.1 \\
\text { Model Description. It was completed by F.G. } \\
\text { Abatt, March 19, 1996. } \\
\text {-The ventilation for the lead acid batteries } \\
\text { is adequate. The air conditioning units } \\
\text { change air } 25 \text { times per hour each (total of } \\
\text { two units). oSHA requires } 5 \text { room changes } \\
\text { per hour. The ventilation is adequate for } \\
\text { OSHA venting requirements. } \\
\text { - This response has not considered } \\
\text { ALARA. The isolation valve would be used to } \\
\text { close-off the tank following removal and } \\
\text { reinstallation of the flange. A } 4 \text { inch hole } \\
\text { (flange opening) in a tank is unacceptable. } \\
\text {-Before any isolation valves are used, an } \\
\text { analysis estimating the dose will be } \\
\text { completed. At all times (except when } \\
\text { craning in the guide tube or push rod or } \\
\text { combination), two clamps will be oN at all } \\
\text { times on the guide tube and push rod. This } \\
\text { basically provides the same protection as an } \\
\text { isolation valve. When the guide tube or } \\
\text { push rod is being crane in, there should be } \\
\text { no manual operations around the riser. } \\
\text { > - okay, close this item. }\end{array}$ & 总点 \\
\hline
\end{tabular}


WHC-SD-WM-DRR-057 REV 10

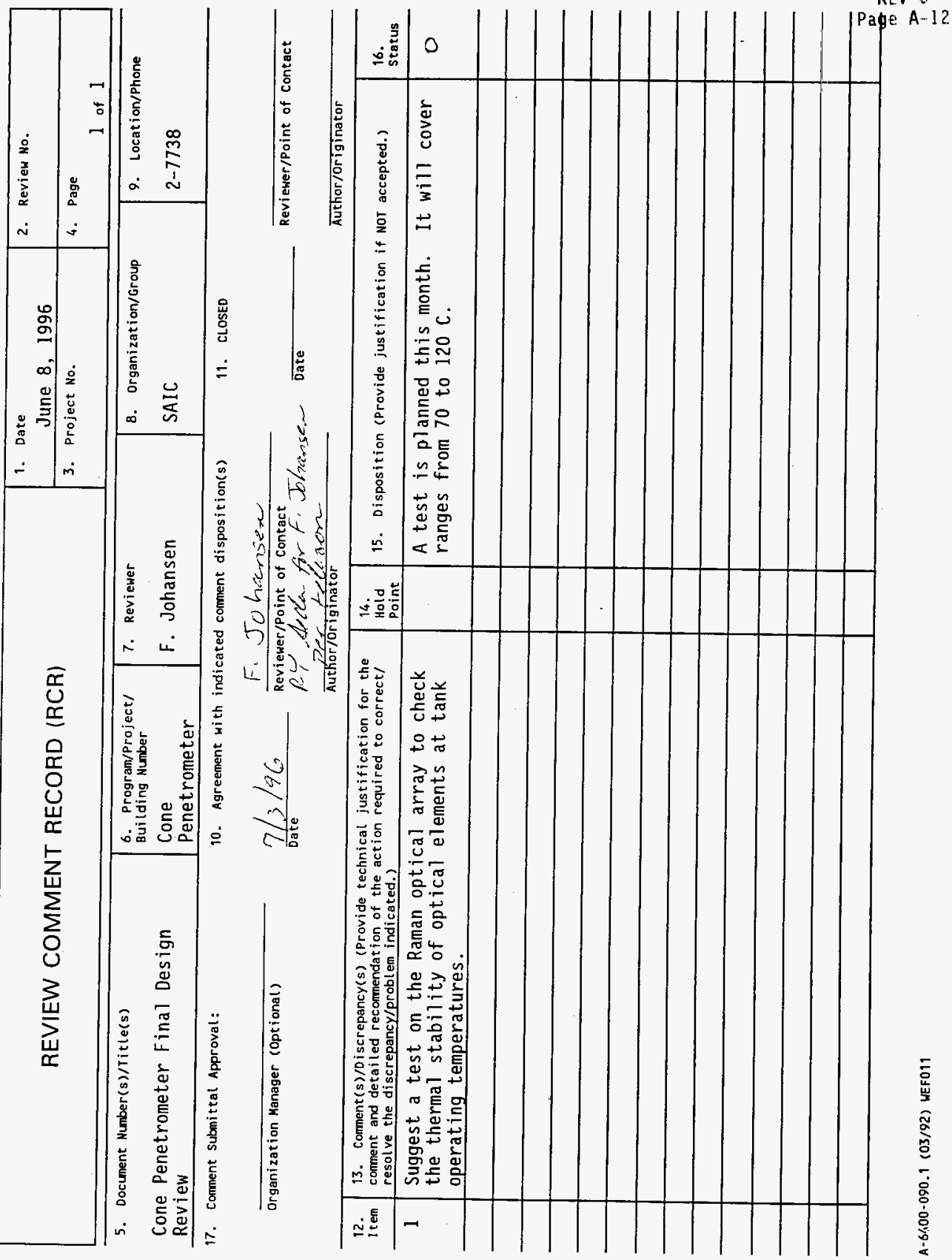




\section{REVIEW COMMENT RECORD (RCR)}

\begin{tabular}{|l|l|}
\hline $\begin{array}{c}\text { 1. Date } \\
\text { June } 8,1996\end{array}$ & 2. Review No. \\
\hline 3. Project No. & 4. Page of 1 \\
\hline
\end{tabular}

\begin{tabular}{|c|c|c|c|c|}
\hline 5. Document Number(s)/Title(s) & $\begin{array}{l}\text { 6. Program/Project/ } \\
\text { Building Number }\end{array}$ & 7. Reviewer & 8. Organization/Group & 9. Location/Phone \\
\hline $\begin{array}{l}\text { Cone Penetrometer Final Design } \\
\text { Review }\end{array}$ & $\begin{array}{l}\text { Cone } \\
\text { Penetrometer }\end{array}$ & John M. Silko & DOE-RL/CHD/WSD & $2704 \mathrm{HV} / 3-9876$ \\
\hline
\end{tabular}

17. Comment Submittal Approval:

Organization Manager (Optional)
10. Agreement with indicated coment disposition(s)

$$
\text { CY Sedit for JA Silko }
$$$$
7 / 2196 \text { pis telecter }
$$$$
\frac{1 / 2 / 96}{\text { Date }} \text { Reviewer/Point of Contact }
$$

Th siko

Author/originator
11. CLOSED

\section{Reviewer/Point of Contact}

Date

Author/Originat or

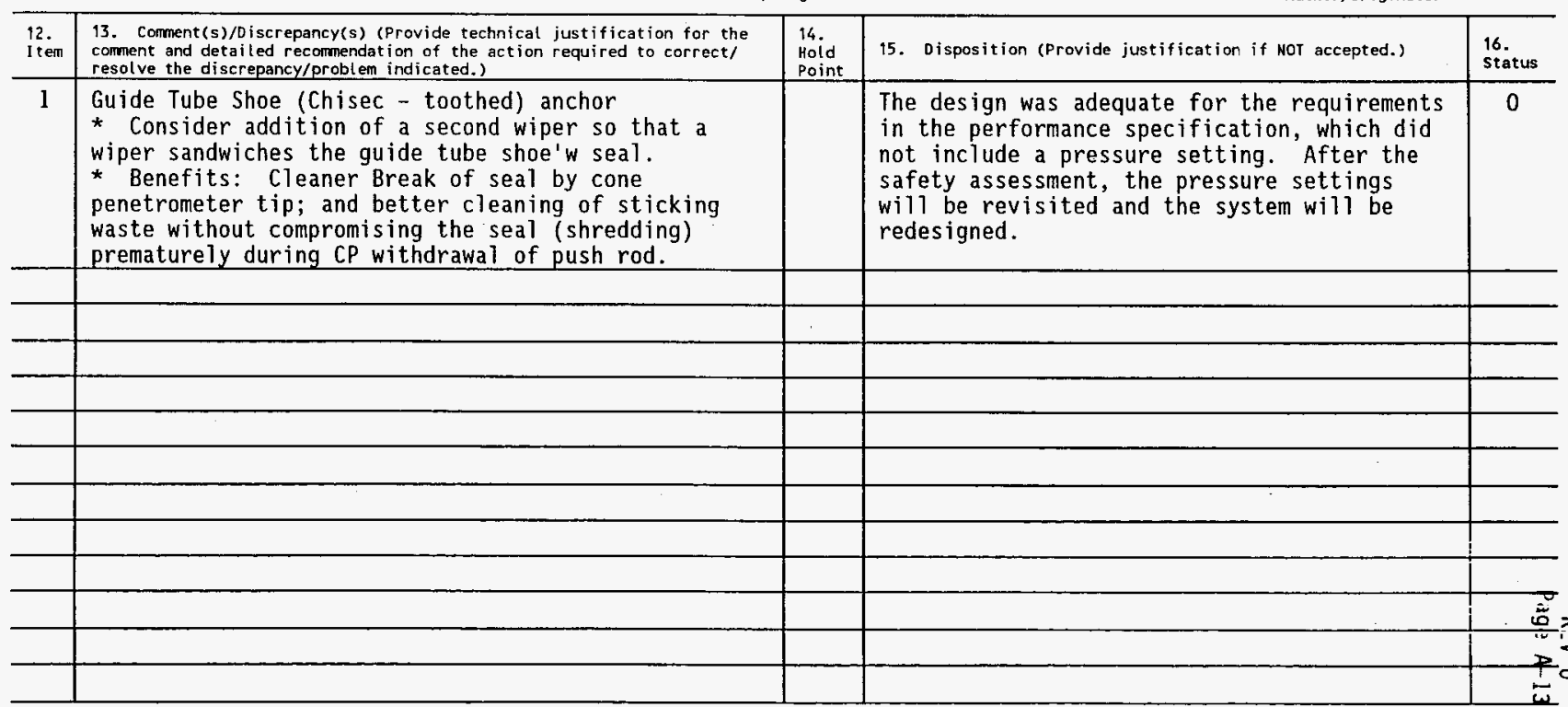




\begin{tabular}{|l|l|l|}
\hline \multirow{2}{*}{ REVIEW COMMENT RECORD (RCR) } & $\begin{array}{l}\text { 1. Date } \\
12 \text { Jun 96 }\end{array}$ & 2. Review No. \\
\cline { 2 - 4 } & $\begin{array}{l}\text { 3. Project No. } \\
\text { Cone Penetrometer }\end{array}$ & $\begin{array}{l}4 . \text { Page } \\
1 \text { of } 1\end{array}$ \\
\hline & & \\
\hline
\end{tabular}

\begin{tabular}{l|l|l|l|l}
\hline 5. Document Number(s)/Title(s) & $\begin{array}{l}\text { 6. Program/Project/ } \\
\text { Building Number } \\
\text { Cone } \\
\text { Penetrometer }\end{array}$ & 7. Reviewer & Matthew E. Nolen & WTF IS \\
$\begin{array}{l}\text { Cone Penetrometer Final Design } \\
\text { Review }\end{array}$ & & & & $\begin{array}{l}\text { M0-281/106/2- } \\
2918\end{array}$ \\
\hline
\end{tabular}

17. Comment Submittal Approval:

Organization Manager (Optional)
10. Agreement with indicated comment disposition(s)

$7 / 16 / 96$ Date Ei suela fir Me Nolen

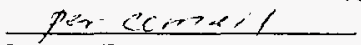
Reviewer/Point of Contact

11. CLOSED

Author/Originator

Reviewer/Point of Contact

Date

Author/Originator 


\begin{tabular}{|l|l|l|}
\hline \multirow{2}{*}{ REVIEW COMMENT RECORD (RCR) } & $\begin{array}{l}\text { 1. Date } \\
\text { 12. Jun 96 }\end{array}$ & 2. Review No. \\
\cline { 2 - 4 } & $\begin{array}{l}\text { 3. Project No. } \\
\text { Cone Penetrometer }\end{array}$ & \begin{tabular}{l} 
4. Page 2 of 1 \\
\hline
\end{tabular} \\
\hline & & \\
\hline
\end{tabular}

\begin{tabular}{|c|c|c|c|c|}
\hline $\begin{array}{l}12 . \\
\text { Ite } \\
\text { m }\end{array}$ & $\begin{array}{l}\text { 13. Comment(s)/Discrepancy(s) (Provide technical justification } \\
\text { for the comment and detailed recommendation of the action required } \\
\text { to correct/ resolve the discrepancy/problem indicated.) }\end{array}$ & $\begin{array}{l}14 . \\
\text { Hold } \\
\text { Point }\end{array}$ & $\begin{array}{l}\text { 15. Disposition (Provide justification if NOT } \\
\text { accepted.) }\end{array}$ & $\begin{array}{l}16 . \\
\text { Statu } \\
\text { s. }\end{array}$ \\
\hline 1 & $\begin{array}{l}\text { Is the potting compound approved for use in an } \\
\text { explosive environment? IE UL approved? }\end{array}$ & Men & $\begin{array}{l}\text { The purpose of the encapsulation is to } \\
\text { provide an additional barrier between } \\
\text { flammable vapors and possible ignition } \\
\text { sources. The sensors package has been made } \\
\text { intrinsically safe. Encapsulation (potting) } \\
\text { is an accepted ignition prevention method } \\
\text { for Class I. Div } 1 \text { Group B locations. This } \\
\text { potting material is meets the requirements } \\
\text { for an explosive environment but is not UL } \\
\text { listed. None of the UL listed potting } \\
\text { materials were appropriate for the tank } \\
\text { environment (temperature). }\end{array}$ & $\mathrm{C}$ \\
\hline 2 & $\begin{array}{l}\text { WHC-SD-WM-SDD-063 Page } 27 \text { : Is it ground only or bond } \\
\text { and ground? Ref the current tank farm procedures. }\end{array}$ & Men & $\begin{array}{l}\text { The current method is ground and bond. This } \\
\text { is what the specification requires. }\end{array}$ & C \\
\hline 3 & What are the feet sizes? (Elephant and normal) & men & $\begin{array}{l}\text { The elephant feet are } 18 \text { inch diameter } \\
\text { (H088-6A) and the pads are } 12 \text { inches in } \\
\text { diameter (H065-2A). The pads will be on the } \\
\text { elephant feet all the time, so your } \\
\text { "footprint" is } 18 \text { inches in diameter. }\end{array}$ & C \\
\hline 4 & Are there any locking stops for the HVAC unit? & Men & $\begin{array}{l}\text { No. The unit is fixed on the top of the } \\
\text { skid (it does not roll around). }\end{array}$ & C \\
\hline
\end{tabular}




\begin{tabular}{|l|l|l|l|}
\hline \multirow{2}{*}{ REVIEW COMMENT RECORD (RCR) } & $\begin{array}{l}\text { 1. Date } \\
12 \text { Jun 96 }\end{array}$ & Review No. \\
\cline { 2 - 4 } & $\begin{array}{c}\text { 3. Project No. } \\
\text { Cone Penetrometer }\end{array}$ & $\begin{array}{l}\text { 4. Page } \\
3 \text { of } 1\end{array}$ \\
\hline & & & \\
\hline
\end{tabular}

\begin{tabular}{|c|c|c|c|c|}
\hline $\begin{array}{l}12 . \\
\text { Ite } \\
\text { m } \\
\end{array}$ & $\begin{array}{l}\text { 13. Corment(s)/Discrepancy(s) (Provide technical justification } \\
\text { for the comment and detailed recommendation of the action required } \\
\text { to correct/ resolve the discrepancy/problem indicated.) }\end{array}$ & $\begin{array}{l}14 \\
\text { Hoid } \\
\text { Point } \\
\end{array}$ & $\begin{array}{l}\text { 15. Disposition (Provide justification if NOT } \\
\text { accepted.) }\end{array}$ & $\begin{array}{l}16 . \\
\text { Statu } \\
5\end{array}$ \\
\hline 5 & What is the air flow? (ACH or CFM) & men & $\begin{array}{l}340 \text { CFM for a } 400 \mathrm{cu} \text { feet room. The ATP } \\
\text { showed that the number of room changes per } \\
\text { hour was } 25 \text { for each air conditioning unit } \\
\text { (total 2). }\end{array}$ & $\mathrm{C}$ \\
\hline 6 & Why a lead acid battery? NICAD? & Men & $\begin{array}{l}\text { Economy. The room changes is adequate for } \\
\text { this battery type. } 50 \text { plus } \mathrm{ACH} \text {. }\end{array}$ & $\mathrm{C}$ \\
\hline 7 & Are there any exposed pinch points on the $A C$ rails? & Men & None found in the ATP. & $\mathrm{C}$ \\
\hline 8 & 3000psi - secure lines to prevent flailing & men & INCORPORATED. & 0 \\
\hline 9 & Label all connectors & men & INCORPORATED. & 0 \\
\hline 10 & $\begin{array}{l}\text { Wood deck on support trailer needs to be made of } \\
\text { metal as well as the stake bed rails. No wood in } \\
\text { farms. }\end{array}$ & Men & $\begin{array}{l}\text { Incorporated. The wood will be replaced } \\
\text { with metal. }\end{array}$ & 0 \\
\hline 11 & $\begin{array}{l}\text { Need all of the specifications on the winch and the } \\
\text { trolley system to ensure it will hold what it is } \\
\text { designed for. }\end{array}$ & Men & $\begin{array}{l}\text { The winch is rated to } 5,000 \text { lbs. Vendor } \\
\text { information is being obtained on the winch } \\
\text { and trolley system. }\end{array}$ & 0 \\
\hline 12 & Labei trolley for load allowed. & Men & $\begin{array}{l}\text { The winch is currently labeled. Inspection } \\
\text { will verify this. }\end{array}$ & 0 \\
\hline 13 & load test winch & men & $\begin{array}{l}\text { The winch is rated to } 5.000 \text { lbs and will be } \\
\text { tested in the OTP. }\end{array}$ & 0 \\
\hline
\end{tabular}




\begin{tabular}{|l|l|l|l|}
\hline \multirow{2}{*}{ REVIEW COMMENT RECORD (RCR) } & $\begin{array}{l}\text { 1. Date } \\
12 \text { Jun } 96\end{array}$ & Review No. \\
\cline { 2 - 4 } & $\begin{array}{c}\text { 3. Project No. } \\
\text { Cone Penetrometer }\end{array}$ & $\begin{array}{c}\text { 4. Page } \\
4 \text { of } 1\end{array}$ \\
\hline & & & \\
\hline
\end{tabular}

\begin{tabular}{|c|c|c|c|c|}
\hline $\begin{array}{l}12 . \\
\text { Ite } \\
\text { m }\end{array}$ & $\begin{array}{l}\text { 13. Comment(s)/Discrepancy(s) (Provide technical justification } \\
\text { for the comment and detailed recommendation of the act ion required } \\
\text { to correct/ resolve the discrepancy/problem indicated.) }\end{array}$ & $\begin{array}{l}14 \\
\text { Hold } \\
\text { Point }\end{array}$ & $\begin{array}{l}\text { 15. Disposition (Provide justification if NOT } \\
\text { accepted.) }\end{array}$ & $\begin{array}{l}16 . \\
\text { Statu } \\
\text { s }\end{array}$ \\
\hline 14 & $\begin{array}{l}\text { Where and how will atmospheric checks be made during } \\
\text { operation of the unit. }\end{array}$ & Men & $\begin{array}{l}\text { The core sample truck has atmospheric checks } \\
\text { made around the drill string. An industrial } \\
\text { hygienist needs to examine the operation to } \\
\text { determine frequency and location. }\end{array}$ & 0 \\
\hline 15 & $\begin{array}{l}\text { Ergonomic concerns for monitors. Need height and } \\
\text { placement of monitors. }\end{array}$ & Men & $\begin{array}{l}\text { The height and location were not on the } \\
\text { drawings. WHC has requested from ARA to } \\
\text { include these in the drawings. }\end{array}$ & 0 \\
\hline 16 & Are there any seats to be used? & Men & No. contingent to funding. To be resolved. & 0 \\
\hline 17 & $\begin{array}{l}\text { Add a wafer to the unit. (An additional thick } \\
\text { washer to scrape the barrel of the probe. Thick - } \\
\text { thin - thick. }\end{array}$ & Men & $\begin{array}{l}\text { The design was adequate for the requirements } \\
\text { in the performance specification, which did } \\
\text { not include a pressure setting. After the } \\
\text { safety assessment, the pressure settings } \\
\text { will be revisited and the system will be } \\
\text { redesigned. }\end{array}$ & 0 \\
\hline
\end{tabular}


DON'T SAY IT -.. write It! DATE: 16 July 96

WHC-SD-WM-DRR-057

REV 0

Page A-18

TO: Rosa Y Seda

FROM: Matthew E. Nolen

$$
\begin{aligned}
& \text { Telephone: } 372-2918 \\
& \text { cc:Hulsey. S }
\end{aligned}
$$

SUBJECT: Cone Penetrometer RCR

The open items are to remain open until the final construction and OTP of the piece of equipment. The specifications are enrout from Rosa $Y$ Seda as of 16 July 96. The ergonomic concerns will be reviewed along with the atmospheric check requirements by Roger Mitchel1. CIH before and during the OTP. The final design is needed to determine just what must be done to protect the workers.

Matthew $E$. Nolen

Industrial Safety Engineer

WTFTP. EH\&S 


\begin{tabular}{|l|l|l|}
\hline \multirow{2}{*}{ REVIEW COMMENT RECORD (RCR) } & $\begin{array}{c}\text { 1. Date } \\
\text { June } 8,1996\end{array}$ & Review No. \\
\cline { 2 - 3 } & 3. Project No. & 4. Page \\
\end{tabular}

\begin{tabular}{l|l|l|l}
\hline $\begin{array}{l}\text { 5. Document Number(s)/Title(s) } \\
\text { Cone Penetrometer Final Design } \\
\text { Review }\end{array}$ & $\begin{array}{l}\text { 6. Program/Project/ } \\
\text { Building Number } \\
\text { Cone } \\
\text { Penetrometer }\end{array}$ & $\begin{array}{l}\text { 7. Reviewer } \\
\text { C.G. Linschooten }\end{array}$ & CED \\
\hline 17. Conment Submittal Approval: & 10. Agreement with indicateg gorment disposition(s) \\
\hline Organization Manager (Optional) &
\end{tabular}

Author/Originator

Date

9. Location/Phone

2704HV/3-1617

11. CLOSED

\begin{tabular}{|c|c|c|c|c|}
\hline $\begin{array}{l}92 . \\
\text { iten }\end{array}$ & $\begin{array}{l}\text { 13. Comment (s)/Discrepancy(s) (Provide technical justification for the } \\
\text { comment and detail ed recommendat ion of the action required to correct/ } \\
\text { resolve the discrepancy/problem indicated.) }\end{array}$ & $\begin{array}{l}14 . \\
\text { Hold } \\
\text { Point }\end{array}$ & 15. Disposition (Provide justification if NOT accepted.) & $\begin{array}{l}16 . \\
\text { status }\end{array}$ \\
\hline 1 & $\begin{array}{l}\text { The ballast loads do not indicate what the total } \\
\text { weight is and what is it filled with. Like lead, } \\
\text { water or sawdust. }\end{array}$ & & $\begin{array}{l}\text { The ballast weights are fully encased lead } \\
\text { filled A36 steel boxes. The ballast are set } \\
\text { as } 2 \text { front ballast ( } 15,0001 \mathrm{~b} \text { each) and four } \\
\text { back ballast }(6,000 \text { lb each). This } \\
\text { information is required for } 1 \text { ifting the } \\
\text { ballast to install on the CP. WHC will ask } \\
\text { ARA to incorporate this information on the } \\
\text { drawings. }\end{array}$ & 0 \\
\hline 2 & $\begin{array}{l}\text { All items that have to be carried or picked should } \\
\text { have a weight indicated on the drawing and the part. }\end{array}$ & & $\begin{array}{l}\text { This comment is in the same order as comment } \\
\text { l. WHC will ask ARA to incorporate this } \\
\text { change. }\end{array}$ & 0 \\
\hline 3 & $\begin{array}{l}\text { Are lifting loads tested like } 11 / 2 \text { times nominal } \\
\text { loads and recorded? }\end{array}$ & & $\begin{array}{l}\text { WHC-SD-WM-ATP-151 will be testing lifting } \\
\text { device as follow: Critical welds shall be } \\
\text { examined prior to and after loading the cone } \\
\text { penetrometer to } 1.5 \text { times the maximum } \\
\text { operating load. Critical welds shall be } \\
\text { identified by WHC prior to fabrication. } \\
\text { Examination shall consist of VT and MT or PT } \\
\text { per AWS D1.1 on the final weld pass. }\end{array}$ & C \\
\hline 4 & $\begin{array}{l}\text { Do the drawings reflect the actual (as built) } \\
\text { conditions? }\end{array}$ & & $\begin{array}{l}\text { No. WHC has requested better drawings from } \\
\text { ARA. However, WHC level of effort drawings } \\
\text { were not requested. }\end{array}$ & $\underset{0}{0}$ \\
\hline
\end{tabular}




\begin{tabular}{|c|c|c|}
\hline & $\begin{array}{l}\text { 1. Date } \\
\text { June 8, } 1996\end{array}$ & 2. Review No. \\
\hline REVIEV LUMIVIEI RECURD (RCR) & 3. Project No. & 4. Page \\
\hline
\end{tabular}

\begin{tabular}{|c|c|c|c|c|}
\hline $\begin{array}{l}\text { 12. } \\
\text { Item }\end{array}$ & $\begin{array}{l}\text { 13. Comment(s)/Discrepancy(s) (Provide technical justification for the } \\
\text { comment and detailed recommendat ion of the action required to correct/ } \\
\text { resolve the discrepancy/problem indicated.) }\end{array}$ & $\begin{array}{l}14 . \\
\text { Hold } \\
\text { Point }\end{array}$ & 15. Disposition (Provide justification if NOT accepted.) & $\begin{array}{l}16 . \\
\text { Status }\end{array}$ \\
\hline 5 & $\begin{array}{l}\text { Are the electrical hook-ups compatible with the new } \\
\text { hook-up requirements in the Tank Farm (see Jim } \\
\text { Daniels/Bruce Johns)? }\end{array}$ & & $\begin{array}{l}\text { Jim Daniels and Fred Jones have reviewed the } \\
\text { documentation and cannot make any } \\
\text { conclusions. WHC has requested from ARA the } \\
\text { documentation required to evaluate this. }\end{array}$ & 0 \\
\hline 6 & Is ARA going to run the whole show or not? & & $\begin{array}{l}\text { Assuming that there was money in the budget } \\
\text { for operation of the CP, ARA would be } \\
\text { running the system with operations running } \\
\text { the setup and shutdown of the system. }\end{array}$ & 0 \\
\hline 7 & $\begin{array}{l}\text { Mechanical holding clamp on guide tube or } \\
\text { penetrometer will it catch a falling tube? }\end{array}$ & & Yes. Analysis has been conducted on it. & C \\
\hline 8 & $\begin{array}{l}\text { Is there a minimum waste tank level where we will be } \\
\text { operate or not operate. }\end{array}$ & & $\begin{array}{l}\text { Yes, these are the minimum waste depth on } \\
\text { the measurements desired: } \\
\text { Physical Properties } 8 \text { inches } \\
\text { Chemical Species } 24 \text { inches } \\
\text { Surface Moisture Measurements: } 32 \text { inches } \\
\text { Profile Moisture Measurements: } 60 \text { inches }\end{array}$ & C \\
\hline 9 & $\begin{array}{l}\text { Are the dual cylinder in the system tested and do } \\
\text { they operate } 0 . K \text {. like at maximum required speed. }\end{array}$ & & $\begin{array}{l}\text { Yes. The cylinders were tested during ATP. } \\
\text { They operate at } 2 \mathrm{~cm} / \mathrm{sec} \text { with a maximum } \\
\text { speed of } 10 \mathrm{~cm} / \mathrm{sec} \text {. }\end{array}$ & C \\
\hline 10 & $\begin{array}{l}\text { Raman system. How hard or brittle does the potting } \\
\text { compound get in radiation fields? }\end{array}$ & & $\begin{array}{l}\text { The Raman spectroscopy assembly and } \\
\text { associated optics have been tested for } 17 \\
\text { days in a NaOH, NaN03 and NaN02 simulant in } \\
\text { the gammaray pit. The total exposure was } \\
350,000 \text { Rad. The test results were that the } \\
\text { assembly survived the radiation and chemical } \\
\text { effects. }\end{array}$ & C \\
\hline
\end{tabular}




\begin{tabular}{|l|l|l|l|}
\hline \multirow{2}{*}{ REVIEW COMMENT RECORD (RCR) } & $\begin{array}{c}\text { 1. Date Review No. } \\
\text { June } 8,1996\end{array}$ \\
\cline { 2 - 3 } & 3. Project No. & 4. Page \\
\hline
\end{tabular}

\begin{tabular}{|c|c|c|c|c|}
\hline $\begin{array}{l}12 . \\
\text { Item }\end{array}$ & $\begin{array}{l}\text { 13. Comment (s)/Discrepancy(s) (Provide technical justification for the } \\
\text { comment and detailed recommendation of the action required to correct/ } \\
\text { resolve the discrepancy/problem indicated.) }\end{array}$ & $\begin{array}{l}14 . \\
\text { Hoid } \\
\text { Point }\end{array}$ & 15. Disposition (Provide justification if Nor accepted.) & $\begin{array}{l}16 . \\
\text { Status }\end{array}$ \\
\hline 11 & $\begin{array}{l}\text { Is the whole system weather protected - snow \& ice } \\
\text { and hot sun and dust. Maximum operating temp and } \\
\text { minimum like last winter. Max wind velocity } \\
\text { a) lowed. }\end{array}$ & & $\begin{array}{l}\text { Not all components will be exposed to the } \\
\text { environment (the control console room for } \\
\text { example is protected since it is enclosed). } \\
\text { The components outside are weather proof. } \\
\text { The components are the following: control } \\
\text { room enclosure, hydraulic ram, guide tube } \\
\text { and push rods and associated racks and the } \\
\text { trailer. These components were built to the } \\
\text { following outside environment. } \\
\text { Operating temperature: } 10 \text { to } 120{ }^{\circ} \mathrm{F} \\
\text { Storage temperature: }-40 \text { to } 120{ }^{\circ} \mathrm{F} \\
\text { Humidity: } \quad 10-100 \% \\
\text { Elevation: } \quad 0-600 \text { feet above sea level } \\
\text { Exposed equipment to withstand sand and dust }\end{array}$ & C \\
\hline 12 & $\begin{array}{l}\text { Prevent overflow of washer station in case of a } \\
\text { lollypop on the penetrometer or Guide }\end{array}$ & & $\begin{array}{l}\text { Operating procedures will require a camera } \\
\text { to be installed to verify water flow and no } \\
\text { lollipops. }\end{array}$ & 0 \\
\hline 13 & $\begin{array}{l}\text { Do we have a written step by step sequence of the } \\
\text { clamping operation }\end{array}$ & & $\begin{array}{l}\text { We only have a draft but a final version } \\
\text { will be provided by the vendor. }\end{array}$ & 0 \\
\hline 14 & $\begin{array}{l}\text { If the hydraulic clamping seals fail and the manual } \\
\text { clamp is moved can the rods or tube free fall? }\end{array}$ & & $\begin{array}{l}\text { Yes, since you have described total failure. } \\
\text { The preliminary safety assessment indicates } \\
\text { a probability of } 1 \text { x } 10^{6} \text {. The hydraulic } \\
\text { clamping system is designed to have a clamp } \\
\text { on at al1 time except when the safety system } \\
\text { is overridden (for example, when craning in } \\
\text { the guide tube, you do not want any clamps } \\
\text { in the way). At that time, you would have } \\
\text { the crane holding onto your guide tube. The } \\
\text { mechanical clamp will hold the push rod and } \\
\text { guide tube in the event that the hydraulics } \\
\text { would fail. }\end{array}$ & $C$ \\
\hline 15 & $\begin{array}{l}\text { How often is re-calibration of the instrument } \\
\text { necessary. }\end{array}$ & & $\begin{array}{l}\text { Before insertion, the sensor package will be } \\
\text { recalibrated. }\end{array}$ & ? \\
\hline
\end{tabular}

A-6400-090.1 (03/92) WEF011 


\begin{tabular}{|c|c|c|}
\hline & $\begin{array}{l}\text { 1. Date } \\
\text { June 8, } 1996\end{array}$ & 2. Revien No. \\
\hline REVIEW COMMENI RECURD (RCR) & 3. Project No. & 4. Page \\
\hline
\end{tabular}

\begin{tabular}{|c|c|c|c|c|}
\hline $\begin{array}{l}12 . \\
\text { I tem }\end{array}$ & $\begin{array}{l}\text { 13. Comment(s)/Discrepancy(s) (Provide technical just ification for the } \\
\text { coment and detailed recommendation of the action required to correct/ } \\
\text { cesolve the discrepancy/problem indicated.) }\end{array}$ & $\begin{array}{l}14 . \\
\text { Hold } \\
\text { Point }\end{array}$ & 15. Disposition (Provide justification if NOT accepted,) & $\begin{array}{l}16 . \\
\text { Status }\end{array}$ \\
\hline 16 & $\begin{array}{l}\text { The drawings need next-used on. We should be able } \\
\text { to go from the top drawing to the details and } \\
\text { subdetails parts and vice-versa. }\end{array}$ & & $\begin{array}{l}\text { WHC has requested better } \\
\text { assembly/subassembly drawings from ARA. }\end{array}$ & 0 \\
\hline 17 & Drawings need better dimensioning & & $\begin{array}{l}\text { WHC has reviewed/redlined the drawings and } \\
\text { requested that ARA fix the drawings. }\end{array}$ & 0 \\
\hline
\end{tabular}




\begin{tabular}{|l|l|l|}
\hline \multirow{2}{*}{ REVIEW COMMENT RECORD (RCR) } & $\begin{array}{r}\text { 1. Date 6/24/96 } \\
6 / 24 / 96 \\
\text { N/A }\end{array}$ & $\begin{array}{l}\text { 2. Review No. } \\
\text { CP96-019 }\end{array}$ \\
\cline { 2 - 4 } & $\begin{array}{l}\text { 3. Project Ho. Page } \\
1 \text { of } 2\end{array}$ \\
\hline
\end{tabular}

5. Document Number(s)/Title(s)
CONE PENETROMETER FINAL DESIGN CONE PE
REVIEW

17. Comment Submittal Approval:

Organization Manager (optional)

\section{Program/Project/} Building Number

CPO/CONE PEN .

7. Reviewer
M.L. MCELROY

8. Organization/Group CPQA/75820
9. Locat ion/Phone

$2704 \mathrm{HV} / \mathrm{B122/373-}$ 5588

10. Agreement with indicated comment disposition(s)

11. CLOSED

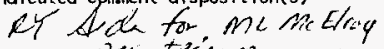

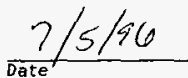

$p e r$ texes

Reviewer/Point of Contact

Reviewer/Point of Contact

Date

Author/originator

Author/originator

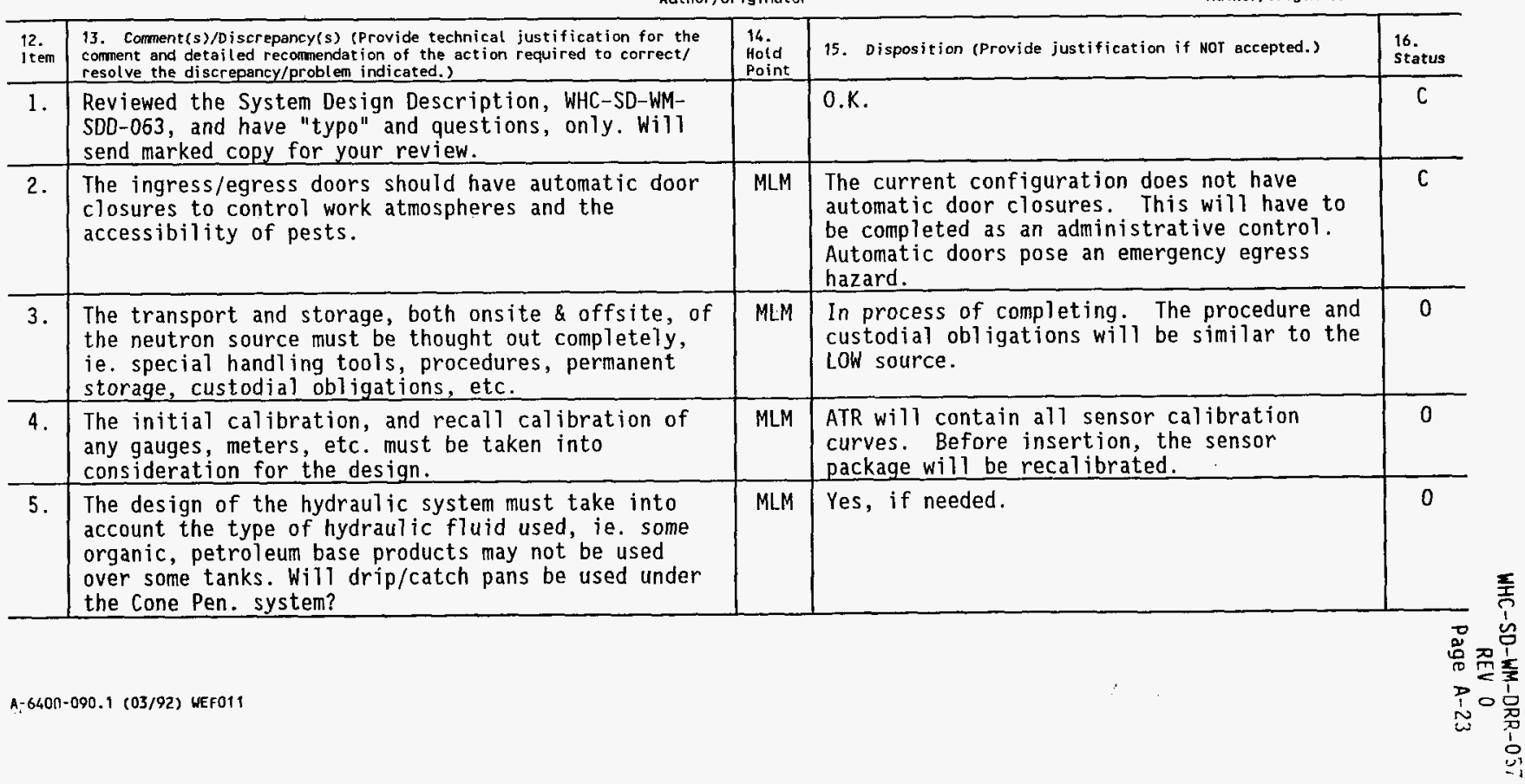




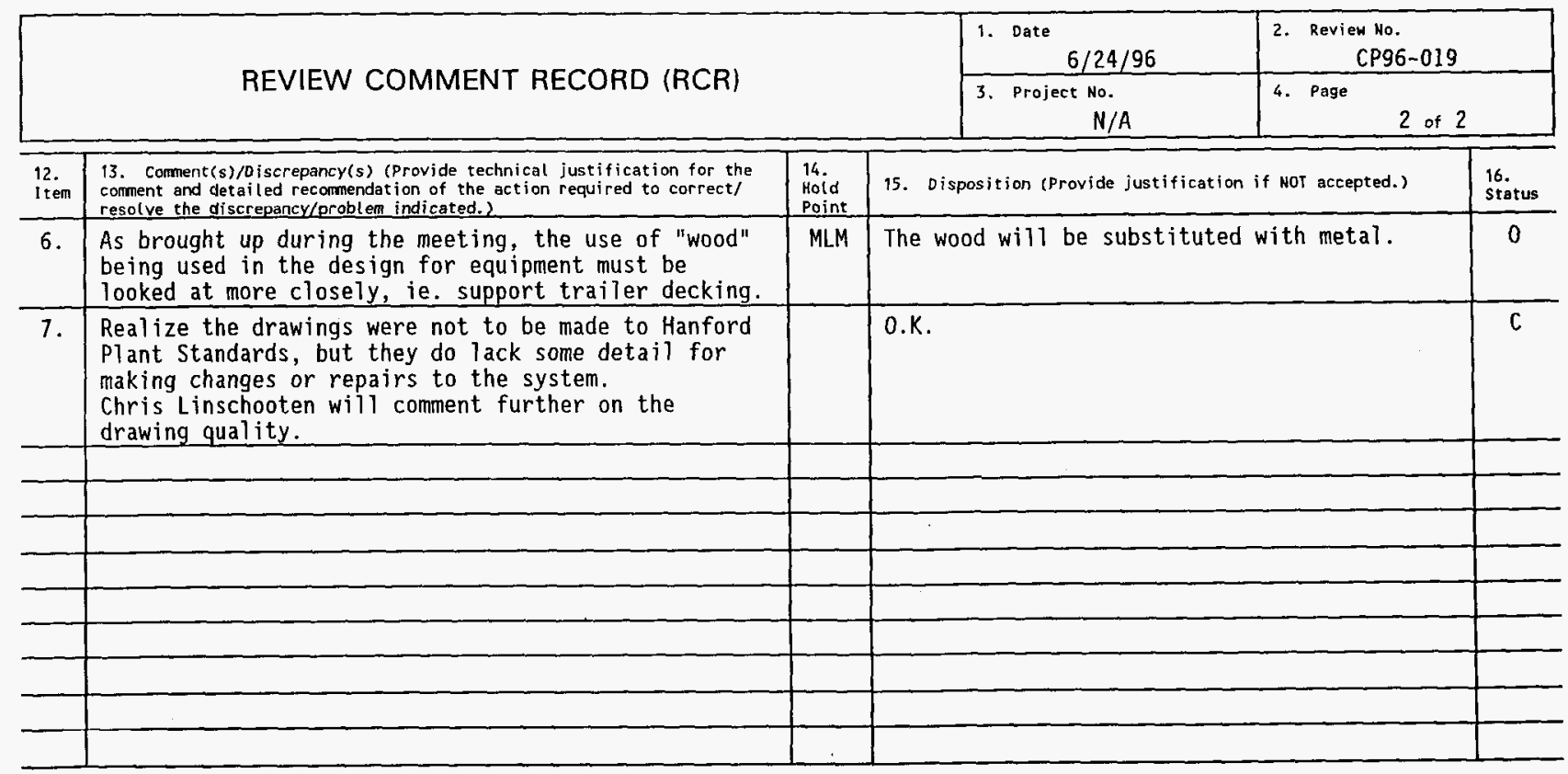


REVIEW COMMENT RECORD (RCR)

5. Document Number(s)/Title(s)

Cone Penetrometer Final Design Review

17. Comment Submittal Approval:

Organization Manager (Optional)

\begin{tabular}{l|l}
$\begin{array}{l}\text { 6. Program/Project/ } \\
\text { Building Number }\end{array}$ & 7. Reviewer \\
Cone & JH Bussell \\
Penetrometer &
\end{tabular}

10. Agreement with indicated comment disposition(s)

$7 / 266$ Date

J. Buc $\&$ C $1 /$ Reviewer/Point of contact Per tlezera
8. Organization/Group

TWRS/Eng
9. Location/Phone

$6 / 9621$

11. CLOSED

Reviewer/Point of Contact

Date

Author/originator

\begin{tabular}{|c|c|c|c|c|}
\hline $\begin{array}{l}12 . \\
\text { Item }\end{array}$ & $\begin{array}{l}\text { 13. Comment(s)/oiscrepancy(s) (Provide technical justification for the } \\
\text { comment and detailed recommendation of the action required to correct/ } \\
\text { resolve the discrepancy/problem indicated.) }\end{array}$ & $\begin{array}{l}14 . \\
\text { Hoid } \\
\text { Point }\end{array}$ & 15. Disposition (Provide justification if NOT accepted.) & $\begin{array}{l}16 . \\
\text { status }\end{array}$ \\
\hline 1 & $\begin{array}{l}\text { Standard dosimeter will indicate a higher neutron } \\
\text { dose than Hanford Neutron Combo dosimeters. Suggest } \\
\text { equiping personnel around skid with Hanford Combo. } \\
\text { Neutron dosimeters otherwise neutron doses will be } \\
\text { high because of thermal neutrons. Call me, if you } \\
\text { have any questions. }\end{array}$ & & $\begin{array}{l}\text { A radiation dose analysis is being completed } \\
\text { to determine what the operators will be } \\
\text { subjected to. These dosimeter seem to be a } \\
\text { good idea. Could you send me some } \\
\text { information on them? }\end{array}$ & 0 \\
\hline 2 & Need radiation monitors at washer gamma and beta. & & Incorporated & 0 \\
\hline 3 & Need to calculate dose rate to operator from tank. & & Incorporated & 0 \\
\hline & & & & \\
\hline & & & & \\
\hline & & & & \\
\hline & & & & \\
\hline & & & & \\
\hline & & & & \\
\hline & & & & \\
\hline & & & & \\
\hline
\end{tabular}




\section{REVIEW COMMENT RECORD (RCR)}

1. Date
June 8, 1996

3. Project No.
5. Document Number(s)/Title(s)

Cone Penetrometer Final Design Review

17. Comment Submittal Approval:

\begin{tabular}{l|l}
$\begin{array}{l}\text { 6. Program/Project/ } \\
\text { Building Number } \\
\text { Cone }\end{array}$ & 7. Reviewer \\
Penetrometer & D.J. Foust
\end{tabular}

10. Agreement with indicated comment disposition(s)

Organization Manager (Optional)

$$
\begin{aligned}
& 18 / 96 \\
& \text { DJ Foust } \\
& \text { Reviewer/Point of Contact } \\
& \text { cy fecke for DJ Foer. } \\
& \text { Author toriginator }
\end{aligned}
$$

\section{Organization/Group

\begin{tabular}{|c|c|c|c|c|}
\hline $\begin{array}{l}12 . \\
1 \text { tem }\end{array}$ & $\begin{array}{l}\text { 13. Comment(s)/D iscrepancy(s) (Provide technical justification for the } \\
\text { comment and detailed recommendation of the action required to correct/ } \\
\text { resolve the discrepancy/problem indicated.) }\end{array}$ & $\begin{array}{l}\text { P4. } \\
\text { Hoid } \\
\text { Point }\end{array}$ & 15. Disposition (Provide justification if NOT accepted.) & $\begin{array}{l}16 . \\
\text { Status }\end{array}$ \\
\hline 1 & $\begin{array}{l}\text { Wood deck and rails on support trailer are a } \\
\text { radiological control problem. The wood should be } \\
\text { replaced with a non-porous material. }\end{array}$ & & Incorporated. & 0 \\
\hline & & & & \\
\hline & & & & \\
\hline & & & & \\
\hline & & . & & \\
\hline & & & & \\
\hline & & & & \\
\hline & & & & \\
\hline & & & & \\
\hline & & & & \\
\hline & & & & \\
\hline & & & & \\
\hline & & & & \\
\hline & & & & \\
\hline
\end{tabular} \\ TWRS/CPO/ES\&H Radiological Control \\ 9. Location/Phone \\ $2704 \mathrm{HV} / 6-8215$}

Reviewer/Point of Contact

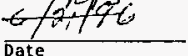

Author/originator 


\section{REVIEW COMMENT RECORD (RCR)}

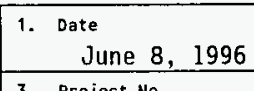

2. Review No.

3. Project No.

1 of 1

5. Docunent Number(s)/ritle(s)

Cone Penetrometer Final Design Review

17. Coment Subrnittal Approval:

Organization Manager (Optional)

\begin{tabular}{l|l}
$\begin{array}{l}\text { 6. Program/Project/ } \\
\text { Building Number } \\
\text { Cone } \\
\text { Penetrometer }\end{array}$ & 7. Reviewer \\
\hline
\end{tabular}

10. Agreement with indicated comnent disposition(s) ky deck for $L$ Draper to/27/96 Reviewer/Point of Contace L. Draper Author/originator

8. Organization/Group
TWR/TCP

11. CLOSED

$0 / 27 / 96$ Date
4. Page
9. Location/Phone

$2704 \mathrm{HV} / \mathrm{B} 117$ $2-1084$

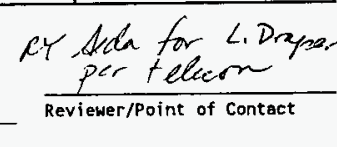

Author/Originator

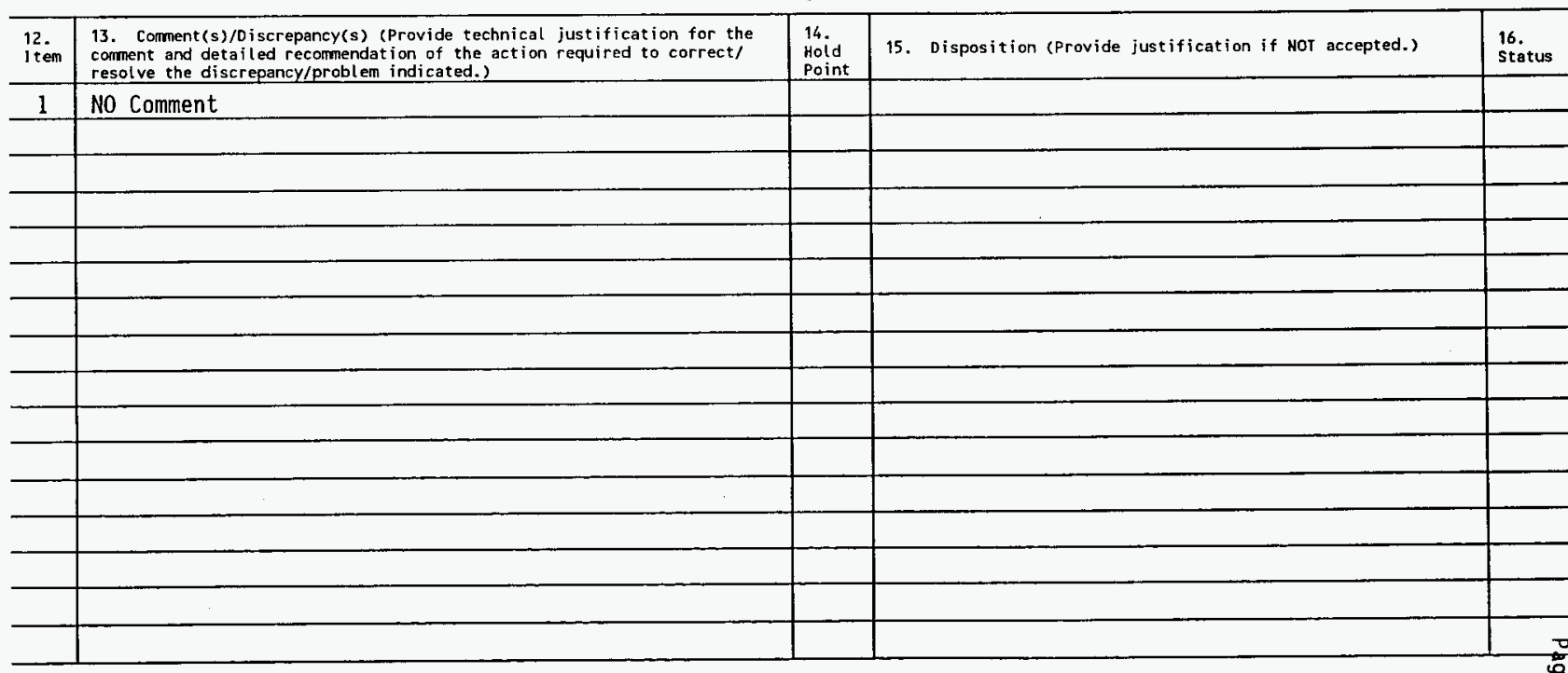


WHC-SD-WM-DRR-057

Rev 0

Page B-i

Appendix B: $60 \%$ Design Review 
TO: Distribution

BUILDING 3250 Port of Benton Road

(SAIC building)

FROM: R.Y. Seda

CHAIRMAN G.N. Boechler

Department-0peration-
Component

Char. Equipment
Area Shift Date of Meeting

$2 / 6 / 96$
Number

Attending

Distribution:

\begin{abstract}
Attendees:
\end{abstract}
L. Draper, WHC

M.L. McElroy, WHC

R.M. Nelson, WHC

J. Bajwa, WHC

D. Bowser, DOE-RL

C.E. Hanson, WHC

$T$. Thomas, INEL

M. Nolen, WHC

O. Jaka, WHC

P. Nguyen, WHC

Other: J.S. Schofield, WHC

J.S. Lee, WHC

T.R. Farris, WHC

D.W. Hamilton, WHC

The purpose of this meeting was to independently review and comment the design of the cone penetrometer to date. The system is compromised of three major components. These are the cone penetrometer platform (support trailer and skid), cone penetrometer moisture probe and cone penetrometer Raman spectroscopy system. The moisture probe has been designed and fabricated by SAIC and was being installed on the cone penetrometer skid. The Raman spectroscopy system was designed and fabricated by Lawrence Livermore National Laboratory. The attached viewgraph describe the system in its entirety.

The cone penetrometer consists of an instrumented metal rod which is pushed into the tank waste. The rod is supported by a support sleeve or guide tube which provides structural support to the rod. The rod is assembled by screwing hollow sections of the rod into the tip. The basic package consists of sensors to measure tip pressure, pore pressure and sleeve friction. Load cells at the tip (tip pressure) measure resistance of the material ahead of the tip while side load cells (friction sleeve) measure the friction as the cone pushes into the waste. Hydrostatic pressure (pore pressure) is measured by a sensing device also located within the tip. The Hanford cone penetrometer sensor package includes the basic package plus an inclinometer, redundant bottom detection system and two temperatures gauges (side and tip). A proposed Raman spectroscopy sensor will be located behind the standard package for chemical speciation. 
The tank interior has been classified as a NEC Class 1 Division 1 environment. In order to fulfill this requirement, the system has been designed to meet the requirements outlined for a NEC Class 1 Division 1 environment by either using intrinsically safe equipment or housing the equipment in an explosion proof housing. Instrumentation safety barriers are UL listed. The instruments which are intrinsically safe are the tip and side load cells, tip and side thermistors, two axis electrolytic potentiometer sensor for inclination, the redundant giant magnetoresistive ratio sensor for bottom detection and the fiberoptic Raman spectroscopy sensor. A report has been issued which addresses how the system fulfill the requirements.

The Raman spectroscopy sensor determines unknown chemical constituents via the chemical vibrational spectra. A near-infrared, mode stabilized semiconductor laser shines light into the radiation hardened fiberoptic cable. The light shines into the waste via a diamond coated sapphire window, which provides a transparent viewing port to the waste. A silvered hypotenuse right angle prism connects the optical axis of the probe window with the optical axis of the vertical penetrometer. Light is reflected or scattered into the waste. A small shift in frequency occurs when the molecules reflect or scatter the light. The shift occurs when the molecule undergoes a vibrational transition at a characteristic frequency when reflecting or scattering a light wave. The input and output are collimated (the parallel light rays from the laser beam are either expanded or shrunk), with focussing of the excitation laser beam and the returning Raman signals. The returning Raman signals are collected with seven fiber optic cables and filtered through a long pass filter to remove scattered laser light. A monochromater emits a range of wavelengths to the charge coupled device (CCD), which is employed as a Raman signal detector. A computer is used to analyze the spectra collected from the CAD. Relative concentrations can be deduced from these measurements.

The moisture probe changes were reviewed. The moisture probe system final design has been previously reviewed by safety, QA and WHC engineering. The changes consists of adding surface moisture capabilities to the system. For tank profiles, two B-10 neutron detectors are used while for surface measurements, one B-10 neutron detector is used. Test were run to calibrate the system for surface moisture measurement.

Final design details will be reviewed in the $100 \%$ design review. The final design review is scheduled for March 1996. Attached are viewgraph of the presentations.
REV 0

Page B-2 


\section{REVIEW COMMENT RECORD (RCR)}

\begin{tabular}{|l|l|}
\hline \begin{tabular}{l} 
1. $\begin{array}{l}\text { Oate } \\
\text { February 6, 1996 }\end{array}$ \\
\hline 3. Project No.
\end{tabular} & 4. Page \\
\hline
\end{tabular}

\section{Document Number(s)/Title(s) \\ Cone Penetrometer 60\% Design Review}

17. Comment Subnittal Approval:

Organization Manager (Optional)

\begin{tabular}{l|l|l}
$\begin{array}{l}\text { 6. Program/Project/ } \\
\text { Building Number } \\
\text { Cone } \\
\text { Penetrometer }\end{array}$ & $\begin{array}{l}\text { 7. Reviewer } \\
\text { J.H. Bussell }\end{array}$ & 8. or \\
\hline 10. Agreement with indicated comment disposition(s) \\
\hline
\end{tabular}

Author/Originator
8. Organization/Group

9. Location/Phone

6-9671
11. CLOSED

\section{$3 / 5 / 4<$}

Date

QY Alede for

TH Bussetiper

ic mail

Reviewer/Point of Contact

\begin{tabular}{|c|c|c|c|c|}
\hline \multicolumn{5}{|c|}{ Author/Originator } \\
\hline $\begin{array}{l}12 . \\
1 \text { tem }\end{array}$ & $\begin{array}{l}\text { 13. Comment(s)/Discrepancy(s) (Provide technical justification for the } \\
\text { comment and detailed recommendation of the action required to correct/ } \\
\text { resolve the discrepancy/problem indicated.) }\end{array}$ & $\begin{array}{l}14 . \\
\text { Hold } \\
\text { Point }\end{array}$ & 15. Disposition (Provide justification if NOT accepted.) & $\begin{array}{l}16 . \\
\text { Status }\end{array}$ \\
\hline 1 & $\begin{array}{l}\text { Radiation testing of Raman to } 200 \text { kRads should be } \\
\text { broke up in increments to determine failure point. }\end{array}$ & & $\begin{array}{l}\text { The total exposure for the cone penetrometer } \\
\text { is } 302.4 \text { kRad for } 2 \text { weeks (assuming } 900 \\
\text { Rad/h). Part studies by Robert Donahoe } \\
\text { (1994) at LANL showed a maximum signal loss } \\
\text { of } 21 \% \text { after exposure to } 532.5 \text { KRad gamma } \\
\text { radiation. The darkening was due to the } \\
\text { formation of colore centers in the glass } \\
\text { fiber, lenses and filters. The dielectric } \\
\text { coating on the filters was unaffected. The } \\
\text { report concluded that the reduced signal } \\
\text { associated with the exposure of the } \\
\text { integrated raman probe at } 177.5 \text { Rad/min does } \\
\text { not appear to be a critical factor in the } \\
\text { Hanford waste tank environment. No losses } \\
\text { are expected during the testing, so } \\
\text { increments of } 200 \text { Rad are not necessary. }\end{array}$ & \\
\hline 2 & $\begin{array}{l}\text { Pipe handling areas should be painted with paint or } \\
\text { coatings that can be decontaminated }\end{array}$ & & $\begin{array}{l}\text { The push rod nor the guide tube are planned } \\
\text { to be painted or coated at this point. The } \\
\text { clamps on the push rod and guide tube most } \\
\text { likely will be removing any paint or coating } \\
\text { on these pipes. The portions which contact } \\
\text { the waste in the push rod and guide tube are } \\
\text { expected to be disposed. }\end{array}$ & 号 \\
\hline
\end{tabular}




\section{REVIEW COMMENT RECORD (RCR)}

1. Date
February 6,1996

3. Project No.
2. Review No.

4. Page

\section{Document Mumber(s)/Title(s)}

Cone Penetrometer 60\% Design Review

17. Comment Submittal Approval:

Organization Manager (Optional)

6. Program/Project/
Building Number
Cone
Penetrometer

10. Agreement with indicated comment disposition(s)

\section{Reviewer}

G. Abatt
8. Organization/Group

ICF KH

$$
\begin{aligned}
& \text { RY Seich for } \\
& \text { Reviewer/Point of Contact } \\
& \text { Author/originator }
\end{aligned}
$$

14

Hoid

Hold resolve the discrepancy/problem indicated.)

1 A crane is to be used for moving the $C P$ sureled removing the push rod and guide tube. Have the loads imposed on the tank by the crane during the operations been addressed?
15. Disposition (Provide justification if NOI accepted.)

Yes, as far as locating the crane outside the tank (20 feet away from the tank).

\section{CLOSED \\ $3 / 11 / 96$ \\ Date}

9. Location/Phone

ETC2/6-5574

\begin{tabular}{|l|l|l|} 
& $\begin{array}{l}\text { Yes, as far as locating the crane outside } \\
\text { the tank (20 feet away from the tank). }\end{array}$ & \\
\hline & & \\
\hline & & \\
\hline & & \\
\hline & & \\
\hline
\end{tabular}




\begin{tabular}{|l|l|l|}
\hline \multirow{2}{*}{ REVIEW COMMENT RECORD (RCR) } & $\begin{array}{l}\text { 1. Oate } \\
\text { February 6, 1996 }\end{array}$ & 2. Review No. \\
\cline { 2 - 4 } & 3. Project No. & 4. Page \\
\hline
\end{tabular}

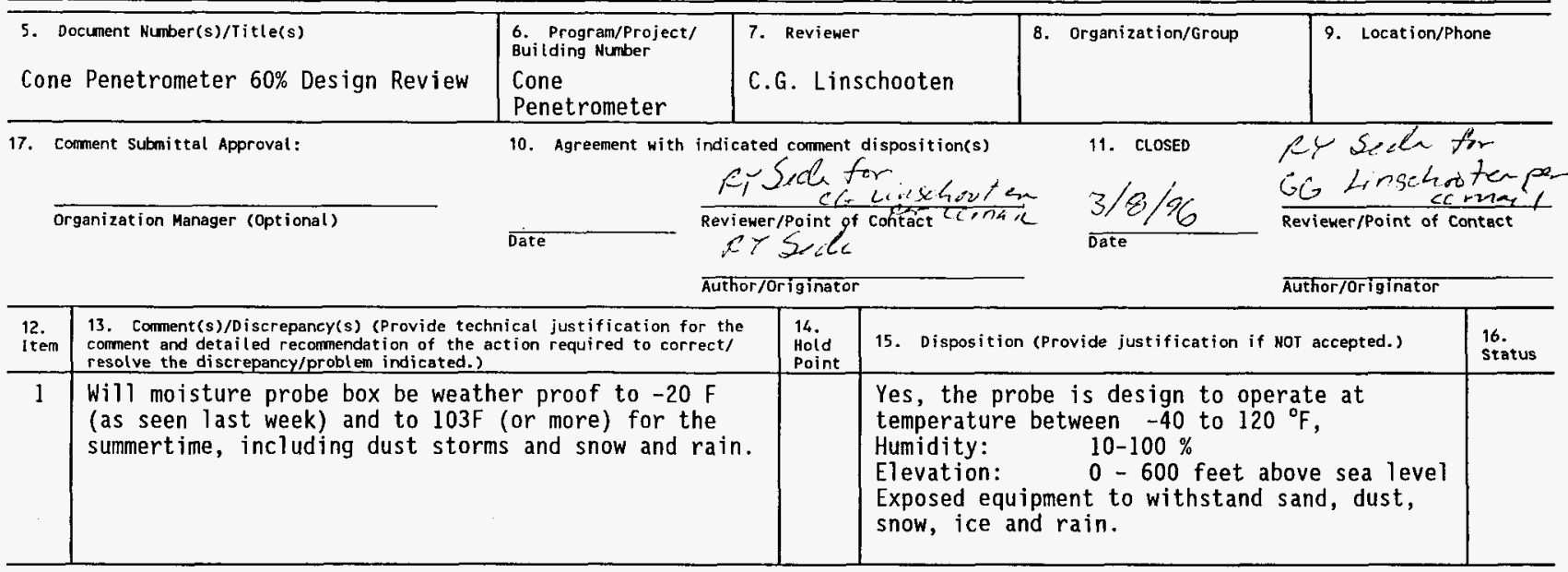




\begin{tabular}{|l|l|l|l|}
\hline \multirow{2}{*}{ REVIEW COMMENT RECORD (RCR) } & $\begin{array}{l}\text { 1. Date } \\
\text { February } 6,1996\end{array}$ & \begin{tabular}{l} 
Review No. \\
\cline { 2 - 3 }
\end{tabular} & 3. Project No. \\
\hline
\end{tabular}

\begin{tabular}{|c|c|c|c|c|}
\hline $\begin{array}{l}12 . \\
\text { I tem }\end{array}$ & $\begin{array}{l}\text { 13. Comment(s)/Discrepancy(s) (Provide technical justification for the } \\
\text { comment and detailed recommendation of the action required to correct/ } \\
\text { resolve the discrepancy/problem indicated.) }\end{array}$ & $\begin{array}{l}14 . \\
\text { Hoid } \\
\text { Point }\end{array}$ & 15. Disposition (Provide justification if NOI accepted.) & $\begin{array}{l}16 . \\
\text { status }\end{array}$ \\
\hline 2 & $\begin{array}{l}\text { Bottom detection sensor. Can it differentiate } \\
\text { between bottom of tank } 1 \text { iner and heavy metals on the } \\
\text { bottom of the tank. How accurate and reliable is } \\
\text { it? }\end{array}$ & & $\begin{array}{l}\text { There are three systems used to measure the } \\
\text { bottom of the tank. These are: depth gage, } \\
\text { tip gage and the magnetometer. The depth } \\
\text { gage is the gage used to verify that your } \\
\text { push rod does not exceed the maximum depth } \\
\text { of the tank. The same administrative } \\
\text { controls that the core sample truck uses } \\
\text { will be in place with the cone penetrometer } \\
\text { (putting in only what you need as far as } \\
\text { push rod). The tip gage measures the force } \\
\text { on the tip and compares it to the allowable } \\
\text { stresses based on some analysis done on the } \\
\text { tanks (the report is over } 400 \text { pages long). } \\
\text { The magnetometer detects the presence of } \\
\text { ferrous metals from as far as } 6-8 \text { inches. } \\
\text { As long as your material is not ferrous, it } \\
\text { can differentiate it. }\end{array}$ & \\
\hline 3 & $\begin{array}{l}\text { What is the guide tube size and length of individual } \\
\text { pieces. How does the membrane work? }\end{array}$ & & $\begin{array}{l}\text { The guide tube is } 3.5 \text { and } 6.00 \text { inches in } \\
\text { diameter (two sizes). The } 3.5 \text { guide tube is } \\
22.31 \text { inches long and the } 6.00 \text { guide tube is } \\
26.41 \text { inches long. The membrane design has } \\
\text { not been finalized. The membrane will be } \\
\text { attached at the end of the guide tube and } \\
\text { will seal the guide tube until the push rod } \\
\text { penetrates it. }\end{array}$ & \\
\hline 4 & $\begin{array}{l}\text { If the craft refuses to let the vendor operate, are } \\
\text { we ready to train our own craft in time? }\end{array}$ & & $\begin{array}{l}\text { The operational specification is currently } \\
\text { being worked out between operations. }\end{array}$ & \\
\hline 5 & $\begin{array}{l}\text { I would like to see drawings with more practical } \\
\text { tolerances. And better as-built drawings. Radii } \\
\text { and chamfers are missing. Weld call-out full weld } \\
\text { and part is skip welded (moisture probe drawings). }\end{array}$ & & $\begin{array}{l}\text { We are trying to obtain better drawings from } \\
\text { the vendor. }\end{array}$ & \\
\hline
\end{tabular}




\begin{tabular}{|c|c|c|}
\hline & $\begin{array}{l}\text { 1. Date } \\
\text { February 6, } 1996\end{array}$ & 2. Review No. \\
\hline REVIEV LUIVIVIEN I RELURU (RLR) & 3. Project No. & 4. Page \\
\hline
\end{tabular}

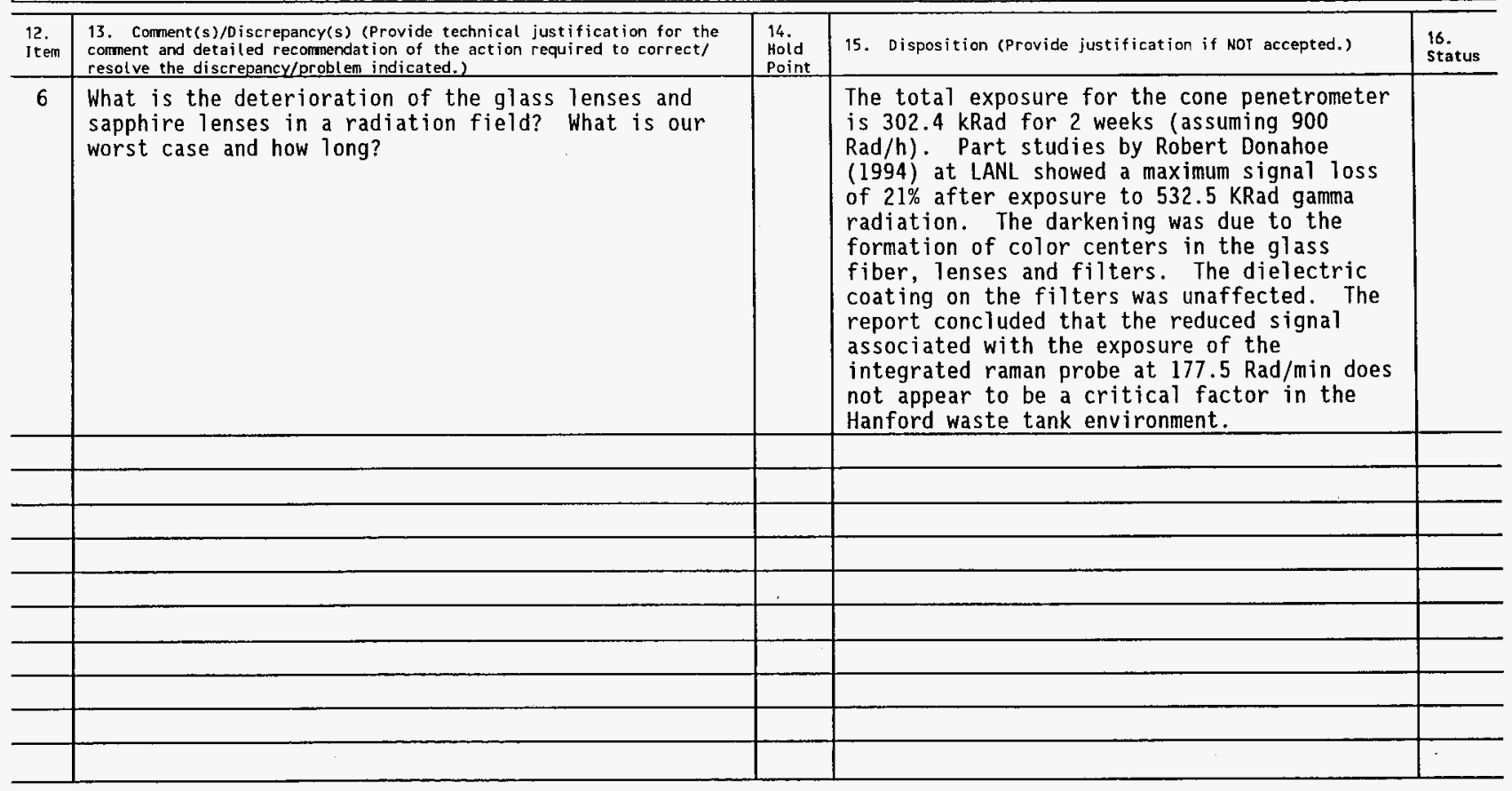




\section{REVIEW COMMENT RECORD (RCR)}

\begin{tabular}{|l|l|}
\hline \begin{tabular}{l} 
1. $\begin{array}{l}\text { Oate } \\
\text { February 6, 1996 }\end{array}$ \\
\hline 3. Project No.
\end{tabular} & 4. Page $\quad 1$ of 1 \\
\hline
\end{tabular}

5. Document Number(s)/Title(s)

\begin{tabular}{l|l}
$\begin{array}{l}\text { 6. Program/Project/ } \\
\text { Building Number } \\
\text { Cone }\end{array}$ & 7. Reviewer \\
Penetrometer & R.E. Raymond
\end{tabular}

8. Organization/Group

9. Location/Phone

Cone Penetrometer 60\% Design Review Penetrometer

CEE

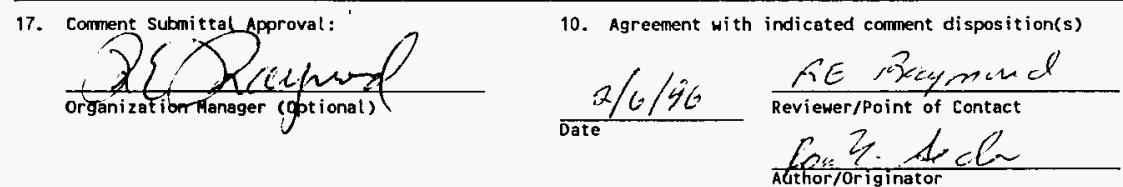$$
2 / 6 / 46
$$$$
\text { Ex: 2. An C }
$$

\begin{tabular}{|c|c|c|c|c|}
\hline $\begin{array}{l}12 . \\
\text { Item }\end{array}$ & $\begin{array}{l}\text { 13. Corment( }(s) / 0 \text { iscrepancy(s) (Provide technical justification for the } \\
\text { comment and detailed recormendation of the action required to correct/ } \\
\text { resolve the discrepancy/problem indicated.) }\end{array}$ & $\begin{array}{l}14 . \\
\text { Hoid } \\
\text { Point }\end{array}$ & 15. Disposition (Provide justification if NOT accepted.) & $\begin{array}{l}16 . \\
\text { status }\end{array}$ \\
\hline 1 & $\begin{array}{l}\text { Delete the FeCN } D Q 0 \text { from your design criteria list. } \\
\text { The FeCN safety issue is scheduled for completion in } \\
\text { May and the data needs are redundant with other DQOS }\end{array}$ & & DONE. & \\
\hline 2 & $\begin{array}{l}\text { Add the "Historical Tank Content" DQO to your } \\
\text { criteria list. }\end{array}$ & & DONE. & \\
\hline 3 & $\begin{array}{l}\text { Please conduct a systems engineering mission } \\
\text { analysis diagram - see me for details. }\end{array}$ & & A mission analysis is being completed. & 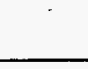 \\
\hline 4 & $\begin{array}{l}\text { If you can increase the controlled operator } \\
\text { environment. }\end{array}$ & & What is the question? & \\
\hline 5 & Do not use lead - creates mixed waste. & & $\begin{array}{l}\text { The lead will be poured into steel boxes, so } \\
\text { that no mixed waste will generated. }\end{array}$ & \\
\hline & & & & \\
\hline & & & & \\
\hline & & & & \\
\hline & & & & \\
\hline & & & & \\
\hline & & & & \\
\hline & & & & \\
\hline
\end{tabular}




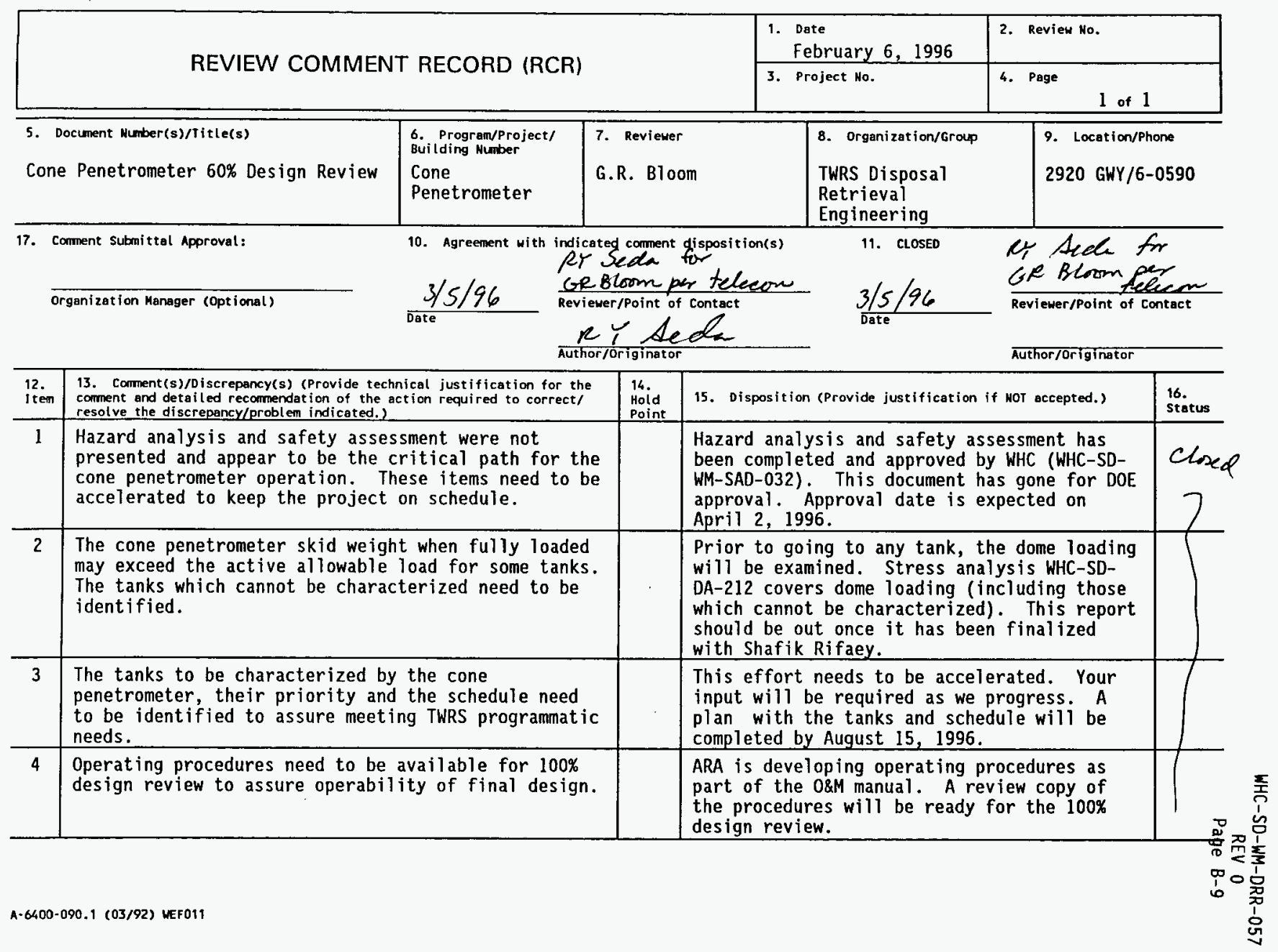




\begin{tabular}{|l|l|l|l|}
\hline REVIEW COMMENT RECORD (RCR) & $\begin{array}{l}\text { 1. Date } \\
\text { February 6, } 1996\end{array}$ & $\begin{array}{l}\text { 2. Review No. } \\
\text { 3. Project No. }\end{array}$ & 4. Page \\
\end{tabular}

\begin{tabular}{|c|c|c|c|c|}
\hline $\begin{array}{l}12 . \\
\text { item }\end{array}$ & $\begin{array}{l}\text { 13. Comment(s)/Discrepancy(s) (Provide technical justification for the } \\
\text { comment and detailed recommendat ion of the action required to correct/ } \\
\text { resolve the discrepancy/problem indicated.) }\end{array}$ & $\begin{array}{l}14 . \\
\text { Moid } \\
\text { Point } \\
\end{array}$ & 15. Disposition (Provide justification if NOr accepted.) & $\begin{array}{l}16 . \\
\text { status }\end{array}$ \\
\hline 5 & $\begin{array}{l}\text { The sensor probe instrument connector design needs } \\
\text { to assure inadvertent disconnection during probe } \\
\text { insertion. }\end{array}$ & & $\begin{array}{l}\text { The current design will be tested to verify } \\
\text { this does not occur. }\end{array}$ & 7 \\
\hline 6 & $\begin{array}{l}\text { Radiation fields above riser need to be determined } \\
\text { and considered in assuring operator safety during } \\
\text { operation over tanks like SY-102 \& } 101 \text { which have } \\
\text { higher radiation fields. }\end{array}$ & & $\begin{array}{l}\text { The radiation exposure for the cone } \\
\text { penetrometer will be no more than that of } \\
\text { the current rotary core sample truck. An } \\
\text { analysis will be presented at the } 100 \% \\
\text { design review, which will occur at the end } \\
\text { of March. }\end{array}$ & \\
\hline 7 & $\begin{array}{l}\text { Alignment procedures need to be specified for } \\
\text { platform and alignment box positioning over riser. }\end{array}$ & & $\begin{array}{l}\text { Operating procedures will be included for } \\
\text { these steps. }\end{array}$ & \\
\hline 8 & $\begin{array}{l}\text { Steel probe contact with guide tube contact should } \\
\text { be evaluated as a spark source. }\end{array}$ & & $\begin{array}{l}\text { This has been evaluated and has been } \\
\text { determine that it is of no consequence (see } \\
\text { E[S-W-96-447). }\end{array}$ & \\
\hline 9 & $\begin{array}{l}\text { Correlations between CPT data and rheological } \\
\text { properties need to be confirmed before full scale } \\
\text { operation. }\end{array}$ & & $\begin{array}{l}\text { Further testing, in April, will confirm the } \\
\text { properties. WHC-SD-WM-ATP-146 wi11 cover } \\
\text { the tests. }\end{array}$ & \\
\hline & & & & \\
\hline & & & & \\
\hline & & & & \\
\hline & & & & \\
\hline & & & & \\
\hline & & & & \\
\hline & & & & 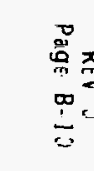 \\
\hline
\end{tabular}




\section{REVIEW COMMENT RECORD (RCR)}

\begin{tabular}{|l|l|}
\hline $\begin{array}{l}\text { 1. Date } \\
\text { February 6, 1996 }\end{array}$ & 2. Review No. \\
\hline 3. Project No. & 4. Page $\quad 1$ of l \\
\hline
\end{tabular}

\section{Document Number(s)/Title(s) \\ Cone Penetrometer 60\% Design Review}

17. Comment Submittal Approval:

6. Programbroject/
Buil lding Number
Cone
Penetrometer

10. Agreement with indicated coment disposition(s)

Agreement with indicated goment dispos

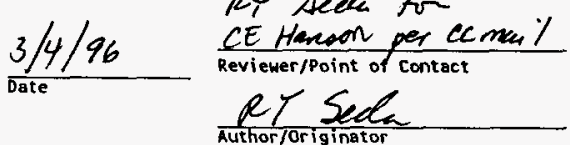

8. Organization/Group

CED
9. Location/Phone

H5-09/6-4810

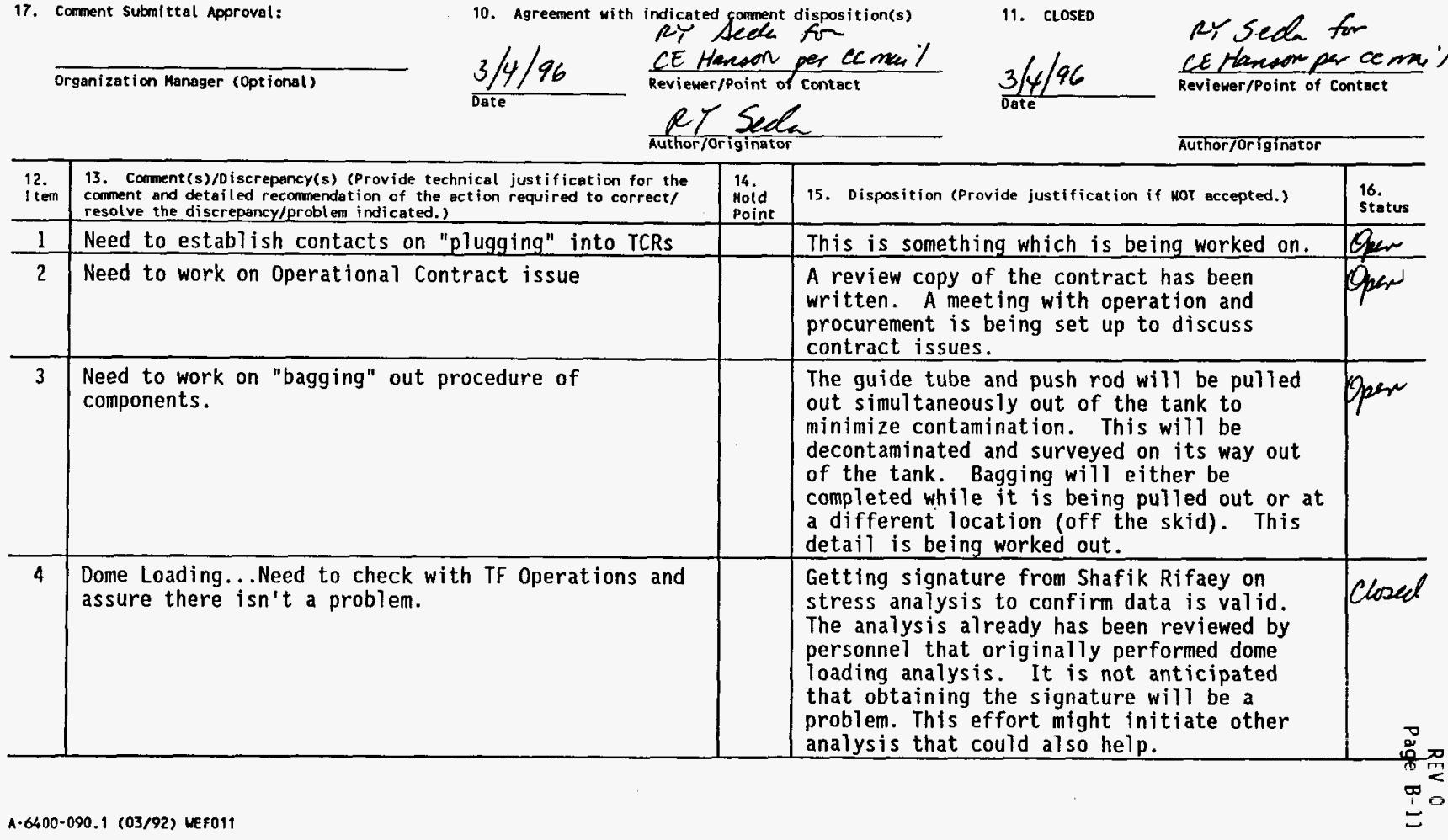

11. CLOSED

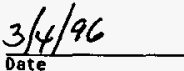

\section{Rereda tor} Reviewer/Point of Contact 


\section{REVIEW COMMENT RECORD (RCR)}
1. Date
February 6, 1996

3. Project No.
2. Revien No.

4. Page

2 of 1

\begin{tabular}{|c|c|c|c|c|}
\hline $\begin{array}{l}12 . \\
\text { I ten }\end{array}$ & $\begin{array}{l}\text { 13. Comment(s)/Discrepancy(s) (Provide technical justificat ion for the } \\
\text { comment and detai led recommendat ion of the action required to correct/ } \\
\text { resolve the discrepancy/problem indicated.) }\end{array}$ & $\begin{array}{l}14 . \\
\text { Hoid } \\
\text { Point }\end{array}$ & 15. Disposition (Provide justification if NOT accepted.) & $\begin{array}{l}16 . \\
\text { Status }\end{array}$ \\
\hline 5 & $\begin{array}{l}\text { Need to get through set up with operations and crane } \\
\text { and rigging and get refined procedure. }\end{array}$ & & Working on it. & \\
\hline & & & & \\
\hline & & & & \\
\hline & & & & \\
\hline & & & & \\
\hline & & & & \\
\hline & & & & \\
\hline & & & & \\
\hline & & & & \\
\hline & - & & & \\
\hline & & & & \\
\hline
\end{tabular}




\section{REVIEW COMMENT RECORD (RCR)}

\section{Date}

February 6, 1996

3. Project mo.
2. Review No.

4. Page

1 of 1
5. Document Nuber(s)/litle(s)

Cone Penetrometer 60\% Design Review

\section{Comment submittal Approval}

Organization Manager (optional)

\begin{tabular}{l|l}
$\begin{array}{l}\text { 6. Program/Project/ } \\
\text { Building Number } \\
\text { Cone } \\
\text { Penetrometer }\end{array}$ & 7. Reviewer \\
\end{tabular}

10. Agreement with indicated comment disposition(s)

\section{a. Organization/Group \\ SAIC TFA}

9. Location/Phone

$372-7756$

11. CLOSED

\section{Revieuer/Point of Contect}

Author/Originator
Date
Reviewer/Point of Contact

Author/originato

\begin{tabular}{|c|c|c|c|c|}
\hline $\begin{array}{l}12 . \\
1 \text { tem }\end{array}$ & $\begin{array}{l}\text { 13. Comment(s)/oiscrepancy(s) (Provide technical justification for the } \\
\text { coment and detailed recommendation of the oction required to correct/ } \\
\text { resolve the discrepancy/problem indicated.) }\end{array}$ & $\begin{array}{l}14 \text {. } \\
\text { Hoid } \\
\text { Point }\end{array}$ & 15. Disposition (Provide justiflication if wot accepted.) & $\begin{array}{l}16 . \\
\text { status }\end{array}$ \\
\hline & 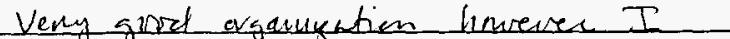 & & & \\
\hline & 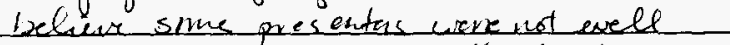 & & & \\
\hline & prepared on cervfouidian itt the torns. & & & \\
\hline & & & & \\
\hline & & & & \\
\hline & & & & \\
\hline & & & & \\
\hline & & & & \\
\hline & & & & \\
\hline & & & & \\
\hline & & & & \\
\hline & & & & \\
\hline & & & & \\
\hline & & & & \\
\hline & 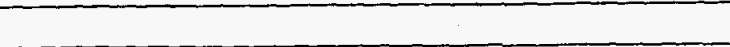 & & & \\
\hline
\end{tabular}




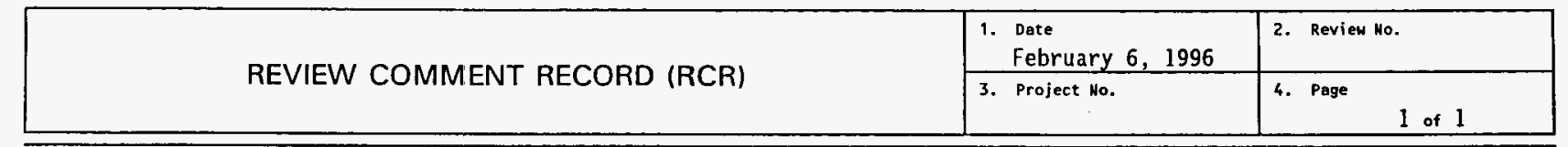

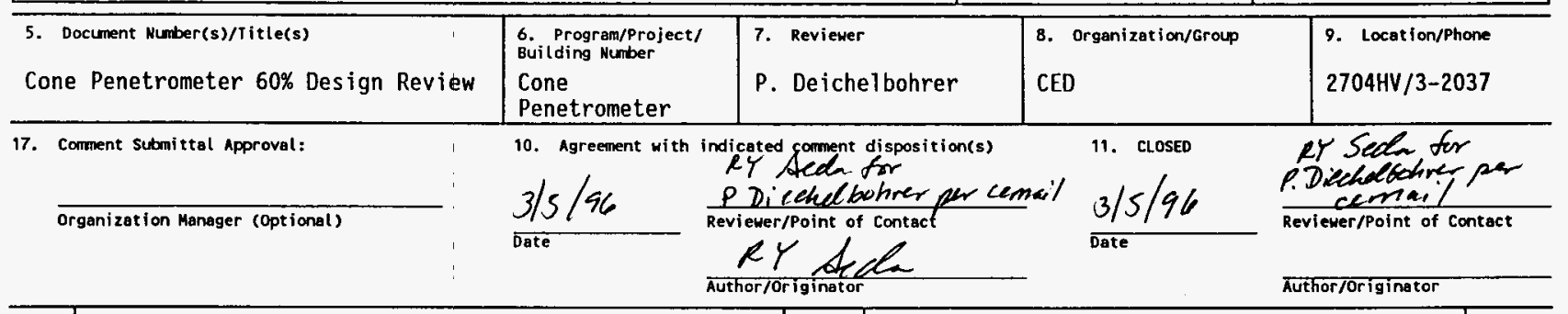

\begin{tabular}{|c|c|c|c|c|}
\hline $\begin{array}{l}12 . \\
\text { Item }\end{array}$ & $\begin{array}{l}\text { 13. Comment(s)/Discrepancy(s) (Provide technical justification for the } \\
\text { comment and detailed recommendation of the action required to correct/ } \\
\text { resolve the discrepancy/problem indicatied.) }\end{array}$ & $\begin{array}{l}14 . \\
\text { Hoid } \\
\text { Point }\end{array}$ & 15. Disposition (Provide justification if NOT accepted.) & $\begin{array}{l}16 . \\
\text { Status }\end{array}$ \\
\hline 1 & Shaft Encoder circuits & & $\begin{array}{l}\text { DONE. Geoff Barnes has given Chris } \\
\text { Linschooten this material and he was } \\
\text { supposed to share this information with you. }\end{array}$ & Clace \\
\hline 2 & Thermistor circuits & & $\begin{array}{l}\text { DONE. Geoff Barnes has given Chris } \\
\text { Linschooten this material and he was } \\
\text { supposed to share this information with you. }\end{array}$ & \\
\hline 3 & $\begin{array}{l}\text { You are going to throw away: } \\
\text { CP pipe } \\
\text { the stabilizer } \\
\text { the tip instrumentation } \\
\text { the Raman probe } \\
\text { the cable/fibering, etc... for each tank. will this } \\
\text { be cheaper than the rotary mode sampling? }\end{array}$ & & $\begin{array}{l}\text { The following will be thrown away: } \\
\text { Contaminated CP pipe (that has touched } \\
\text { waste), stabilizer (that has touched waste), } \\
\text { tip instrumentation, Raman probe (if } \\
\text { necessary). The saving of 300K per hole } \\
\text { comes from no laboratory analysis disposal } \\
\text { tranportation, ect... }\end{array}$ & \\
\hline 4 & $\begin{array}{l}\text { Raman probe in the } C P \text { is no substitute for lab } \\
\text { analysis of core samples. }\end{array}$ & & Lab analysis is not needed in all tanks. & \\
\hline 5 & $\begin{array}{l}\text { How are you going to prevent the operator from } \\
\text { sabotaging the operation by pulling the instrument } \\
\text { cable before the } C P \text { is fully inserted? }\end{array}$ & & Administrative controls & \\
\hline 6 & $\begin{array}{l}\text { How will ballast be transported to the tank top? } \\
\text { Crane? fork truck? }\end{array}$ & & Crane. & \\
\hline
\end{tabular}




\begin{tabular}{|c|c|c|c|c|c|}
\hline \multirow{2}{*}{\multicolumn{3}{|c|}{ REVIEW COMMENT RECORD (RCR) }} & $\begin{array}{l}\text { 1. Date } \\
\text { February 6, } 1996\end{array}$ & \multicolumn{2}{|l|}{ 2. Revieu No. } \\
\hline & & & 3. Project No. & \multicolumn{2}{|c|}{2 of 1} \\
\hline $\begin{array}{l}12 . \\
\text { item }\end{array}$ & $\begin{array}{l}\text { 13. Corment(s)/Discrepancy(s) (Provide technical justification for the } \\
\text { comment and detailed recommendation of the action required to correct/ } \\
\text { resolve the discrepancy/problem indicated.) }\end{array}$ & $\begin{array}{l}\text { Mo. } \\
\text { Hold } \\
\text { Point }\end{array}$ & \multicolumn{2}{|c|}{ 15. Disposition (Provide justification if NOT accepted,) } & $\begin{array}{l}\text { 16. } \\
\text { Status }\end{array}$ \\
\hline 7 & $\begin{array}{l}\text { How are you going to get } Q A \text { to approve the neural } \\
\text { network resuits? }\end{array}$ & & \multicolumn{2}{|c|}{$\begin{array}{l}\text { This is the response I obtained from Kevin } \\
\text { Kyle: "Good question. In theory, we were } \\
\text { going to test the neura? network with the } \\
\text { hotcell Raman system. The problem is that } \\
\text { there is now no hot cell Raman system due to } \\
\text { loss of funding. Simulant tests will be run } \\
\text { at LLNL both during neural network training } \\
\text { and later on in bl ind testing, but I really } \\
\text { can't say how the QA will work. I'1l be } \\
\text { writing QA in as an FY97 task through CMST } \\
\text { (EM-50), giving the work to Fred Reich's } \\
\text { group or Bev Crawford's group, whoever has } \\
\text { more ready acess to the hot cell facility.; } \\
\text { This year, I am simply not funded for QA." }\end{array}$} & \\
\hline & & & & & \\
\hline & & & & & \\
\hline & & & & & \\
\hline & & & & & \\
\hline & & & & & \\
\hline & & & & & \\
\hline & & & & & \\
\hline & & & & & \\
\hline & & & & & \\
\hline
\end{tabular}




\begin{tabular}{|c|c|c|}
\hline & $\begin{array}{l}\text { 1. Date } \\
\text { February } 6,1996\end{array}$ & $\begin{array}{l}\text { 2. Revieu No. } \\
\text { CP96-010 }\end{array}$ \\
\hline REVIEV CUIVIVIEIN & 3. Project No. & 4. Page \\
\hline
\end{tabular}

\begin{tabular}{l|l|l|l|l}
\hline 5. Document Number(s)/Title(s) & $\begin{array}{l}\text { 6. Program/Project/ } \\
\text { Buitding Number } \\
\text { Cone } \\
\text { Penetrometer }\end{array}$ & $\begin{array}{l}\text { 7. Reviewer } \\
\text { M.L. McETroy }\end{array}$ & $\begin{array}{l}\text { 8. Organization/Group } \\
\text { CPE-QA }\end{array}$ & $\begin{array}{l}\text { 9. Location/Phone } \\
\text { 2704HV/3-5588 }\end{array}$ \\
\hline
\end{tabular}

17. Comment Submittal Approval:

Organization Manager (Optional)
10. Agreement with

10. Agreement with indicated corment disposition(s)
M. $2 . M \varepsilon e \cos$ Reviewer/Point of Contact
RY. Aede
11. CLOSED

M.L.MEreor $\frac{3 / 4 / 96}{\text { Date }}$

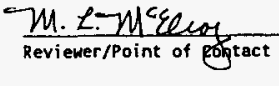

Author/0riginator

\begin{tabular}{|c|c|c|c|c|}
\hline \multicolumn{5}{|c|}{ Author/Originator } \\
\hline $\begin{array}{l}12 . \\
\text { It en }\end{array}$ & $\begin{array}{l}\text { 13. Comment(s)/Discrepancy(s) (Provide technical justification for the } \\
\text { corment and detailed recommendation of the action required to correct/ } \\
\text { resolve the discrepancy/problem indicated.) }\end{array}$ & $\begin{array}{l}14 . \\
\text { Hoid } \\
\text { Point }\end{array}$ & 15. Disposition (Provide justification if NoT accepted.) & $\begin{array}{l}16 . \\
\text { Status }\end{array}$ \\
\hline 1 & $\begin{array}{l}\text { Many risers may not be vertical, or are bent or may } \\
\text { have obstructions (welds, etc.). Will there be a } \\
\text { means of riser characterization before sampling? }\end{array}$ & & $\begin{array}{l}\text { Yes. A plug gauge similar to the one used } \\
\text { on ic installations will be used. }\end{array}$ & $C \log _{E O}$ \\
\hline 2 & $\begin{array}{l}\text { Besides the } x-y \text { movement of the push system, will } \\
\text { there be the capability for vertical tilt, if riser } \\
\text { is beyond vertical? Beyond } 5^{\circ} \text { ? }\end{array}$ & & $\begin{array}{l}\text { The leveling system could do this however. } \\
\text { the rod strength would be significantly } \\
\text { lessened. }\end{array}$ & \\
\hline 3 & $\begin{array}{l}\text { What system will there be for monitoring tank } \\
\text { parameters, i.e., hydrogen levels? S.A. } \\
\text { Requirements? }\end{array}$ & & $\begin{array}{l}\text { Same as the Core sample truck (hydrogen } \\
\text { sniffers, etc.) }\end{array}$ & \\
\hline 4 & $\begin{array}{l}\text { The OSDs and OSRs and SA are continually changing as } \\
\text { tank characterization takes place. The controls } \\
\text { from these documents must be incorporated into the } \\
\text { CP design, ie, } 30 \text { diameters of open riser must be } \\
\text { maintained for tank top electrical equipment. }\end{array}$ & & $\begin{array}{l}\text { The project is trying to stay up on the } \\
\text { changes through Dennis Hamilton and Jeff } \\
\text { Smalley. }\end{array}$ & \\
\hline 5 & $\begin{array}{l}\text { Will WHC perform ATP on site, with all interfaces } \\
\text { before sampling of any tanks. This would include } \\
\text { testing of } 0 \text { rings, procedures, software and } \\
\text { hardware. }\end{array}$ & & $\begin{array}{l}\text { WHC is planning on performing an ATP on the } \\
\text { cone penetrometer next month. This will } \\
\text { include testing of the O-rings, hardware and } \\
\text { software. From the ATP, procedures will be } \\
\text { written. }\end{array}$ & \\
\hline
\end{tabular}




\begin{tabular}{|c|c|c|c|c|c|}
\hline \multirow{2}{*}{\multicolumn{3}{|c|}{ REVIEW COMMENT RECORD (RCR) }} & $\begin{array}{l}\text { Fate } \\
\text { February } 6,1996\end{array}$ & \multicolumn{2}{|l|}{ 2. Review No. } \\
\hline & & & 3. Project No. & \multicolumn{2}{|c|}{2 of 2} \\
\hline $\begin{array}{l}12 . \\
\text { I tem }\end{array}$ & $\begin{array}{l}\text { 13. Comment(s)/Discrepancy(s) (Provide technical justification for the } \\
\text { comment and detailed recommendat ion of the action required to correct/ } \\
\text { resolve the discrepancy/problem indicated.) }\end{array}$ & $\begin{array}{l}\text { 14. } \\
\text { Hold } \\
\text { Point }\end{array}$ & \multicolumn{2}{|c|}{ 15. Disposition (Provide justification if NOT accepted.) } & $\begin{array}{l}16 . \\
\text { Status }\end{array}$ \\
\hline 6 & $\begin{array}{l}\text { As an alternate removal scenario, will there be a } \\
\text { bagging system in the case of decontamination } \\
\text { failure or insufficient decontamination? }\end{array}$ & & \multicolumn{2}{|c|}{$\begin{array}{l}\text { Bagging the push rod and guide tube in the } \\
\text { event of insufficient decontamination will } \\
\text { be implemented. }\end{array}$} & \\
\hline 7 & $\begin{array}{l}\text { After data acquisition, where does the data go? Who } \\
\text { analyzes the data and reports the findings and } \\
\text { documents? }\end{array}$ & & \multicolumn{2}{|c|}{$\begin{array}{l}\text { Where the data and report is being } \\
\text { coordinated with the people who do the tank } \\
\text { sampling plans. This is a detail which is } \\
\text { currentiy being worked on. }\end{array}$} & \\
\hline 8 & $\begin{array}{l}\text { Will WHC receive copies and results of all testing? } \\
\text { i.e. pressure tests, push tests, chemical tests, } \\
\text { ect? }\end{array}$ & & \multicolumn{2}{|l|}{ Yes, this is required. } & $t$ \\
\hline & & & & & \\
\hline & & & & & \\
\hline & & & & & \\
\hline & & & & & \\
\hline & & & & & \\
\hline & & & & & \\
\hline
\end{tabular}




\section{REVIEW COMMENT RECORD (RCR)}

1. Dote
February 6, 1996

3. Project No.
2. Review Ho.

4. Page

1 of 1

\section{Document Number(s)/fitle(s)}

Cone Penetrometer 60\% Design Review

17. Comment Submittal Approval:

Organization Manager (Optional)

\begin{tabular}{l|l}
$\begin{array}{l}\text { 6. Program/Project/ } \\
\text { Building Number } \\
\text { Cone } \\
\text { Penetrometer }\end{array}$ & $T$. Reviewer \\
\hline
\end{tabular}

10. Agreement with indicated comment disposition(s)

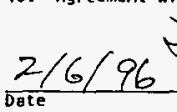

$\rightarrow$ H. 7 .

Reviewer/Point of Contact

Author/originator
8. Organizetion/Group

11. CLOSED

9. Location/Phone

ate

Reviewer/Point of Contact

Author/Originator

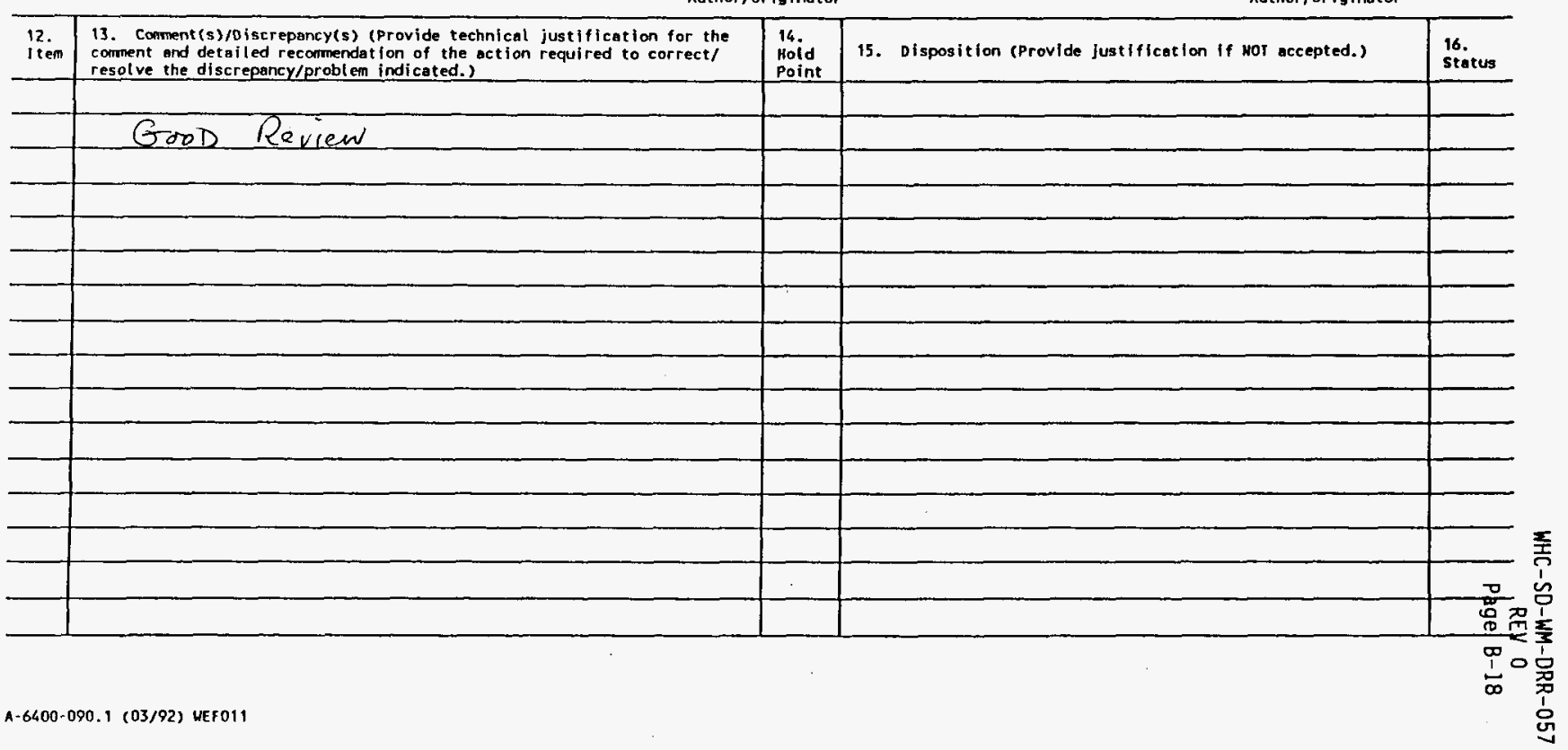




\section{REVIEW COMMENT RECORD (RCR)}

1. Date
February 6, 1996
3. Project Ho.

3. Project No.
5. Document Number(s)/Title(s)

Cone Penetrometer 60\% Design Review

Cone Penetrometer
6. Programproject/ Buil ling Number

7. Reviewer
Kevin Kyle

10. Agreement with indicated,comment disposition(s)

17. Comment Submittal Approval:

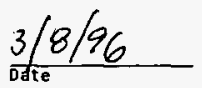

Revie

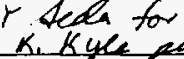

Organization Manager (Optional)

Reviewer/PGint of Contact

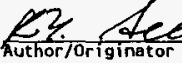

8. Organization/Group

LLNL

11. CLOSED
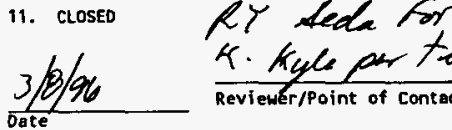

4.

Reviewer/Point of Contact
9. Location/Phone

$510-423-3693$

Author/Originato

\begin{tabular}{|c|c|c|c|c|}
\hline $\begin{array}{l}12 . \\
\text { t tem }\end{array}$ & $\begin{array}{l}\text { 13. Comment(s)/Discrepancy(s) (Provide technical justification for the } \\
\text { comment and detailed recommendation of the action required to correct/ } \\
\text { resolve the discrepancy/problem indicated.) }\end{array}$ & $\begin{array}{l}14 . \\
\text { Hold } \\
\text { Point }\end{array}$ & 15. Disposition (Provide justification if NOT accepted.) & $\begin{array}{l}16 . \\
\text { Status }\end{array}$ \\
\hline 1 & $\begin{array}{l}\text { Guide tube design: if it goes all the way to the } \\
\text { solid waste, information on surface slurrier and } \\
\text { sludges will be missed. Is it necessary for guide } \\
\text { tube to anchor in waste? }\end{array}$ & & $\begin{array}{l}\text { Since most tanks contain materials of } \\
\text { unknown strengths, it is very likely that } \\
\text { the guide tube will be installed. The guide } \\
\text { tube provides structural strength (buckling) } \\
\text { to the push rod. The maximum length of rod } \\
\text { (unsupported) which we could deploy without } \\
\text { buckling is probably } 20 \text { feet (this is in } \\
\text { slushy materials). }\end{array}$ & \\
\hline 2 & $\begin{array}{l}\text { ARA must decide on a final penetrometer pipe design. } \\
\text { The latest design are still under consideration and } \\
\text { have not been finalized. }\end{array}$ & ? & ARA has the final configuration. & \\
\hline 3 & $\begin{array}{l}\text { Organic tanks end users would like the top few feet } \\
\text { characterized for organics. Can deployment include } \\
\text { l inch push and hold intervals during collection of } \\
\text { Raman data? }\end{array}$ & & $\begin{array}{l}\text { No. A } 1 \mathrm{~cm} / \mathrm{sec} \text { push will invalidate any } \\
\text { rheological data which has been obtained. } \\
\text { Instead, a scheme in which the push rod is } \\
\text { pushed and stopped (every } 6 \text { inches) can be } \\
\text { implemented. }\end{array}$ & \\
\hline & & & & \\
\hline & & & & \\
\hline & & & & \\
\hline & & & & \\
\hline & & & & \\
\hline
\end{tabular}


WHC-SD-WM-DRR-057

Rev 0

Page C-i

Appendix C: 30\% Design Review 
Subject: Cone Penetrometer 30\% Design Review

T0: Distribution

BUILDING 3250 Port of Benton Road

(SAIC building)

FROM: R.Y. Seda

CHAIRMAN G.N. Boechler

Department-0peration-
Component

Char. Equipment
Area Shift Date of Meeting

9/6/95
Number

Attending

21

Distribution:

Attendees:

other:
W. Bratton, ARA

J. Shinn, ARA

F.P. Johansen, SAIC

C.G. Linschooten, WHC

M.L. MCElroy, WHC

F.G. Abatt, KEH

J.E. Kane, WHC

J.K. Bajwa, WHC

F.M. Jones, WHC

R.L. Butler, WHC

P.R. Hernandez, DOE-RL
P.R. Deichelbohrer, WHC

J.H. Bussel1, WHC

R.L. Hand, WHC

R.M. Nelson, WHC

J.M. Silko, DOE-RL

C.E. Hanson, WHC

L.S. Krogrud, WHC

J.P. StrehIow, WHC

R.Y. Seda, WHC

G.N. Boechler, WHC

D.W. Bowser, DOE-RL

J.S. Schofield, WHC

J.S. Lee, WHC

T.R. Farris, WHC

R.E. Raymond, WHC

D.W. Hamilton, WHC

G.T. Dukelow, WHC

The purpose of the meeting was to discuss the preliminary design of the skid mounted cone penetrometer. Applied Research Associates (ARA) presented the design while Science Application International Corporation (SAIC) presented the operation of the moisture probe. The cone penetrometer system consists of the CPT skid and its support trailer.

The cone penetrometer consists of an instrumented metal rod which is pushed into the tank waste. The rod is supported by a support sleeve or guide tube which provides structural support to the rod. The rod is assembled by screwing hollow sections of the rod into the tip. The basic package consists of sensors to measure tip pressure, pore pressure and sleeve friction. Load cells at the tip (tip pressure) measure resistance of the material ahead of the tip while side load cells (friction sleeve) measure the friction as the cone pushes into the waste. Hydrostatic pressure (pore pressure) is measured by a sensing device also located within the tip. The Hanford cone penetrometer sensor package includes the basic package plus an inclinometer, redundant bottom detection system and two temperatures gauges (side and tip). A proposed Raman spectroscopy sensor will be located behind the standard package. The purpose of this sensor is for chemical speciation. 
The basic operation of the system entails first installing the guide tube, and then the push rod. The cable bundle is removed such that a 1.00 inch hole is left. The moisture probe then surveys the tank to obtain surface moisture and temperature and moisture content profiles. Testing has been completed on both the moisture probe and cone penetrometer. For test results, please contact Rosa Seda.

The basic operation of the cone penetrometer system as follow:

\section{Riser preparation}

This is a routine activity performed prior to the installation of the cone penetrometer to verify riser availability and ensure that there are no obstructions for installation and operation of the cone penetrometer. This inspection will provide the following detailed information:

* Zip cord measurements to provide distance from top of the riser to waste surface and riser length measurements.

* Video camera footage to provide a view of the inside of the tank and in particular, the waste surface below the riser.

* For 4" risers, the riser will be measured for diameter, ovality and straightness of the riser.

2. Installation, Operation and Removal:

\section{POSITION SKID AND SET-UP:}

* Install riser adapter and decontamination unit

* Place skid over riser using crane (legs fully extended)

* Ground all equipment

* Position support trailer (off the tank) and connect to skid

* Level skid

* Position $X-Y$ to within \pm 0.25 inches of riser center

* Ballast as required

INSTALL GUIDE TUBE:

* Assemble Guide tube to length required to reach top of waste

* Lower Guide tube in place with crane

* Assemble push rod and begin cone penetrometer push (about 4 feet into the waste)

* Push guide tube so that it seats into the hard waste (about 26 inches into the waste). The guide tube will be assembled only if a hard push (i.e., 35 tons) is required.

* Continue cone penetrometer push

\section{CONDUCT PENETRATION:}

* Push cone penetrometer into waste

* Data acquisition system collects data during push

* Data acquisition system monitors all safety conditions

* Reach end condition (tank bottom)

* Disconnect electrical cable from probe

* Conduct moisture and temperature survey 
* Start decontamination system

* Attach coupler - allow crane to lift both rod and guide tube at the same time. Decontaminate equipment.

* Cover with plastic containment sleeve and monitor radiation levels using standard tank farm techniques while removing from the riser. Guide tube and push rod will be broken down prior to bagging of equipment. Dispose of guide tube and push rod.

* Seal riser.

\section{TEST COMPLETION:}

\section{* Remove unit to lowboy for transport \\ * Analyze Data \\ * Prepare report \\ * Prepare workplan for next location}

Cone penetrometer technology is at least 50 years old. The technology was originally developed in the Netherlands for foundation design. The technology has evolved since then and is currently used in environmental remediation, such as field screening. The advantage of this technology is that it provides continuous measurements in-situ. The cone

penetrometer is capable of taking water samples (1 1iter). Primary cone penetrometer measurements are sleeve friction, tip stress and pore pressure. ARA has penetrated soil depths of 150 feet average and a maximum of 300 feet.

The Hanford cone penetrometer is unique in that guide tubes support the rod (for buckling purposes) and the range of materials strength is wide. The tip stress averages for sludge simulant testing was around 15 psi while the saltcake simulant testing was between 6,000 to 10,000 psi. The basic layout of the skid includes the control room with workbenches and the data acquisition room and a hydraulic area. The skid contains two exits and a door between the control room and hydraulic area. The control room is enclosed while the hydraulic area is open.

The hydraulic rams will be located around the center of the skid. The skid will weigh between 15 and 25 tons, unballasted. Ballasting weight will be placed on the skid. Steel ballast will weigh around 2,000 lbs. Lead encased in steel ballast were discussed but rejected in the meeting since these ballast would be considered mixed waste, if contaminated. The skid is 8 feet maximum off the ground.

The safety envelop of the cone penetrometer will be 1 imited through the computer through force limitations, the bottom detection system and the length of the push rod. The force limitations will depend on the force required to penetrate the material. A maximum of 40 feet of guide tube will be used to support the push rod. The clamps on the rods will automatically keep the guide tube and push rod from dropping, similar to a foot clamp. Two size guide tubes will be implemented. The sizes are 3.5 inch $O D$ and 6 inch $O D$ guide tubes. For a 4 inch riser, the 20 inch long guide tubes will roughly weigh 18 lbs while for 12 inch riser or larger, the guide tubes will weigh around 130 lbs. The guide tube use ACME threads and push rod use taper threads. These are locked in place with a pipe wrench. The thread design may be changed since ARA will be manufacturing the push rod and guide tube. The cone penetrometer probe will use no brass (material compatibility) thermistors and is spark resistance since the probe and rod and guide tube are manufactured from austenitic stainless steel. Depth is measured through the displacement of cylinders through linear transducers. 
The support trailer will have a goose neck and is roughly 28 feet in

length. The hydraulic pump, decontamination unit, diesel electrical generator, and water storage (100 gallons at 130F) are located on the support trailer. The unit will be within a 75 foot radius of the skid. The unit is considered to be off the tank if it is located 20 feet away from the tank. DST has a dome limit of 50 tons (temporary loading) and SST have a dome loading of 100 tons maximum. The unit will be operate up to 4 days of continuous run. The unit will weigh less than 15,000 ibs, and can be haul from its location with a 1 ton pick up truck. The diesel generator will be a $100 \mathrm{hp}$ generator.

The cone penetrometer instrumentation is being designed to be explosion proof. The main instrumentation will limit energy which can be transmitted. The magnetic bottom detection is considered an energy storage unit (coil) and will be encapsulated. The housing will be explosion proof. The load cells are considered a wheatstone bridge and will have safety barriers located on the top. The neutron probe is not considered intrinsically safe but it is contained within an explosion proof enclosure. A special cable has been used to dissipate static charge. The issue of UL testing was discussed. UL testing consists of testing the unit in a hydrogen chamber and detonating it. The cost is between $\$ 15,000-\$ 20000$ and takes up to 4 weeks. OSHA permits that the unit can be documented (analyzed) to prove it is explosion proof. The latter method has been chosen. Jim Bussell will provide safety barrier manufacturers to ARA. The unit will be grounded using 2 to 3 grounds at 2 risers.

The moisture probe is deployed with a californium 252 source. This source is contained in a shielded containers. The source is installed in the moisture probe prior to insertion into the push rod cavity. Prior to entry, the moisture probe is calibrated in a cadmium lined unit. The unit reads at every inch for 12 seconds. Critical moisture content measurement is $20 \%$ and can be measured within $3 \%$.

Decontamination of the unit is accomplished with spray wash system which discharges water into the tank. A discussion occurred on collecting the water inside another tank. This concept would require the use of shielded hoses and tanks.

The final design review will occur on January, 1996. Attached are the slides used during the presentation. 


\begin{tabular}{|l|l|l|}
\hline \multirow{2}{*}{ REVIEW COMMENT RECORD (RCR) } & $\begin{array}{c}1 . \text { Date } \\
\text { Sept. 6, } 1995\end{array}$ \\
\cline { 2 - 3 } & 3. Project No. & 4. Page \\
\hline
\end{tabular}

5. Document Munber(s)/Title(s)
Cone Penetrometer Preliminary Design
Review

\begin{tabular}{|l|l|}
\hline $\begin{array}{l}\text { 6. Progrem/Project/ } \\
\text { Building Number } \\
\text { Cone } \\
\text { Penetrometer }\end{array}$ & $\begin{array}{l}\text { 7. Reviewer } \\
\text { L.S. Krogsrud }\end{array}$ \\
\hline
\end{tabular}

8. Organization/Group
TWRS/NSS

9. Location/Phone

$2751 / 2-2302$

17. Comment Submittal Approval:

Organization Manager (Optional)
10. Agreenent with indicated comnent disposition(s)

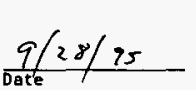

Leftogeral Reviewer/Point of contact ne pace
11. CLOSEO

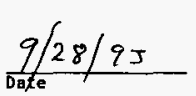

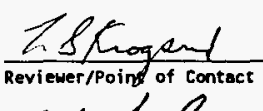

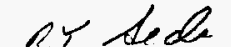

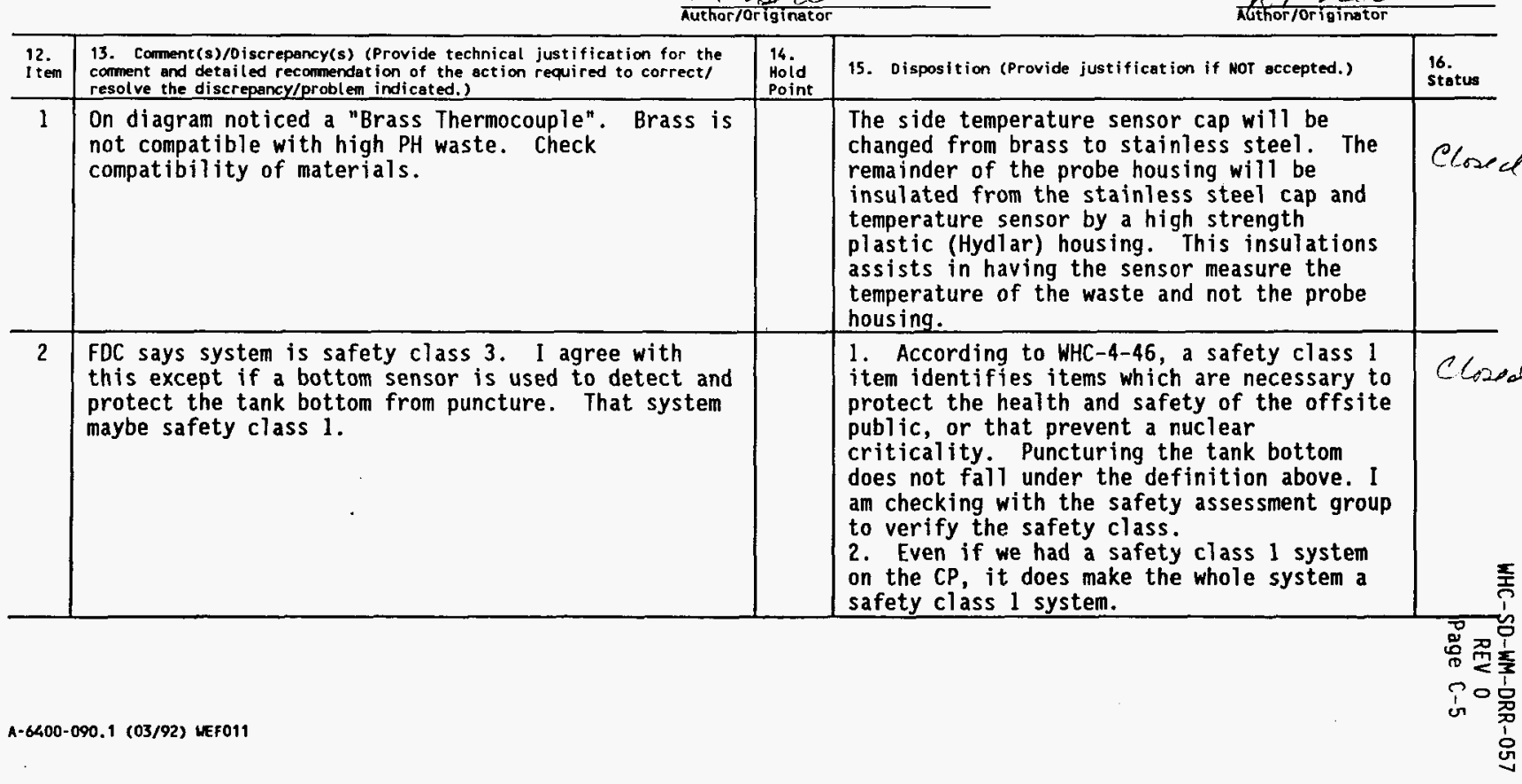




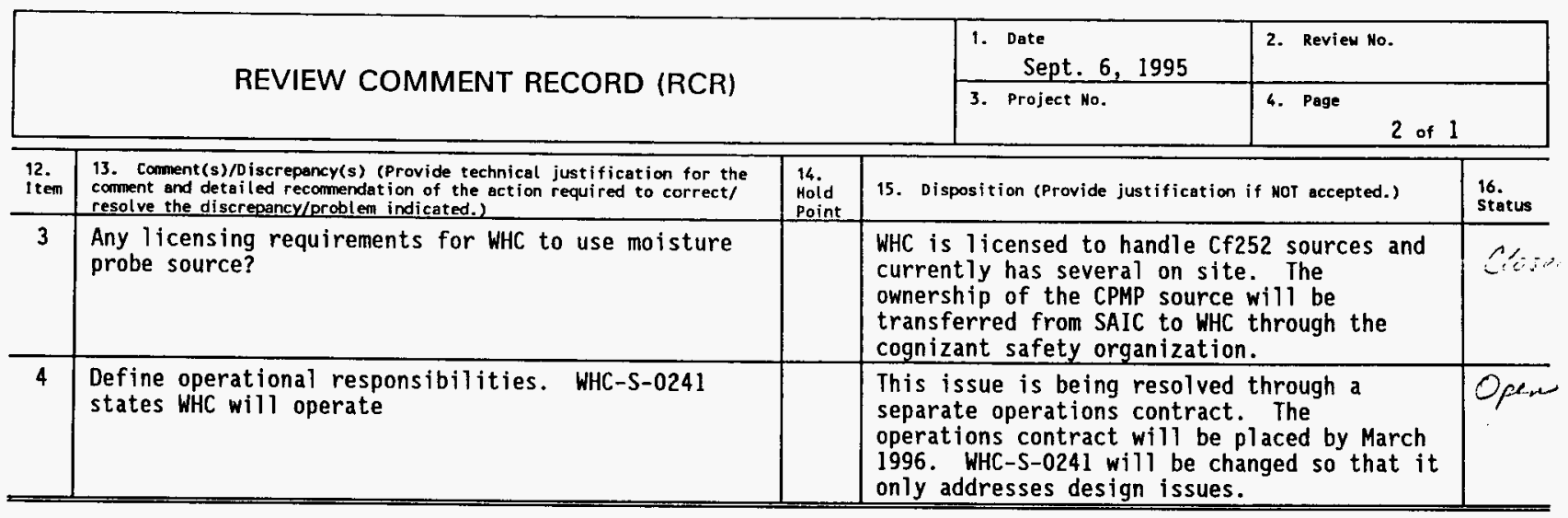




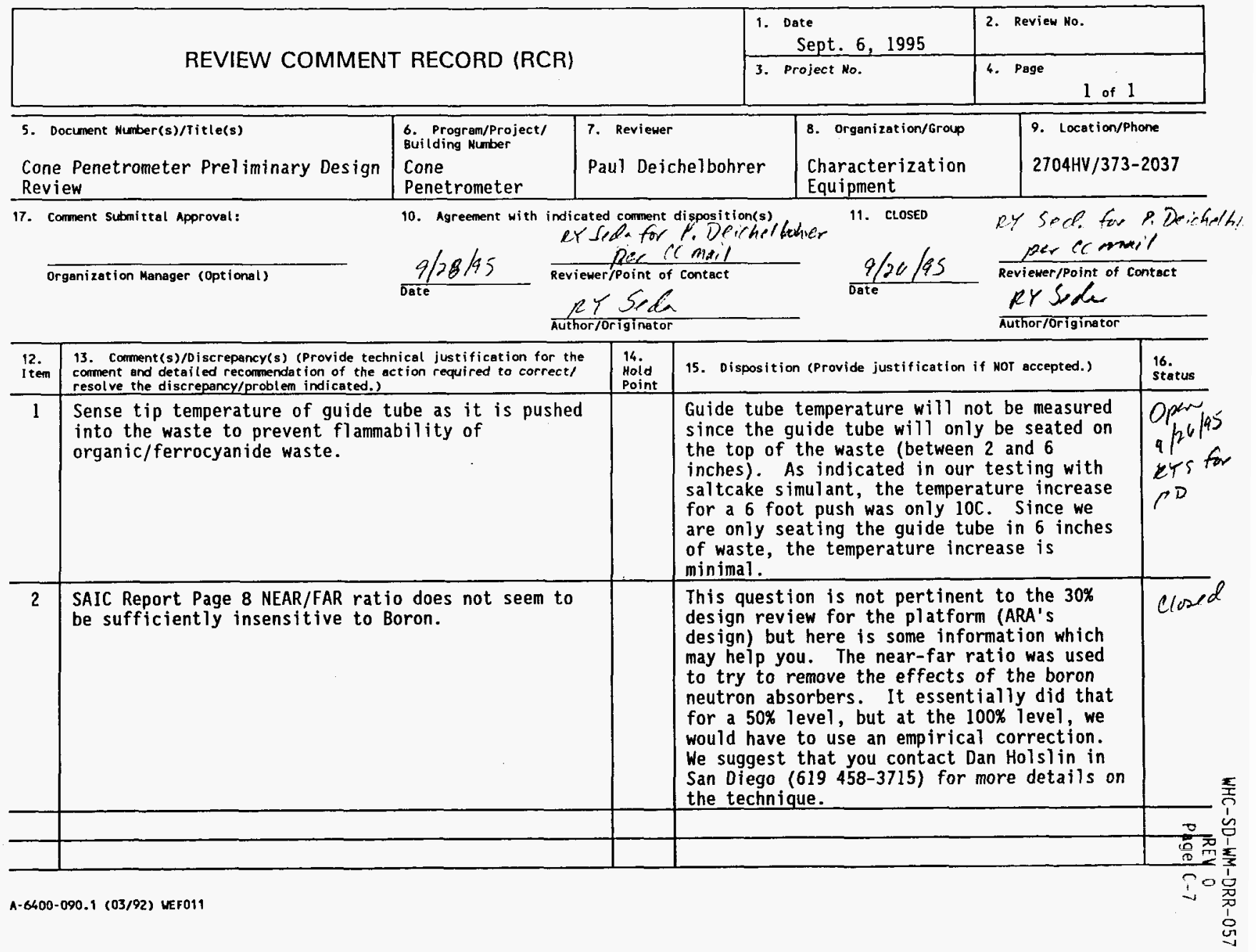




\section{REVIEW COMMENT RECORD (RCR)}

1. Date
Sept. 6, 1995

3. Project No.
2. Review Ho.

4. Page

\section{Document Number(s)/ritle(s)}

Cone Penetrometer Preliminary Design Review

17. Comment Submittal Approval:

Organization Manager (Optional)

6. Program/Project/ Building Number

Cone Penetrometer

10. Agreement with indicated comment disposition(s)

$$
9125 / 95
$$$$
\text { Date }
$$

7. Reviewer
JH Bussell

$$
\text { Rr Seen for }
$$$$
\text { TH Bussell per CCmail }
$$
Reviewer/Point of Contact

$$
\text { ey Seas }
$$

\begin{tabular}{|c|c|c|c|c|}
\hline \multirow[b]{2}{*}{$\begin{array}{l}12 . \\
\text { Item }\end{array}$} & \multirow[b]{2}{*}{$\begin{array}{l}\text { 13. Comment (s)/Discrepancy(s) (Provide technical justification for the } \\
\text { comment and detailed recommendation of the action required to correct/ } \\
\text { resolve the discrepancy/problem indicated.) }\end{array}$} & riginator & \multicolumn{2}{|l|}{$\frac{2}{\text { Author/originator }}$} \\
\hline & & $\begin{array}{l}14 . \\
\text { Hoid } \\
\text { Point }\end{array}$ & 15. Disposition (Provide justification if NOT accepted.) & $\begin{array}{l}16 . \\
\text { Status }\end{array}$ \\
\hline 1 & $\begin{array}{l}\text { LEL \& Oxygen alarm trips should be hardwired and not } \\
\text { dependent on the computer to actuate required } \\
\text { actuation. }\end{array}$ & & $\begin{array}{l}\text { The LEL, } 02 \text { and gaseous vapor alarms are a } \\
\text { self contained system located in the control } \\
\text { room of the skid. As a self contained unit, } \\
\text { they will independently activate audio } \\
\text { alarms. The unit will also output a signal } \\
\text { to the DAQ system to provide a redundant } \\
\text { visual alarm along with making an entry into } \\
\text { the comment file of which alarm signaled } \\
\text { for future reference. }\end{array}$ & eCose \\
\hline & & & & \\
\hline & & & & \\
\hline & & & & \\
\hline & & & & \\
\hline & & & & \\
\hline & & & & \\
\hline & & & & \\
\hline & & & & \\
\hline & & & & \\
\hline cunn & $90.1(03 / 92)$ WEF011 & & & $\stackrel{\Gamma}{\infty}$ \\
\hline
\end{tabular}

1 of 1 


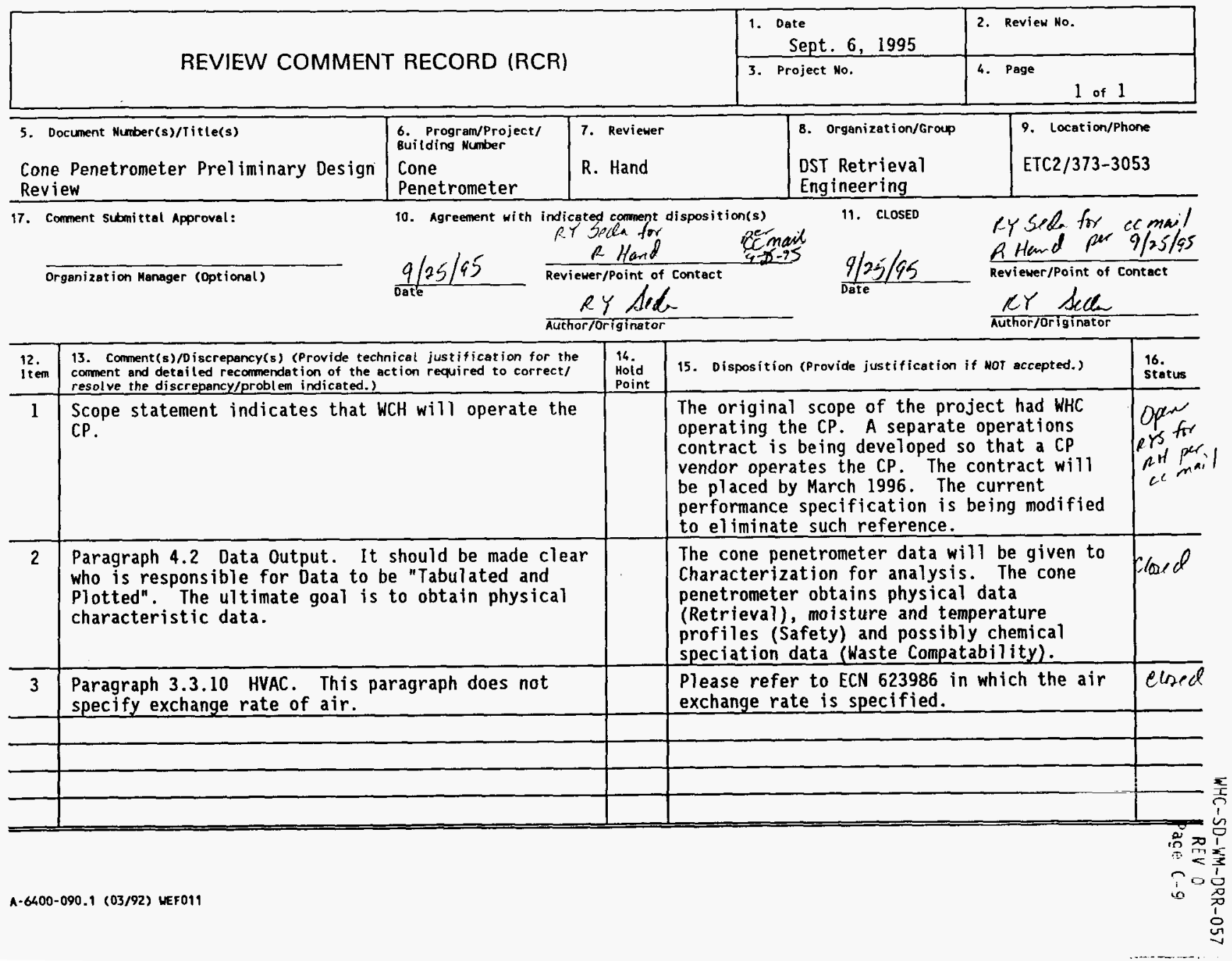




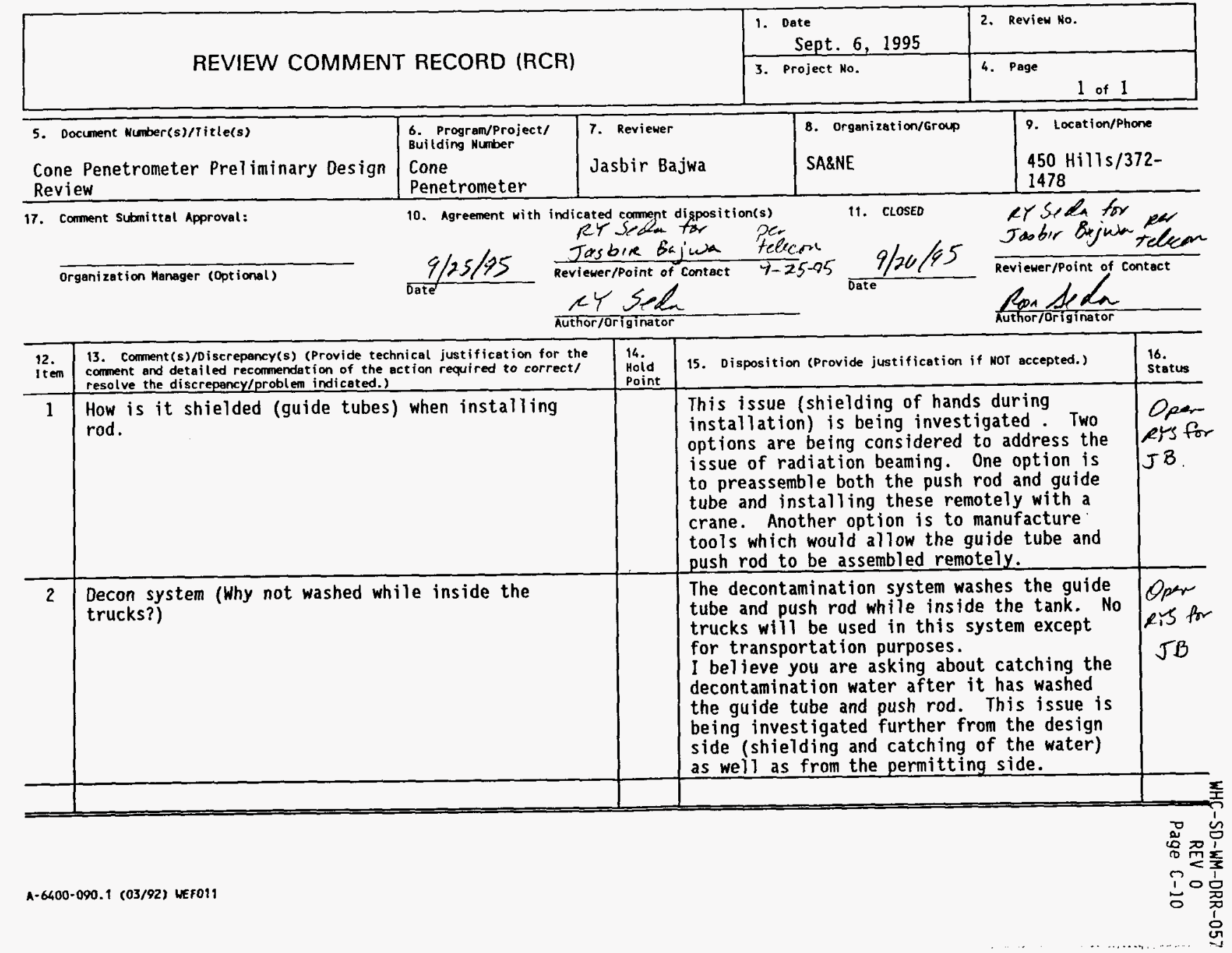


REVIEW COMMENT RECORD (RCR)

9. Date
Sept. 6, 1995
3. Project No.

3. Project No.
2. Revien No.

4. Page

5. Document Mumber(s)/Title(s)
Cone Penetrometer Preliminary Design
Review

17. Comment Submittal Approval:

Organization Manager (Optional)
6. Program/Project/ Building Number

Cone

Penetrometer

\begin{tabular}{|l|l|}
$\begin{array}{l}\text { 7. Reviewer } \\
\text { K.E. Kane }\end{array}$ & $\begin{array}{l}\text { 8. Organizetion/Group } \\
\text { CSSO/Safety Rad } \\
\text { Control }\end{array}$ \\
\hline
\end{tabular}

indicated comment, disposition(s) RYsede for pertelem
$926-95 \quad$ i. Kane $926-45$$$
926-95
$$
Date
11. ClOSED

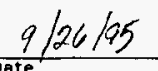
$\frac{c \text {, }}{\text { Reviewer/Point of contact }}$ eY $5, d_{a}$ Author/originator

1 of 1

9. Location/Phone

$2704 \mathrm{HV} / 6-8387$

RY sede for JE kianc po tola.

Reviewer/Point of Contact

RY Sede Author/originator

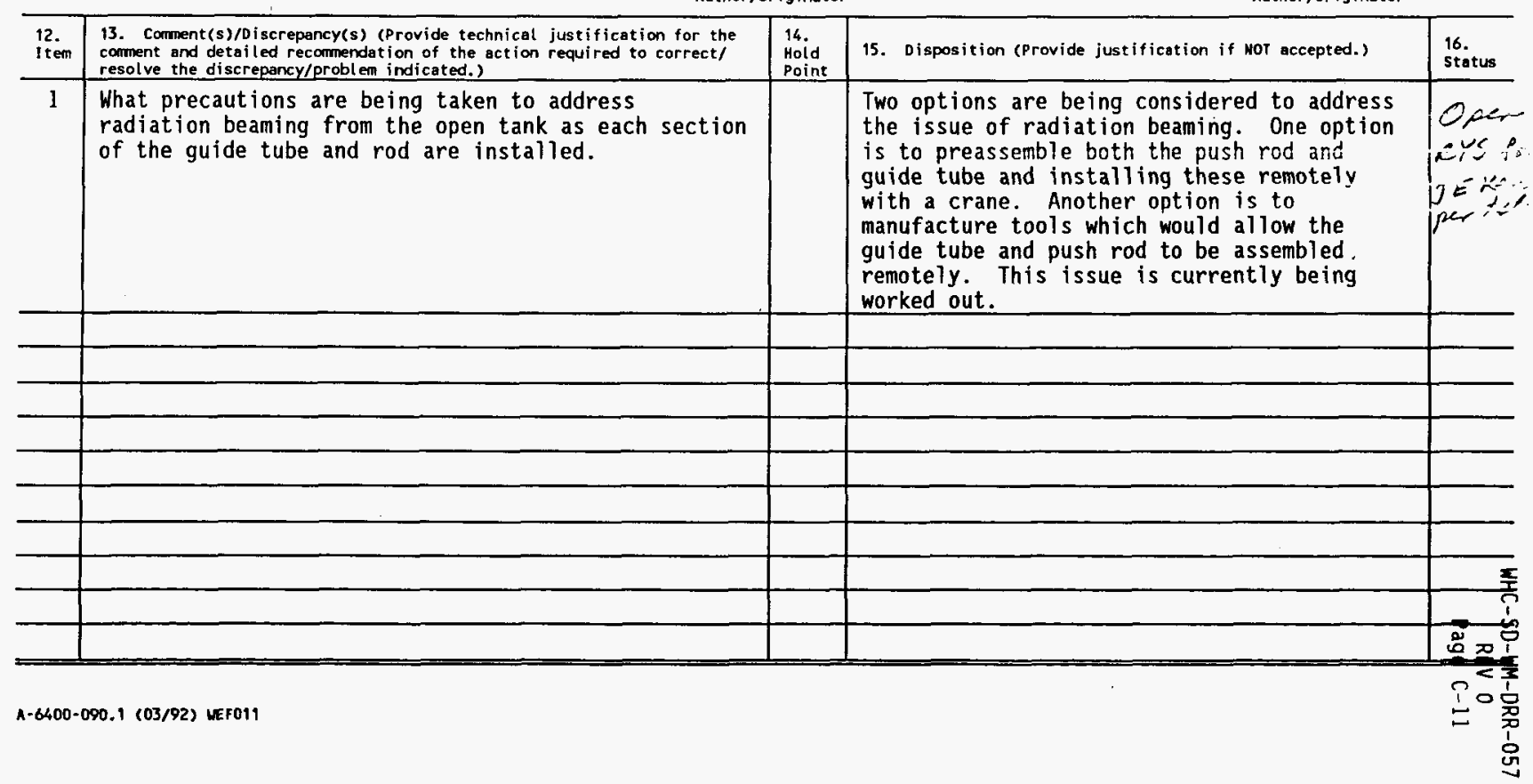




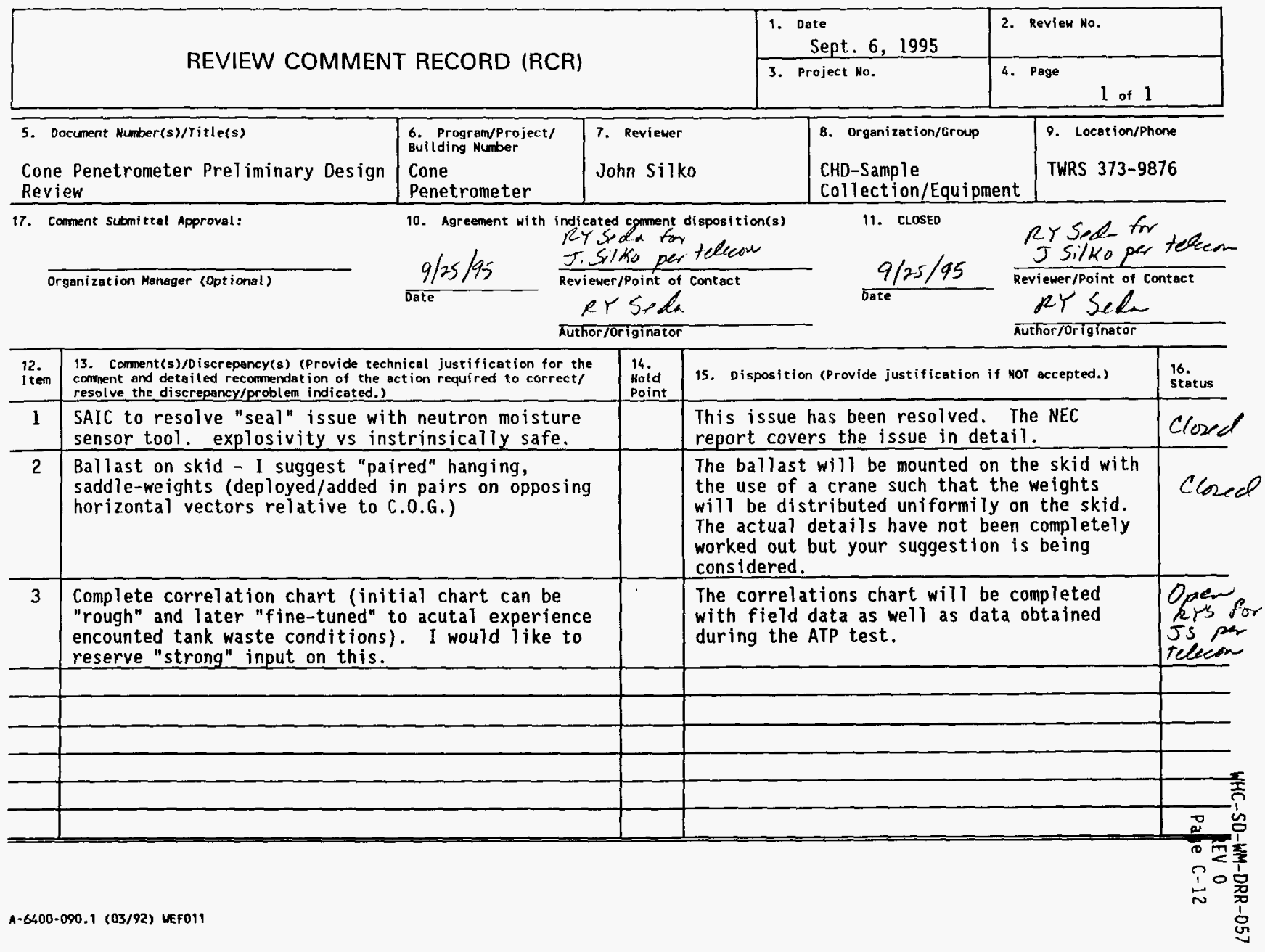




\begin{tabular}{|c|c|c|}
\hline PEYIFWI COMMENT D & $\begin{array}{l}\text { 1. Date } \\
\text { Sept. 6, } 6,1995 \\
\end{array}$ & 2. Review No. \\
\hline REVIEV CUIVIVIENI RELUKU (RCR) & 3. Project Ho. & 4. Page 1 of 1 \\
\hline
\end{tabular}

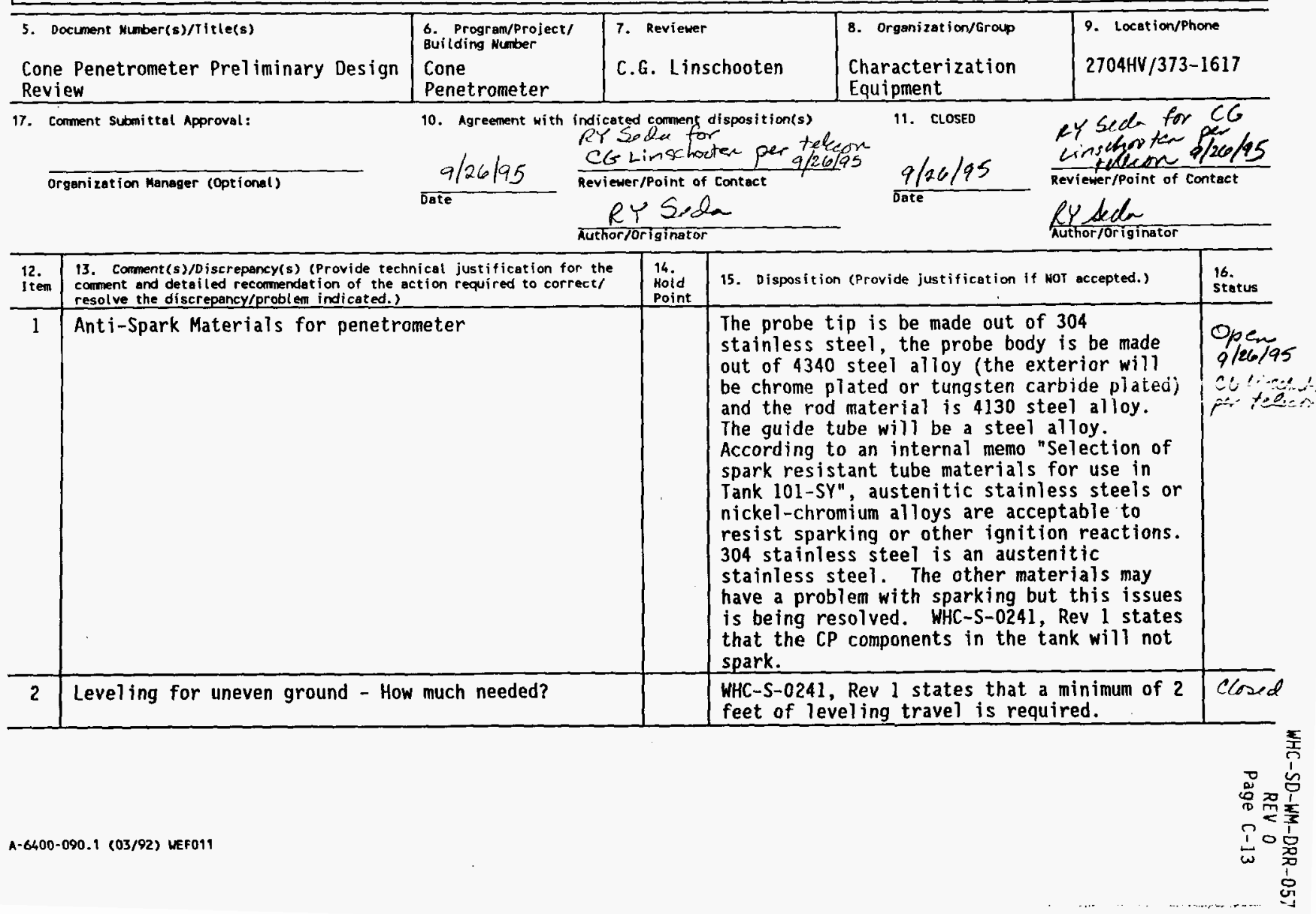




\begin{tabular}{|c|c|c|c|c|c|}
\hline \multirow{2}{*}{\multicolumn{3}{|c|}{ REVIEW COMMENT RECORD (RCR) }} & $\begin{array}{l}\text { 1. Date } \\
\text { Sept. 6, } 1995 \\
\end{array}$ & \multicolumn{2}{|l|}{ 2. Revien No. } \\
\hline & & & 3. Project No. & \multicolumn{2}{|c|}{2 of 1} \\
\hline $\begin{array}{l}12 . \\
\text { item }\end{array}$ & $\begin{array}{l}\text { 13. Comment(s)/Discrepency(s) (Provide technical justification for the } \\
\text { comment and detailed recommendation of the action required to correct/ } \\
\text { resolve the discrepancy/problem indicated.) }\end{array}$ & $\begin{array}{l}14 . \\
\text { Hoid } \\
\text { Point }\end{array}$ & \multicolumn{2}{|c|}{ 15. Disposition (Provide justification if NOT accepted.) } & $\begin{array}{l}16 . \\
\text { status }\end{array}$ \\
\hline 3 & $\begin{array}{l}\text { How much clearance is there between the outside of } \\
\text { the penetrometer tube and the inside of the guide } \\
\text { tube? }\end{array}$ & & \multicolumn{2}{|c|}{$\begin{array}{l}\text { Both sets of guide tubes will have an ID of } \\
2.25 \text { inches. The rods will be most likely a } \\
1.75 \text { inch OD rod and the probe will have a } \\
2.0 \text { inch OD. A } 2.0 \text { inch OD rod is being } \\
\text { considered but is not currently in the plan. }\end{array}$} & $\cos \theta$ \\
\hline
\end{tabular}




\begin{tabular}{|c|l|l|l|}
\hline \multirow{2}{*}{ REVIEW COMMENT RECORD (RCR) } & $\begin{array}{c}\text { 1. Date } \\
\text { Sept. 6, 1995 }\end{array}$ & \begin{tabular}{l}
2. Review No. \\
\cline { 2 - 3 }
\end{tabular} & $\begin{array}{l}3 . \text { Project No. Page } \\
1\end{array}$ \\
\hline
\end{tabular}

5. Document Mumber(s)/Title(s)
Cone Penetrometer Preliminary Design
Review

17. Comment submittal approval:

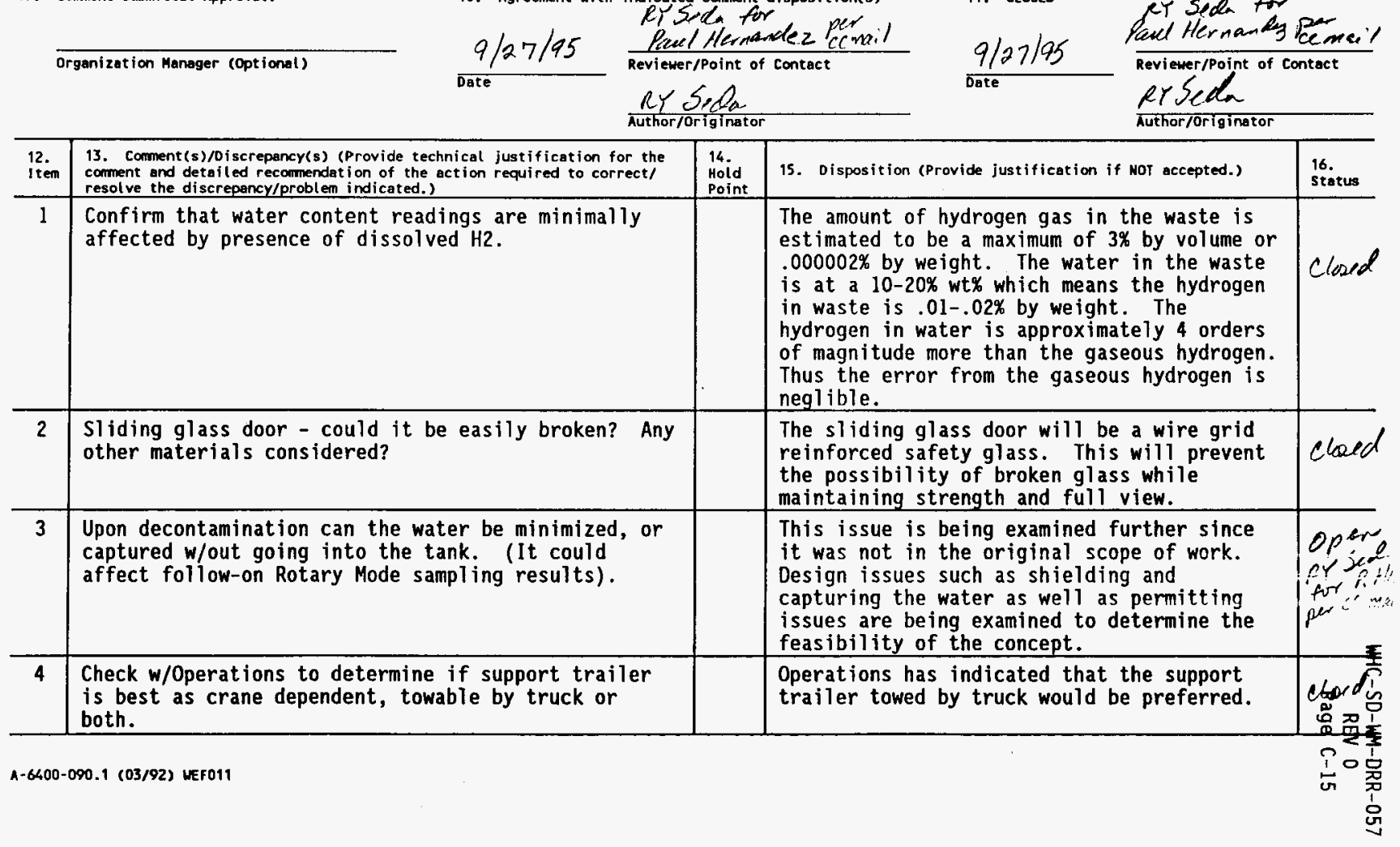

\begin{tabular}{|l|l|l|}
\hline $\begin{array}{l}\text { 6. Program/Project/ } \\
\text { Building Number } \\
\text { Cone } \\
\text { Penetrometer }\end{array}$ & $\begin{array}{l}\text { 7. Reviewer } \\
\text { Paul Hernandez }\end{array}$ & $\begin{array}{l}\text { 8. Organization/Group } \\
\text { RL-CHD }\end{array}$ \\
\hline
\end{tabular}

Penetrometer

10. Agreement with indicated comment disposition(s)

10. Agreement with indicated comment dis

Raul tlernandez Permail

RY S.la

Athor/Originator
11. CLOSED

1 of 1

9. Location/Phone

$376-2209$

RT Seda for

$9 / 27 / 95$

Date Pavel Hernandy per Reviewer/Point of contact ey Sech

Author/originator 


\begin{tabular}{|c|c|c|c|c|c|}
\hline \multirow{2}{*}{\multicolumn{3}{|c|}{ REVIEW COMMENT RECORD (RCR) }} & $\begin{array}{l}\text { 1. Date } \\
\text { Sept. 6, } 1995\end{array}$ & \multicolumn{2}{|l|}{ 2. Review No. } \\
\hline & & & 3. Project No. & 4. Page & \\
\hline $\begin{array}{ll}12 . \\
\text { Item }\end{array}$ & $\begin{array}{l}\text { 13. Comment(s)/Discrepancy(s) (Provide technical justification for the } \\
\text { comment and detai i led recomnendation of the action required to correct/ } \\
\text { resolve the discrepancy/problem indicated.) }\end{array}$ & $\begin{array}{l}14 . \\
\text { Hoid } \\
\text { Point }\end{array}$ & \multicolumn{2}{|c|}{ 15. Disposition (Provide Justification if Nor accepted.) } & $\begin{array}{l}16 . \\
\text { status }\end{array}$ \\
\hline 5 & $\begin{array}{l}\text { Verify w/HAMTECH union that outside vendors will be } \\
\text { "allowed" to operate the CPT. }\end{array}$ & & \multicolumn{2}{|c|}{$\begin{array}{l}\text { This issue is being resolved through a } \\
\text { separate operations contract. The } \\
\text { operations contract will be placed by March } \\
\text { 1996. }\end{array}$} & $\begin{array}{l}\text { Open } \\
\text { Rys for } \\
\text { pHitid }\end{array}$ \\
\hline 6 & $\begin{array}{l}\text { Verify that outside vendors will not be required to } \\
\text { comply with lengthy, elaborate procedures to operate } \\
\text { CPT in tank farms. }\end{array}$ & & \multicolumn{2}{|c|}{$\begin{array}{l}\text { This issue is being resolved through a } \\
\text { separate operations contract. The } \\
\text { operations contract will be placed by March } \\
\text { 1996. }\end{array}$} & $\begin{array}{l}\text { oper } \\
\text { pis for } \\
\text { priper per }\end{array}$ \\
\hline & & & & \\
\hline & & & & \\
\hline & & & & \\
\hline & & & \multicolumn{2}{|c|}{ 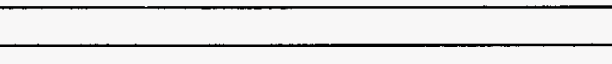 } & \\
\hline & & & & \\
\hline & & & \multirow{2}{*}{\multicolumn{2}{|c|}{ 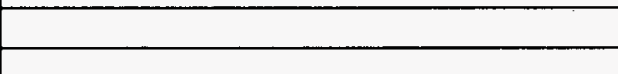 }} & \\
\hline & & & & & \\
\hline & & & & \\
\hline & & & & & \\
\hline
\end{tabular}




\begin{tabular}{|c|c|c|}
\hline & $\begin{array}{l}\text { 1. Date } \\
\text { Sept. 6, } 1995\end{array}$ & 2. Review No. \\
\hline REVIEW COMMENT RECORD (RCR) & 3. Project No. & 4. Page \\
\hline
\end{tabular}

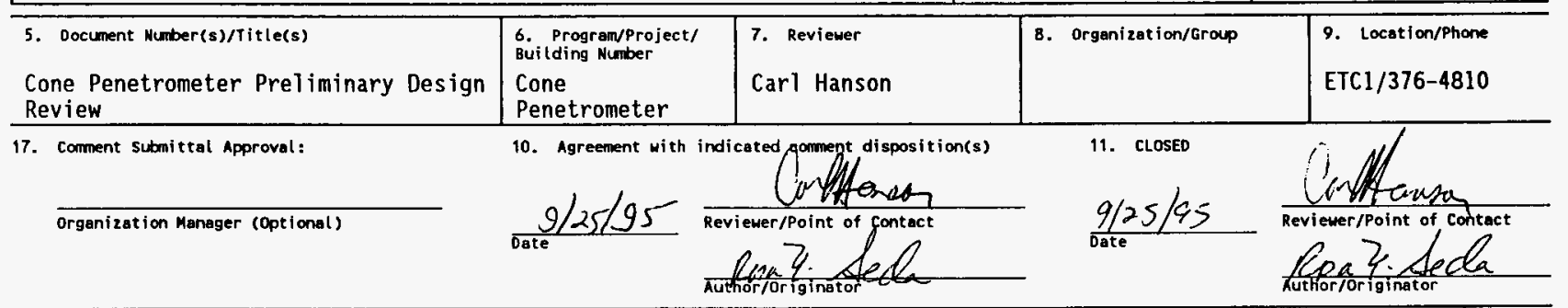

\begin{tabular}{|c|c|c|c|c|}
\hline $\begin{array}{l}12 . \\
\text { item }\end{array}$ & $\begin{array}{l}\text { 13. Comment(s)/Discrepancy(s) (Provide technical justification for the } \\
\text { comment and detailed recommendation of the act ion required to correct/ } \\
\text { resolve the discrepancy/problem indicated.) }\end{array}$ & $\begin{array}{l}\text { 14. } \\
\text { Hold } \\
\text { Point }\end{array}$ & 15. Disposition (Provide justification if NOT accepted.) & $\begin{array}{l}16 . \\
\text { Status }\end{array}$ \\
\hline 1 & $\begin{array}{l}\text { Decon system. .Discussed using "Drum Pick UP" of } \\
\text { waste water. Need to fina] ize decontamination } \\
\text { method and give to ARA. }\end{array}$ & & $\begin{array}{l}\text { This issue is being investigated from the } \\
\text { design side (shielding and catching of the } \\
\text { water) as well as from the permitting side. }\end{array}$ & $\begin{array}{l}\text { OPEN } \\
\text { CLPT } \\
Q / 2 \text { is/a. }\end{array}$ \\
\hline 2 & $\begin{array}{l}\text { Need to identify size of fuel tank for diesel } \\
\text { general (Is } 4 \text { days adequate?) }\end{array}$ & & $\begin{array}{l}\text { The performance specification states that } \\
\text { the CP sensors will be in the tank for a } \\
\text { period of } 2 \text { weeks without degradation. This } \\
\text { is to accommodate for any } \\
\text { maintenance/repairs required. The actual } \\
\text { operation time for the full tank scan is } \\
\text { probably in the order of } 1 \text { or } 2 \text { days. A } 4 \\
\text { day supply is a conservative estimate for } \\
\text { fuel tank size. }\end{array}$ & $\begin{array}{l}\text { coosen } \\
\text { crat } \\
9 / 25 / 93\end{array}$ \\
\hline 3 & $\begin{array}{l}\text { Investigate if there are any permitting issues } \\
\text { w/this diesel generator. }\end{array}$ & & $\begin{array}{l}\text { No permitting issues exist for portable } \\
\text { generator of } 500 \mathrm{hp} \text { or less. }\end{array}$ & $\begin{array}{l}\text { coosen } \\
\text { ctity } \\
9125)^{4}\end{array}$ \\
\hline 4 & $\begin{array}{l}\text { Investigate shielding reqd to protect workers from } \\
\text { "Hand Dose" while inserting rod and guide tube. }\end{array}$ & & $\begin{array}{l}\text { This issue is being investigated. Two } \\
\text { options are being considered to address the } \\
\text { issue of radiation beaming. One option is } \\
\text { to preassemble both the push rod and guide } \\
\text { tube and installing these remotely with a } \\
\text { crane. Another option is to manufacture } \\
\text { tools which would allow the guide tube and } \\
\text { push rod to be assembled remotely. }\end{array}$ & Oper \\
\hline
\end{tabular}




\begin{tabular}{|c|c|c|}
\hline & $\begin{array}{l}\text { 1. Date } \\
\quad \text { Sept. 6, } 1995\end{array}$ & $\begin{array}{l}\text { 2. Review Ho. } \\
\text { CPq5-014 }\end{array}$ \\
\hline REVIEW COMMENT RECORD (RCR) & 3. Project Mo. & 4. Page \\
\hline
\end{tabular}

5. Document Number(s)/Title(s)

Cone Penetrometer Preliminary Design Review

\section{Comment Submitzal Approval:}

Organization Manager (Optional)

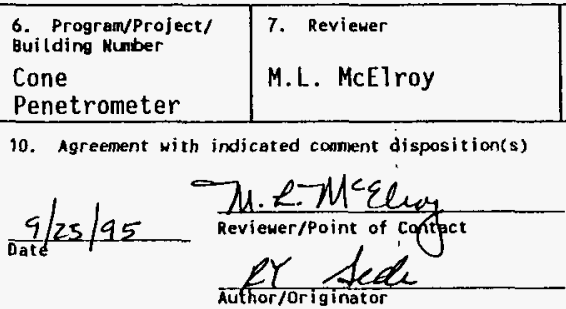

B. Organization/Group CPQA
11. CLOSEO

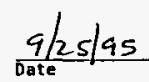

M.L.MEQRy Reviewer/Point of Gorfact Reviewer/Point of gong

Auriarinator

\begin{tabular}{|c|c|c|c|c|}
\hline $\begin{array}{l}12 . \\
\text { Itent }\end{array}$ & $\begin{array}{l}\text { 13. Comment(s)/Discrepancy(s) (Provide technical justification for the } \\
\text { comment and detailed recommendation of the action required to correct/ } \\
\text { resolve the discrepancy/problem indicated.) }\end{array}$ & $\begin{array}{l}14 . \\
\text { Hoid } \\
\text { Point }\end{array}$ & 15. Disposition (Provide justification if NOI accepted.) & $\begin{array}{l}16 . \\
\text { Status }\end{array}$ \\
\hline 1 & $\begin{array}{l}\text { Noticed that a teflon filter and brass sensor unit } \\
\text { will be used in probe design - these materials are } \\
\text { questionable when used in organic/H2 atmospheres. }\end{array}$ & & $\begin{array}{l}\text { The side temperature sensor cap will be } \\
\text { changed from brass to stainless steel. The } \\
\text { remainder of the probe housing will be } \\
\text { insulated from the stainless steel cap and } \\
\text { temperature sensor by a high strength } \\
\text { plastic (Hydlar) housing. This insulation } \\
\text { assist in having the sensor measure the } \\
\text { temperature of the waste and not the probe } \\
\text { housing. The standard pore pressure filter } \\
\text { material consist of polyethanlene (sp) } \\
\text { plastic material. The viewgraph was } \\
\text { incorrect in stating teflon. He can change } \\
\text { this to a sintered metal (stainless steel) } \\
\text { filter if required. }\end{array}$ & $C<$ \\
\hline 2 & $\begin{array}{l}\text { For the program, state permitting may be needed to } \\
\text { be addressed; i.e. EPA permits for diesel power } \\
\text { operation. }\end{array}$ & & $\begin{array}{l}\text { No permitting issues exist for portable } \\
\text { generators with less than } 500 \mathrm{hp} \text {. }\end{array}$ & \\
\hline 3 & Who or what organization will analyze the end data? & & Characterization. & \\
\hline A- 64 & $190.1(03 / 92)$ UEf011 & & & 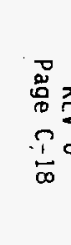 \\
\hline
\end{tabular}




\begin{tabular}{|c|c|c|}
\hline & $\begin{array}{l}\text { 1. Date } \\
\text { Sept. } 6,1995\end{array}$ & 2. Revien No. \\
\hline REVIEW COMMENT RECORD (RCR) & 3. Project No. & 4. Page \\
\hline
\end{tabular}

\begin{tabular}{|c|c|c|c|c|}
\hline $\begin{array}{l}12 . \\
\text { It em }\end{array}$ & $\begin{array}{l}\text { 13. Conment(s)/Discrepancy(s) (Provide technical justification for the } \\
\text { corment ond detoiled recormendation of the action required to correct/ } \\
\text { resolve the discrepancy/problem indicated.) }\end{array}$ & $\begin{array}{l}\text { 14. } \\
\text { Hoid } \\
\text { Point }\end{array}$ & 15. Disposition (Provide justification if NOI accepted.) & $\begin{array}{l}16 . \\
\text { Status }\end{array}$ \\
\hline 4 & $\begin{array}{l}\text { Aluminum decking is to be used - be aware that } \\
\text { cracking of welds and materials has been a problem. } \\
\text { Also, any organic spill on aluminum will cause toxic } \\
\text { fumes and deterioration of the aluminum, as per 101- } \\
\text { Sy study. }\end{array}$ & & $\begin{array}{l}\text { The skid system is designed strictly for in- } \\
\text { situ testing of the tank waste material and } \\
\text { not sampling. No tank material will be } \\
\text { retrieved with the unit and therefore } \\
\text { organic materials will not encounter the } \\
\text { decking material. The aluminum decking will } \\
\text { not experience the same loads (rotating) } \\
\text { that the core sample truck experiences. The } \\
\text { design has yet to be finalized (bolting vs } \\
\text { welding the deck on the skid) but your } \\
\text { comment is being considered. }\end{array}$ & \\
\hline & & & & \\
\hline & & & & \\
\hline
\end{tabular}




\section{REVIEW COMMENT RECORD (RCR)}

1. Date

Sept. 6, 1995

2. Revien Ho.

3. Project No.

4. Page

1 of 1

5. Document Number(s)/Jitle(s)

Cone Penetrometer Preliminary Design Review

17. Comment Subnittal Approval:

\begin{tabular}{|c|c|}
\hline $\begin{array}{l}\text { 6. Program/Project/ } \\
\text { Bui lding Nunber }\end{array}$ & 7. Reviewer \\
\hline $\begin{array}{l}\text { Cone } \\
\text { Penetrometer }\end{array}$ & \\
\hline
\end{tabular}

10. Agrement with indicated coment disposition(s)

Organization Manager (Optional)

$9-6-95$
I 721 gens Reviewer/Point of Contact
8. Organization/Group

hHC IE

11. CLOSED

0.6 .95 7202

Date

$$
\text { bate }
$$

12.
Item
comment ond detailed recommendation of the action required to correct/ comment and detailed recommendation of the action required to correct/ Hoid resolve the discrepancy/problem indicated.)

$30 \%$ Desifa Pevien

Slicle precentationeouras $a^{2} \cdot \operatorname{loc}^{-6}$

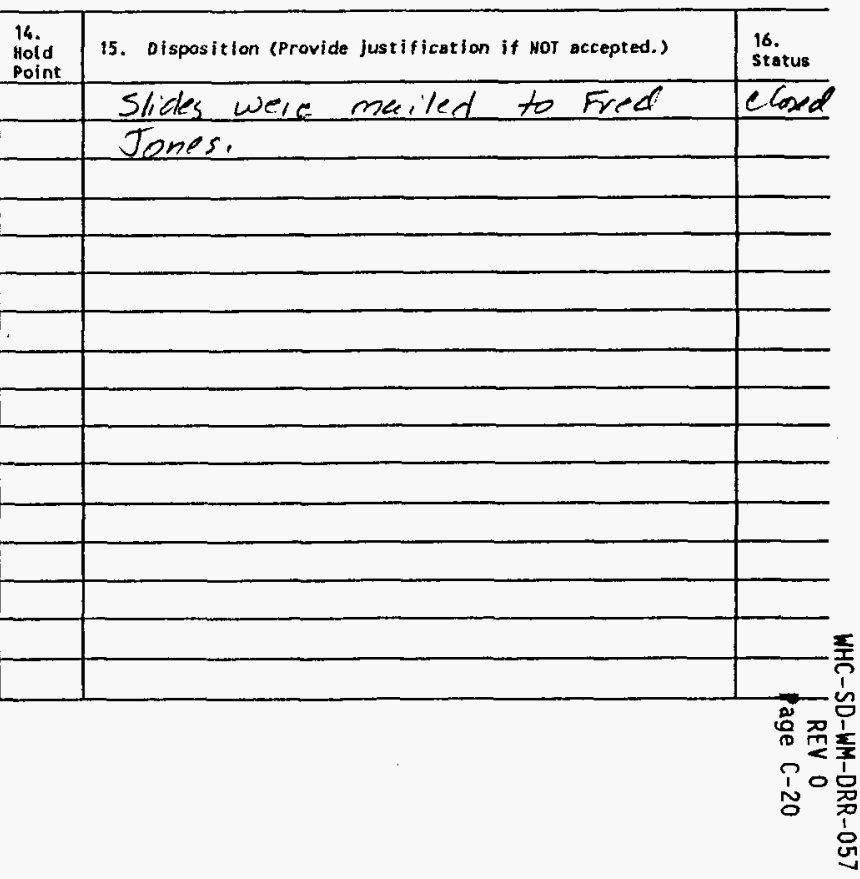




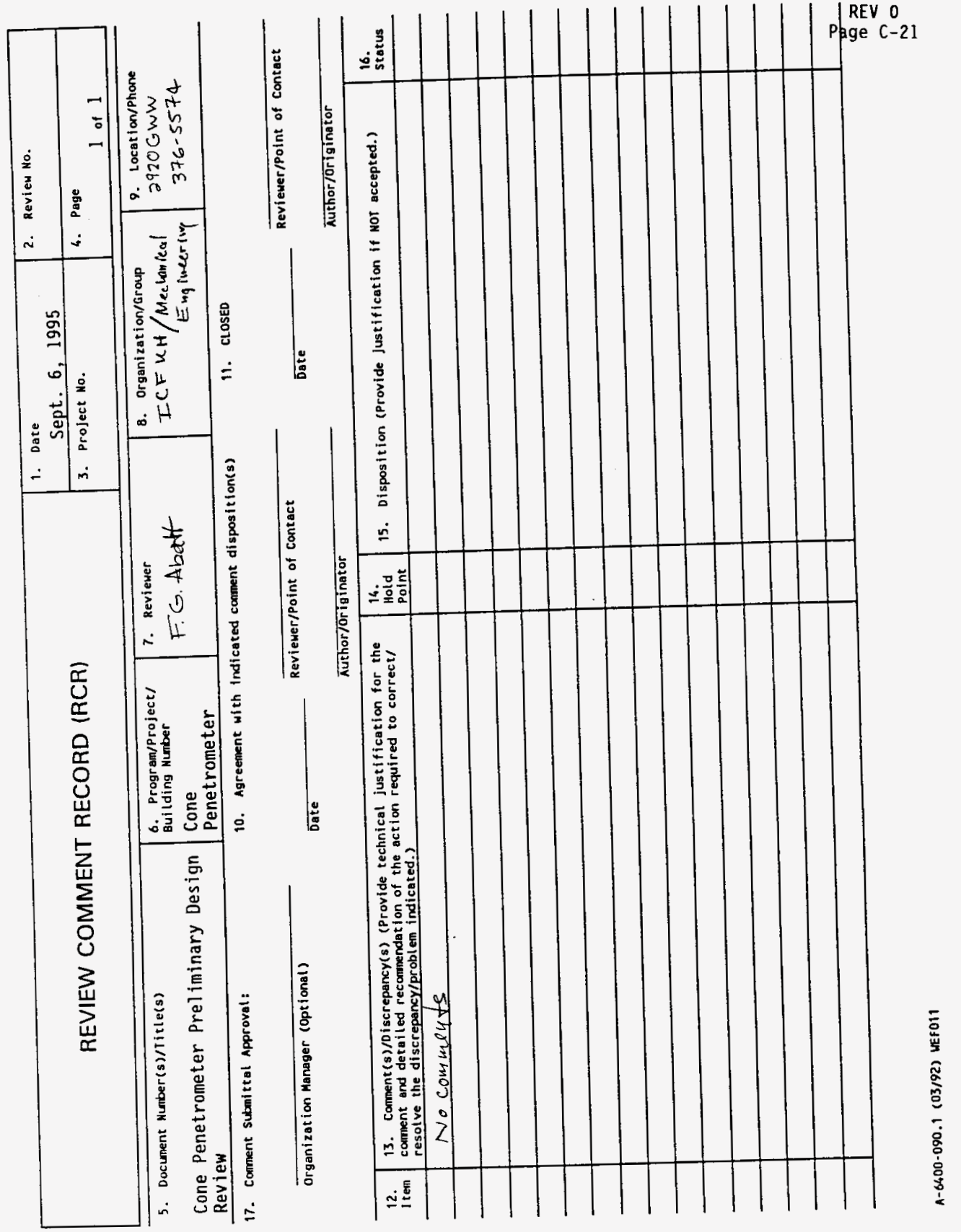




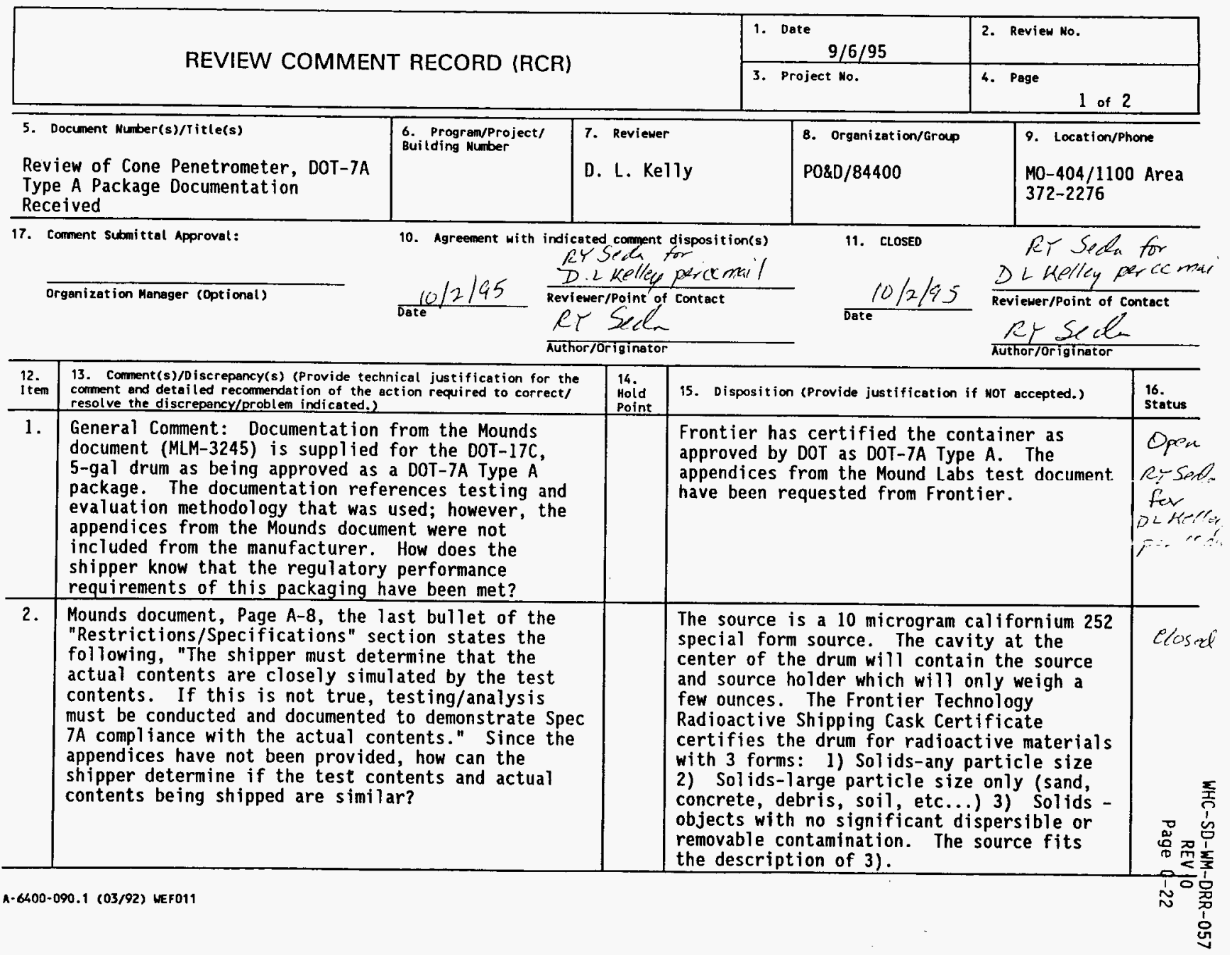




\begin{tabular}{|l|l|l|}
\hline \multirow{2}{*}{ REVIEW COMMENT RECORD (RCR) } & $\begin{array}{l}\text { 2. Date } 9 / 6 / 95 \\
\text { Review No. }\end{array}$ \\
\cline { 2 - 3 } & 3. Project No. & 4. Page 2 of 2 \\
\hline
\end{tabular}

\begin{tabular}{|c|c|c|c|c|}
\hline $\begin{array}{l}12 . \\
\text { item }\end{array}$ & $\begin{array}{l}\text { 13. Comment(s)/oiscrepancy(s) (Provide technical justification for the } \\
\text { comment and detailed recommendation of the action required to correct/ } \\
\text { resolve the discrepancy/problem indicated.) }\end{array}$ & $\begin{array}{l}\text { Meiv } \\
\text { Hoid } \\
\text { Point }\end{array}$ & 15. Disposition (Provide justification if NOT accepted.) & $\begin{array}{l}16 . \\
\text { Status } \\
\end{array}$ \\
\hline 3. & $\begin{array}{l}\text { General Comment: Upon my review of the Mounds } \\
\text { document, it was found that the actual contents used } \\
\text { for testing the DOT-17C,5-gal drum were flour, } \\
\text { fluorescein, sand, and lead. These test contents } \\
\text { differ significantly from the actual contents being } \\
\text { shipped. There is no test or evaluation } \\
\text { documentation included in the manufacturer's } \\
\text { information to support that the contents being } \\
\text { shipped would survive any of the DOr-7A Type A } \\
\text { tests. }\end{array}$ & & $\begin{array}{l}\text { As the weight of the source falls within the } \\
\text { spectrum of the weights tested, the package } \\
\text { will not be affected by the source. We are } \\
\text { not aware of any requirement that the actual } \\
\text { source be included in the shipping container } \\
\text { tests. The source transportability is } \\
\text { certified separately by DOT. }\end{array}$ & elosed \\
\hline 4. & $\begin{array}{l}\text { Drawing A50240-AA00: With the 3-4 inch head space } \\
\text { in the drum, it appears that if the drum were } \\
\text { dropped flat onto the top lid, there would be a } \\
\text { chance that the steel pipe would ram into the drum } \\
\text { lid, damaging the packaging significantly. Also, it } \\
\text { is not known how tightly the plywood/masonite } \\
\text { spacers fit around the pipe to deter shifting of } \\
\text { contents. The performance of the WEP material is } \\
\text { not known. } \\
\text { Page A-8, "Restrictions/Specifications," states: } \\
\text { The shipper must assure that the contents are } \\
\text { securely fastened and positioned within the package. } \\
\text { Each shipper must assure that the radiation level at } \\
\text { the surface of the package will not increase by more } \\
\text { than } 20 \text { percent. }\end{array}$ & & $\begin{array}{l}\text { The pipe shown in Drawing A50250-AAO0 will } \\
\text { not ram the upper lid. This pipe is fixed } \\
\text { in the drum with the WEP cast in place, } \\
\text { which also holds the spacers in place. The } \\
\text { pipe should remain in place. The WEP } \\
\text { material survived the drop test. }\end{array}$ & closed \\
\hline
\end{tabular}


Author: Donna L Relly at - WHC3

Thank you for getting back to me. I'm sorry that it has taken me quite some time to get back to you--between classes and travel, I just haven't been here.

The RCR is acceptable to me, and I have no further comments. As long as you receive the requested information from Frontier, and are satisfied with their evaluation/test documentation, and have this documentation for your files, you ghould be covered.

Donna

Subject: RCR

Reply separator

Author: Rosa Y Seda at -WHC131

Date: $9 / 21 / 953: 56$ PM

Donna, the attached RCR is for the $30 \%$ design review for the cone penetrometer. Your comments were not necessarily pertinent to the design review (it only covered the rig, not the moisture probe... we have already done a 908 design review on the moisture probe) BUT I went ahead and asked SAIC to resolve your comment. Attached is a copy of the RCR with your comments and their resolution. please review the RCR and sign-off if you agree with them. If you are not satisfied, we will set up a meeting with you, Characterization Equipment Development and SAIC (they are here about twice a month) to resolve the issues once and for all.

Rosa 